\title{
A novel definition and treatment of hyperinflammation in COVID-19 based on purinergic signalling
}

\author{
Djo Hasan ${ }^{1}$ (D) Atsuko Shono ${ }^{2}$. Coenraad K. van Kalken ${ }^{3}$. Peter J. van der Spek ${ }^{4}$ (D) \\ Eric P. Krenning ${ }^{5} \cdot$ Toru Kotani $^{2}$
}

Received: 20 January 2021 / Accepted: 18 July 2021 / Published online: 10 November 2021

(C) The Author(s) 2021

\begin{abstract}
Hyperinflammation plays an important role in severe and critical COVID-19. Using inconsistent criteria, many researchers define hyperinflammation as a form of very severe inflammation with cytokine storm. Therefore, COVID-19 patients are treated with anti-inflammatory drugs. These drugs appear to be less efficacious than expected and are sometimes accompanied by serious adverse effects. SARS-CoV-2 promotes cellular ATP release. Increased levels of extracellular ATP activate the purinergic receptors of the immune cells initiating the physiologic pro-inflammatory immune response. Persisting viral infection drives the ATP release even further leading to the activation of the P2X7 purinergic receptors (P2X7Rs) and a severe yet physiologic inflammation. Disease progression promotes prolonged vigorous activation of the P2X7R causing cell death and uncontrolled ATP release leading to cytokine storm and desensitisation of all other purinergic receptors of the immune cells. This results in immune paralysis with co-infections or secondary infections. We refer to this pathologic condition as hyperinflammation. The readily available and affordable P2X7R antagonist lidocaine can abrogate hyperinflammation and restore the normal immune function. The issue is that the half-maximal effective concentration for P2X7R inhibition of lidocaine is much higher than the maximal tolerable plasma concentration where adverse effects start to develop. To overcome this, we selectively inhibit the P2X7Rs of the immune cells of the lymphatic system inducing clonal expansion of Tregs in local lymph nodes. Subsequently, these Tregs migrate throughout the body exerting anti-inflammatory activities suppressing systemic and (distant) local hyperinflammation. We illustrate this with six critically ill COVID-19 patients treated with lidocaine.
\end{abstract}

Keywords COVID-19 $\cdot$ P2X7 receptor antagonist $\cdot$ Lidocaine base $\cdot$ Hyperinflammation $\cdot$ Cytokine storm $\cdot$ Immune paralysis

Djo Hasan

djohasan@gmail.com

Atsuko Shono

atsukos@med.showa-u.ac.jp

Peter J. van der Spek

p.vanderspek@erasmusmc.nl

Toru Kotani

trkotani@med.showa-u.ac.jp

Kasterlee, Belgium

2 Department of Anaesthesiology and Critical Care Medicine, School of Medicine, Showa University, Tokyo 142-8666, Japan

3 Hoorn, The Netherlands

4 Department of Pathology \& Clinical Bioinformatics, Erasmus MC, Erasmus Universiteit Rotterdam, 3015

CE Rotterdam, The Netherlands

5 Rotterdam, The Netherlands

\section{Introduction}

Hyperinflammation and acute respiratory distress syndrome (ARDS) caused by coronavirus disease 2019 (COVID-19) have become the world's number 1 challenge. The exponential pattern in the number of severe cases in the second and third waves of the SARS-CoV-2 pandemic has shown to reach nations' maximum ICU capacities in weeks rather than months after outbreak of the disease irrespective of rigorous population-based preventive measures. In a recently published systematic review, the case fatality rates in patients in the ICU across 7 countries vary between 14.9 and $66.7 \%$, while the case fatality rates among those who required mechanical ventilation vary between 16.7 and $97.0 \%$ [1]. In addition, the case fatality rate in a cohort of 1035 critically ill COVID-19 patients requiring extracorporeal membrane oxygenation (ECMO, artificial lungs) is alarmingly high (37.4\%) [2]. 
The clinical manifestations of severe COVID-19 consist of pneumonia with dyspnoea and hyperinflammation. Hyperinflammation is thought to be the basis of the development of severe and critical COVID-19 [3-5]. Currently, a clear-cut definition of hyperinflammation is lacking. Some authors describe the condition of hyperinflammation as a form of very severe inflammation with cytokine storm [6]. The criteria of hyperinflammation are not consistent and include clinical data and/or different combinations of the parameters of the activation of the pro-inflammatory response of the immune system (i.e. fever, rapid respiratory deterioration, cytokine, ferritin and/or CRP concentrations, changes in blood levels of several types of immune cells, etc., examples are presented in Table 1) [3, 4, 6-8, 9, 10-14]. In addition, the current definitions of hyperinflammatory syndrome do not provide an

Table 1 Examples of the criteria of hyperinflammation. These criteria are not consistent and include different combinations of symptoms and laboratory parameters of the activation of the pro-inflammatory response of the immune system

\begin{tabular}{|c|c|c|c|c|}
\hline \multirow[t]{2}{*}{ Author } & \multirow{2}{*}{$\begin{array}{l}\text { Year of } \\
\text { publication }\end{array}$} & \multicolumn{2}{|l|}{ Criteria of hyperinflammation } & \multirow{2}{*}{$\begin{array}{l}\text { Reference } \\
\text { number }\end{array}$} \\
\hline & & Clinical & Laboratory or pathogenesis & \\
\hline Webb BJ et al. & 2020 & $\begin{array}{l}\text { Fever (temperature of more } \\
\text { than } 38.0^{\circ} \mathrm{C} \text { ) }\end{array}$ & $\begin{array}{l}\text { Macrophage activation (ferritin concentration of } 700 \mu \mathrm{g} / \mathrm{l} \text { or more) } \\
\text { Haematological dysfunction (neutrophil to lymphocyte ratio of } 10 \text { or more or } \\
\text { both haemoglobin concentration of } 9.2 \mathrm{~g} / \mathrm{dl} \text { or less and platelet count of } 110 \\
\times 10^{9} \text { cells/L or less) } \\
\text { Haematological dysfunction (neutrophil to lymphocyte ratio of } 10 \text { or more or } \\
\text { both haemoglobin concentration of } 9.2 \mathrm{~g} / \mathrm{dl} \text { or less and platelet count of } 110 \\
\quad \times 10^{9} \text { cells/L or less) } \\
\text { Coagulopathy (D-dimer concentration of } 1.5 \mu \mathrm{g} / \mathrm{ml} \text { or more) } \\
\text { Hepatic injury (lactate dehydrogenase concentration of } 400 \mathrm{U} / \mathrm{L} \text { or more, or an } \\
\text { aspartate aminotransferase concentration of } 100 \mathrm{U} / \mathrm{L} \text { or more) } \\
\text { Cytokinaemia (defined as an IL- } 6 \text { concentration of } 15 \mathrm{pg} / \mathrm{ml} \text { or more, or a } \\
\text { triglyceride concentration of } 150 \mathrm{mg} / \mathrm{dl} \text { or more, or a CRP concentration of } \\
15 \mathrm{mg} / \mathrm{dl} \text { or more) }\end{array}$ & [7] \\
\hline $\begin{array}{l}\text { Fajgenbaum } \\
\text { DC and June } \\
\text { CH }\end{array}$ & 2020 & & Very severe inflammation with cytokine storm & [6] \\
\hline $\begin{array}{l}\text { Manson JJ } \\
\text { et al. }\end{array}$ & 2020 & & $\begin{array}{l}\text { C-reactive protein }(\mathrm{CRP}) \text { concentration greater than } 150 \mathrm{mg} / \mathrm{L} \\
\text { Doubling of CRP concentration within } 24 \mathrm{~h} \text { from a concentration of greater } \\
\text { than } 50 \mathrm{mg} / \mathrm{L} \\
\text { Ferritin concentration of greater than } 1500 \mu \mathrm{g} / \mathrm{L}\end{array}$ & [3] \\
\hline $\begin{array}{l}\text { Gustine JN and } \\
\text { Jones D }\end{array}$ & 2021 & & $\begin{array}{l}\text { Cytokine storm, dysregulated macrophage activation, impaired natural killer } \\
\text { cell response, lymphopenia, elevated absolute neutrophil count and } \\
\text { neutrophil/lymphocyte ratio and increased levels of neutrophil extracellular } \\
\text { traps (NETs) }\end{array}$ & [4] \\
\hline Anka AU et al. & 2021 & & $\begin{array}{l}\text { Excessive secretion of pro-inflammatory cytokines and the recruitment of } \\
\text { pro-inflammatory cells such as granulocytes and macrophages caused by } \\
\text { tissue injury result in a snowballing of cytokine secretion leading to a } \\
\text { systemic inflammatory response such as macrophage activation syndrome } \\
\text { (MAS), secondary haemophagocytic lymphohistiocytosis (sHLH-cyto- } \\
\text { kine storm) }\end{array}$ & {$[11]$} \\
\hline $\begin{array}{l}\text { Cardone } \mathrm{MC} \\
\text { et al. }\end{array}$ & 2020 & & $\begin{array}{l}\text { Increased plasma levels of pro- and anti-inflammatory cytokines (IL-1 } \beta, \text { IL-6, } \\
\text { IL-7, IL-8, IL-9, IL-10, IFN- } \gamma, \text { TNF), chemokines (MCP1, MIP1A, } \\
\text { MIP1B) and growth factors (G-CSF, GM-CSF) }\end{array}$ & {$[8]$} \\
\hline Mehta P et al. & 2020 & & $\begin{array}{l}\text { Trends in laboratory results such as increasing ferritin, decreasing platelet } \\
\text { counts or high erythrocyte sedimentation rate }\end{array}$ & 12 \\
\hline $\begin{array}{l}\text { Freeman TL } \\
\quad \text { et al. }(2020)\end{array}$ & 2020 & & $\begin{array}{l}\text { Vigorous stimulation of the innate immune response activating the Nod-like } \\
\text { receptor family, pyrin domain-containing } 3 \text { (NLRP3) inflammasome path- } \\
\text { way. This causes the release of the pro-inflammatory cytokines IL- } 6 \text { and } \\
\text { IL- } 1 \beta\end{array}$ & [13] \\
\hline $\begin{array}{l}\text { De Luca G } \\
\text { et al. }\end{array}$ & 2020 & & $\begin{array}{l}\text { Elevation of CRP to } \geq 100 \mathrm{mg} / \mathrm{L} \text { or ferritin to } \geq 900 \mu \mathrm{g} / \mathrm{L} \text { in the presence of any } \\
\text { increase in lactate dehydrogenase (LDH) }\end{array}$ & [14] \\
\hline Bozzi G et al. & 2021 & & Ferritin plasma levels of $\geq 1000 \mathrm{ng} / \mathrm{mL}$ and/or CRP of $>10 \mathrm{mg} / \mathrm{dl}$ & [9] \\
\hline $\begin{array}{l}\text { Landewé RBM } \\
\text { et al. }\end{array}$ & 2021 & $\begin{array}{l}\text { Rapid respiratory } \\
\text { deterioration on or during } \\
\text { admission }\end{array}$ & $\begin{array}{l}\text { Plus fulfilment of at least two out of three biomarker criteria: CRP of } \\
>100 \mathrm{mg} / \mathrm{L} \text {, serum ferritin of }>900 \mu \mathrm{g} / \mathrm{L} \text {, D-dimer of }>1500 \mu \mathrm{g} / \mathrm{L}\end{array}$ & {$[10]$} \\
\hline
\end{tabular}


explanation for the frequently observed co-infections or secondary infections in COVID-19 [15, 16].

The results of non-randomised cohort studies with controls and of retrospective observational studies suggest that IL-1 receptor blockade (anakinra) [9, 17], monoclonal antibodies against IL-6 receptors [18-21] and the combination of both drugs $[22,23]$ may improve survival rate in at least a subgroup of patients with COVID-19. However, in prospective randomised controlled trials with the exception of one trial with tocilizumab and sarilumab in critically patients [24], anti-inflammatory therapy with anakinra [25] or tocilizumab [26-32] did not improve the outcome in moderate, severe and critically ill COVID-19. On December 10, 2020, an editorial commented that it is disappointing that nearly 10 months into the COVID-19 pandemic, a breakthrough treatment has not been identified [33]. Researchers of the US National Institute of Allergy and Infectious Diseases stated that although Remdesivir is effective to reduce time to recovery in hospitalised COVID-19 patients [34] and dexamethasone reduces mortality in critically ill COVID-19 patients [35], there is no treatment for early or mild infection [36]. Moreover, dexamethasone raises concerns because it increased the 28-day mortality in patients who did not receive respiratory support [35] and it dampens the "alarm phase" of the inflammation process including the capacity of detecting pathogens in mammals by the immune system [37]. In addition, administration of methylprednisolone (1 $\mathrm{mg} / \mathrm{kg} /$ day intravenously) in COVID-19 reduced the blood levels of NK cells, CD4 ${ }^{+}$ and $\mathrm{CD} 8^{+} \mathrm{T}$-cells and increases the duration of throat viral RNA detectability indicating immune cell dysfunction [38]. Furthermore, targeted anti-viral medication has failed to treat COVID-19 effectively [39]. According to the World Health Organisation, after a record-breaking development, vaccine deployment is slow and has many challenges to overcome [40]. Vaccine hesitancy is relatively high [41] even among health care workers [42, 43]. It could take more than a year to vaccinate enough people required to make an impact on SARS-CoV-2 spreading, while therapeutic measures that can immediately attenuate the course of SARS-CoV-2-related lung damage are promptly needed on a global scale. To make the matters worse, many scientists expect that SARS-CoV-2 may become endemic and is here to stay [44].

In this report, we developed a novel definition of hyperinflammation based on purinergic signalling. Subsequently, we describe our discovery of an old drug capable of attenuating hyperinflammation and illustrate this with six critically ill patients suffering from COVID-19. Finally, we present the future development of a new and more accessible administration route for this drug as shown in Fig. 1.

\section{Purinergic signalling}

In 1929 adenylic acid (identical to adenosine) was identified [45], and in the same year, the adenosine triphosphate (ATP) molecule was discovered and isolated [46]. Ten years later (1939), researchers contributed to the understanding of intracellular ATP as an intracellular energy transport molecule [47-50]. In 1948 and in 1959, it was reported that extracellular ATP has a different function than ATP within the cytoplasm $[51,52]$. The authors showed that extracellular ATP molecules have an intercellular signalling function. The intercellular signalling by nucleotides (ATP, ADP, UTP and UDP) and nucleoside (adenosine) is referred to as purinergic signalling. The purinergic co-transmission in neurons was discovered by Geoffrey Burnstock in 1972 [53]. It took over 20 years for the importance of purinergic signalling to be accepted [54, 55]. Finally, researchers of the University of Ferrara first reported that the $\mathrm{P} 2 \mathrm{Z}$ receptor (the former name of the $\mathrm{P} 2 \mathrm{X} 7 \mathrm{R}$ ) plays an intriguing role in immunity, inflammation and cell death [56].

The intracellular levels of ATP are high at millimolar concentrations $(2-8 \mathrm{mM})$ [57], and the ATP concentrations in synaptic vesicles are even higher in the range of 5 to $100 \mathrm{mM}$ [58]. In contrast, under normal resting conditions, the extracellular levels of ATP are quite low at nanomolar concentrations $(<3 \mathrm{nM})[57,59]$. Under specific conditions, ATP release can rise by more than 1000 -fold $[53,57,60,61]$ and leads to a significant increase in the extracellular levels of ATP. The resulting significant increase in extracellular nucleotides and adenosine concentrations activates their purinergic receptors inducing certain cellular functions. Examples of such conditions are membrane depolarisation (i.e. sympathetic neuron endings) [53], mechanical stress (i.e. high mechanical power ventilation) [59-63], hypoxia [64], hyperosmosis, hypotonic and isotonic stress of endothelial cells [65-68], inflammation $[69,70]$, surfactant release by alveolar epithelial type II cells [59-61], mucine release by airway smooth muscle cells [71], insulin release by pancreatic islet beta-cells [72, 73], etc. There is an exception to this concept: Although a spontaneous ATP-induced inward $\mathrm{Ca}^{2+}$ current through the P2X7R could not be detected below extracellular ATP levels of $200 \mu \mathrm{mol} / \mathrm{ml}$ [74], low tonic basal activation of P2X7R at nanomolar extracellular ATP concentrations promotes serum independent cellular proliferation [75], promotes closure of the wound area in scratch wound assay [76], protects from apoptosis [77], initiates anaerobic glycolysis independent of the oxygen contents [78], etc. (Table 2, rows 80-85). However, low tonic basal activation of the P2X7Rs by extracellular ATP does not cause a pro-inflammatory response of the immune system. Therefore, this topic is beyond the scope of this paper and will not be discussed here.

Clearance of the ATP molecule in order to avoid accumulation in the extracellular space is performed by enzymes attached to the outside of the cell membranes (ecto-enzymes) 


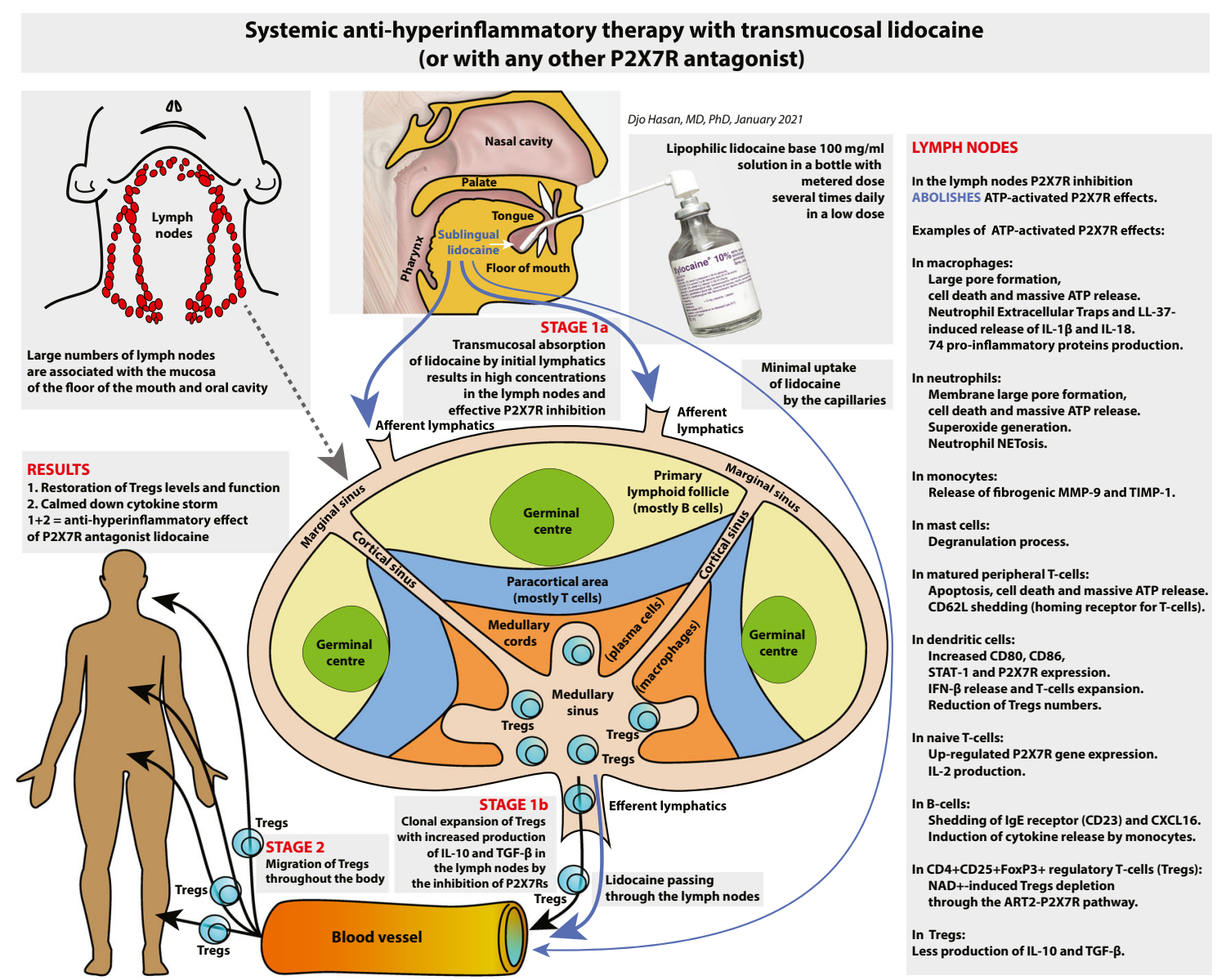

Fig. 1 A graphical summary of the future development of the administration of lipophilic lidocaine base in the sublingual region or elsewhere in the oral cavity. We postulate that selective inhibition of the P2X7Rs of the immune cells of the lymphatic system by lidocaine suppresses hyperinflammation in two stages. Stage 1: The selective inhibition of the P2X7Rs of the immune cells residing in the lymph

and by soluble enzymes excreted to the extracellular space (Fig. 2) [57, 272-275]. A proportion of the enzymaticbreakdown product of ATP adenosine enters the cells via the equilibrative nucleoside transporters (ENT1 and ENT2) and concentrative nucleoside transporters (CNT1 and CNT2) (Fig. 2) $[57,60,61]$. The release and subsequently clearance of the extracellular nucleotides and adenosine cause fluctuation in the extracellular levels of ATP, other nucleotides and adenosine. These fluctuations in extracellular concentrations are indispensable for the receptor resensitisation after desensitisation following receptor activation as discussed below.

\section{Purinergic signalling in inflammation and hyperinflammation}

The purinergic control of cellular processes including the proinflammatory and anti-inflammatory responses of the immune system is depending on the activation and the desensitisation nodes (stage 1a) induces clonal expansion of Tregs with improved function in these lymph nodes (stage 1b); Stage 2: Subsequently, these Tregs migrate throughout the body exerting anti-inflammatory activities reducing systemic and (distant) local hyperinflammation. See text under the heading "Future development" for explanation

phenomenon of the nucleotides and adenosine receptors of the immune cells [74, 276-282]. Except for the P2X7R, all other purinergic receptors, i.e. $\mathrm{P} 2 \mathrm{XRs}, \mathrm{P} 2 \mathrm{YRs}$ and $\mathrm{P} 1$ receptors (adenosine receptors-AdoRs), are subject to desensitisation [279-283]. In addition, a certain extent of desensitisation occurs after every activation, and this desensitisation requires time to return to the state of complete resensitisation [279, 280]. The higher and the longer the stimulus of the activation, the higher the extent of desensitisation and the longer the recovery time to the state of complete resensitisation [278]. One of the $\mathrm{P} 2$ receptors, the $\mathrm{P} 2 \mathrm{X} 7$ receptor, is not prone to desensitisation, and apart from the low tonic basal activation of this receptor at low nanomolar concentrations as mentioned above, the extracellular concentration of ATP required to activate this receptor is much higher. Activation of the P2X7R starts at $100 \mu \mathrm{M}$ with an $\mathrm{EC}_{50}$ of $>1 \mathrm{mM}$ [74, 279, 284].

Summary of the effects of extracellular nucleotides and nucleoside on the innate and adaptive immune system through different purinergic receptors is presented in Table 2, rows 1- 
Table 2 Summary of the effects of extracellular nucleotides and nucleoside on the innate and adaptive immune system through different purinergic receptors. AdoR adenosine receptor; $T N F-\alpha$ tumour necrosis factor alpha; $F c \gamma R$ receptors belonging to the immunoglobulin superfamily; IFN- $\gamma$ interferon gamma; IFN- $\beta$ interferon beta; MAC-1 macrophage- 1 antigen comprised $\mathrm{CD} 11 \mathrm{~b}$ (integrin $\alpha \mathrm{M}$ ) and $\mathrm{CD} 18$ (integrin $\beta 2$ ); $C p G-A$ oligodeoxynucleotides; PARP Poly ADP ribose polymerase; FMLP N-Formylmethionyl-leucyl-phenylalanine, a chemotactic factor; $C O X-2$ cytochrome C oxidase polypeptide II; $P G E 2$ prostaglandin E2; MIP-1 $\alpha$ macrophage inflammatory protein 1 alpha (MIP-1 $\alpha=C C L 3$ chemokine ligand 3 ), MIP-1 $\beta$ (CCL4), MIP- $2 \alpha$ (CXCL2 chemokine CXC motif ligand 2) and MIP$3 \alpha$ (CCL20); RANTES (Regulated on Activation, Normal T cell Expressed and Secreted, CCL5); LTB4 Leukotriene B4; LTA4 Leukotriene A4; VCAM-1 vascular cell adhesion molecule 1 (CD106);ICAM-1 intercellular adhesion molecule 1 (CD54);HMGB-1 high-mobility group box 1 (belongs to danger-associated molecular patterns); $M C P-1$ monocyte chemoattractant protein 1 (CCL2);FoxP3 Forkhead box P3; CTL cytotoxic T lymphocyte; Th T helper cell; CTLA-4 cytotoxic T-lymphocyte-associated protein 4 (CD152); CD39 nucleoside triphosphate diphosphohydrolase 1 (NTPD1);CD735'nucleotidase (5'-NT); VEGF vascular endothelial growth factor; $I D O$ Indoleamine-pyrrole 2,3-dioxygenase; $\alpha$-SMA alpha smooth muscle actin; $C T G F$ connective tissue growth factor (CCN2); $b F G F$ basic fibroblast growth factor; TCRT-cell receptor; NFAT nuclear factor of activated $\mathrm{T}$ cells; NLRP3Nod-like receptor family pyrin domain containing 3 gene; ART2-P2X7 pathway extracellular NAD+-induced ATP-independent p2X7R activation involving ADP-ribosyltransferase 2; $M M P-9$ matrix metalloproteinase-9;TIMP-1 tissue inhibitor of metalloproteinase $1 ; L C$ MS/MS liquid chromatography and tandem mass spectrometry; STAT-1 signal transducer and activator of transcription 1. Updated table, source: Hasan D, et al. (2017) [60] with permission

Effects of extracellular nucleotides and nucleoside on the innate and adaptive immune system through different purinergic receptors

\begin{tabular}{|c|c|c|c|c|c|}
\hline $\begin{array}{l}\text { Row } \\
\text { number }\end{array}$ & Receptor & Ligand [52] & $\begin{array}{l}\text { Immune cell expression or experimental } \\
\text { model }\end{array}$ & Results of receptor signalling & $\begin{array}{l}\text { Reference } \\
\text { number }\end{array}$ \\
\hline 1 & AdoRA1 & Adenosine & Neutrophils & Promotes chemotaxis & {$[79,80]$} \\
\hline 2 & & & Neutrophils & Increases adherence to endothelial cells & {$[81]$} \\
\hline 3 & & & Neutrophils & Inhibits TNF- $\alpha$ release & {$[82]$} \\
\hline 4 & & & Neutrophils & $\begin{array}{l}\text { At low concentrations adenosine enhances } \\
\text { Fc } \gamma \text { R phagocytosis and actin dynamics }\end{array}$ & {$[83-85]$} \\
\hline 5 & & & Neutrophils & Restores LPS-inhibited chemotaxis & {$[86]$} \\
\hline 6 & & & Resting DCs (rDCs) & $\begin{array}{l}\text { Inhibits vesicular MHC class I } \\
\text { cross-presentation }\end{array}$ & {$[87]$} \\
\hline 7 & & & Plasmacytoid DCs (pDCs) & $\begin{array}{l}\text { Potent chemoattractants, reduces IL- } 6 \text {, } \\
\text { IL- } 12 \text { and IFN- } \gamma \text { release }\end{array}$ & {$[88]$} \\
\hline 8 & $\begin{array}{l}\text { AdoRA1 } \\
\text { and } \\
\text { AdoR- } \\
\text { A2A }\end{array}$ & & CD39 ${ }^{\text {high }}$ B-cells (Bregs) & $\begin{array}{l}\text { Promotes expansion and function of } \\
\text { CD39 } 9^{\text {high }} \text { B-cells }\end{array}$ & {$[89,90]$} \\
\hline 9 & AdorA2A & Adenosine & Monocytes & Inhibits IL-12 and TNF- $\alpha$ release & {$[91,92]$} \\
\hline 10 & & & Neutrophils & Promotes chemotaxis & {$[80]$} \\
\hline 11 & & & Neutrophils & Inhibits oxygen radical generation & {$[79]$} \\
\hline 12 & & & Neutrophils & $\begin{array}{l}\text { Inhibits upregulation of beta } 2 \text { integrins or } \\
\text { MAC-1 (CD11/CD18) and shedding of } \\
\text { L-selectin by FMLP }\end{array}$ & {$[93,94]$} \\
\hline 13 & & & Neutrophils & Promotes Cox-2 and PGE2 release & {$[95]$} \\
\hline 14 & & & Neutrophils & Decreases adherence to endothelial cells & {$[81]$} \\
\hline 15 & & & Neutrophils & $\begin{array}{l}\text { Decreases adherence to fibrinogen coated } \\
\text { surfaces }\end{array}$ & [96] \\
\hline 16 & & & Neutrophils & $\begin{array}{l}\text { Inhibits TNF- } \alpha \text { release and chemokines } \\
\text { MIP- } 1 \alpha \text { (CCL3), MIP- } 1 \beta \text { (CCL4), } \\
\text { MIP- } 2 \alpha \text { (CXCL2) and MIP-3 } \alpha \text { (CCL20) }\end{array}$ & {$[82,97]$} \\
\hline 17 & & & Neutrophils & $\begin{array}{l}\text { At high concentrations adenosine inhibits } \\
\text { Fc } \gamma \mathrm{R} \text { functions and actin dynamics }\end{array}$ & {$[83-85]$} \\
\hline 18 & & & Neutrophils & $\begin{array}{l}\text { Inhibits leukotriene (LTB4, LTA4) } \\
\text { synthesis }\end{array}$ & [98-102] \\
\hline 19 & & & Neutrophils & $\begin{array}{l}\text { Inhibits degranulation and superoxide } \\
\text { release or oxidative burst }\end{array}$ & {$[96,103-106]$} \\
\hline 20 & & & Neutrophils & Delays neutrophil apoptosis & {$[107]$} \\
\hline 21 & & & Neutrophils & $\begin{array}{l}\text { Inhibits autophagy suppressed apoptosis of } \\
\text { neutrophils by blocking caspase-8, } \\
\text { caspase- } 3 \text { and PARP signalling }\end{array}$ & {$[108]$} \\
\hline 22 & & & Mast cells & Increases IL- $1 \beta$, IL- 3 and IL- 8 release & [109] \\
\hline 23 & & & Macrophages & Inhibits LPS-induced TNF- $\alpha$ release & {$[110]$} \\
\hline 24 & & & Endothelial cells & & [111] \\
\hline
\end{tabular}


Table 2 (continued)

Effects of extracellular nucleotides and nucleoside on the innate and adaptive immune system through different purinergic receptors

\begin{tabular}{|c|c|c|c|c|c|}
\hline $\begin{array}{l}\text { Row } \\
\text { number }\end{array}$ & Receptor & Ligand [52] & $\begin{array}{l}\text { Immune cell expression or experimental } \\
\text { model }\end{array}$ & Results of receptor signalling & $\begin{array}{l}\text { Reference } \\
\text { number }\end{array}$ \\
\hline
\end{tabular}

Naïve T-cells

Th1, Th2 and Th17cells

CD8 ${ }^{+}$CTLs, Th1, Th2

$\mathrm{CD}^{+}{ }^{+} \mathrm{T}$-cells

$\mathrm{CD} 4^{+} \mathrm{CD} 25^{+} \mathrm{FoxP}^{+}{ }^{+}$Tregs

$\mathrm{CD} 4^{+} \mathrm{CD} 25^{+} \mathrm{FoxP}^{+}{ }^{+}$Tregs

AdoRA2A-knockout mice

Human leukaemia monocytic cell line THP-1 cells

Human CD4+ CD25+ CD127low/- Tregs and CD8+ T-cells

Reduces thrombin-induced permeability. Inhibits thrombin-mediated expression of VCAM-1, ICAM-1 an E-selectin. Inhibits thrombin induced increase of IL-6, HMGB-1; chemokines, MCP-1 (CCL-2), CXCL-1 and CXCL-3

Promotes the differentiation towards $\mathrm{CD}^{+}{ }^{+} \mathrm{FoxP}_{3}{ }^{+} \mathrm{Lag} 3^{+}$Tregs, inhibits Th1 and Th17 differentiation, inhibits IL-6 secretion and increases TGF- $\beta$ secretion

Reduces release of IL-2, IL-4, TNF- $\alpha$ and IFN- $\gamma$

Reduces release of IL-2, TNF- $\alpha$, IFN- $\gamma$. Inhibits $\mathrm{CD} 8^{+} \mathrm{CTL}$ and $\mathrm{Th} 1$ expansion to alloantigens

Inhibits TCR-mediated IFN- $\gamma$ release

Increases number of Tregs and increases the expression of CTLA-4 receptor

Upregulates ecto-enzymes CD39 and CD73 expression accelerating adenosine generation from extracellular ATP

Bleomycin-induced fibrosis is more severe and elevated TGF- $\beta$ is higher than in wild-type mice

TNF- $\alpha$ upregulates the expression of AdoRA2A followed by the increase of the expression of CD163 and TGF- $\beta 1$

Tregs from gastric cancer patients hydrolyse ATP into adenosine. Adenosine synthesised by Tregs promotes apoptosis and suppresses proliferation of CD8+ T-cells. Tregs reduces CD8+ T-cell activity by promoting cAMP synthesis. Tregs Inhibit the immune function of CD8+ T-cells through A2aR pathway

Differentiation of monocytes towards M2 macrophages with VEGF and IL-10 release

AdorA2-

Macrophages

B

Macrophages

AdoRA2B Adenosine Neutrophils

Neutrophils

Neutrophils

Mast cells

Macrophages

DCs

Inhibits LPS-induced IL-6, MIP-2 and TNF- $\alpha$ release

Inhibits neutrophil recruitment and transmigration, release of TNF- $\alpha$, IL-6, MIF- $1 \propto$ and IL- 8

Inhibits superoxide generation

Inhibits TNF- $\alpha$ release

Stimulates degranulation (mice), IL-13, IL-4 (Th2 cytokines)

Stimulates IL-10 release

Differentiation and maturation towards regulatory DCs: High level expression of angiogenic (VEGF), wound healing (IL-6), chemokine (IL-8), immune suppressing (IL-10) and tolerogenic (IDO) factors

Promotes Th17 differentiation via stimulation of IL-6 release 
Table 2 (continued)

Effects of extracellular nucleotides and nucleoside on the innate and adaptive immune system through different purinergic receptors

\begin{tabular}{|c|c|c|c|c|c|}
\hline $\begin{array}{l}\text { Row } \\
\text { number }\end{array}$ & Receptor & Ligand [52] & $\begin{array}{l}\text { Immune cell expression or experimental } \\
\text { model }\end{array}$ & Results of receptor signalling & $\begin{array}{l}\text { Reference } \\
\text { number }\end{array}$ \\
\hline
\end{tabular}

43

44

45

57
Bone marrow cells

Myeloid cells in systemic bleomycin-induced pulmonary fibrosis

Mast cells

B-cells

Endothelial cells

Endothelial cells

Bronchial epithelial cells

Human leukaemia monocytic cell line THP-1 cells

Renal fibroblasts

AdoR2B knock-out mice

AdorR2B knock-out mice exposed to systemic bleomycin

Specific pathogen-free male Sprague-Dawley rats

RAW 264.7 murine macrophage cells with and without transfection with AdoRA2B siRNA cultured with B. abortus 544 biovar 1 strain (ATCC 23448)
Mast cells

and

AdoR-

A3

AdoRA3 Adenosine
Promotes differentiation towards CD $11 \mathrm{c}^{+} \mathrm{Gr}-1^{+}$DCs that promotes Th17 response

Myeloid cells AdorA2B knock out mice show a reduction in CD206 and arginase-1 (markers for M2 macrophages). 10-fold reduction in IL-6 and 5 -fold reduction in hyaluronan (both linked to pulmonary fibrosis)

Upregulates the IL-4 and IL-13 release

Induces Ig-E release through IL-4 and IL-13 release by the adenosine-activated mast cells

Reduces endothelial permeability, ICAM-1, P-selectin and E-selectin (adhesion molecules)

Stimulates basic fibroblast growth factor (bFGF) and insulin-like factor-1 release Increases IL-19 release

Increases TNF- $\alpha$ release through mast cell-released IL-19

Increases the expression of $\alpha$-SMA, IL-6, [140] TGF- $\beta$, CTGF and fibronectin (pro-fibrotic mediators)

Negligible effect on bleomycin-induced acute lung injury. Enhanced loss of barrier function

Substantial reduction of fibrosis and IL-6 production

Inhibition of AdoRA2B: Attenuates necrotizing enterocolitis in newborn rats and protects against body weight loss, decreases myeloperoxidase activity, decreases TNF- $\alpha$, IFN- $\gamma$ and IL- 6 intestinal levels and increases IL-10 intestinal levels

Blocking of Adora $2 b$ using siRNA induces productions of IL-6, MCP- 1 and TNF- $\alpha$ in cells without infection. Adora2b siRNA macrophages have reduced uptake of $B$. abortus. Inhibition of AdoRA2B results in higher total weight of the spleens and less Brucella colonisation in this organ, decreases IL-10, elevates the levels of IFN- $\gamma$ and IL-12 at three days p.i. and elevates the levels of IL-6, TNF- $\alpha$ and IL-12 at 14 days p.i.

Stimulates IL-8(chemokine) and VEGF (angiogenic) release

Simultaneous adenosine AdoRA2B and AdoR3 signalling is required to promote chemotactic migration of macrophages towards the apoptotic cells

Synergistic AdorA3 and P2Y2R neutrophil [146-152] chemotaxis through autocrine ATP release by pannexin-1, extracellular AdoRA2A knockout and AdoRA3 knockout FVB or C57BL/6 male mice

Neutrophils 
Table 2 (continued)

Effects of extracellular nucleotides and nucleoside on the innate and adaptive immune system through different purinergic receptors

\begin{tabular}{|c|c|c|c|c|c|}
\hline $\begin{array}{l}\text { Row } \\
\text { number }\end{array}$ & Receptor & Ligand [52] & $\begin{array}{l}\text { Immune cell expression or experimental } \\
\text { model }\end{array}$ & Results of receptor signalling & $\begin{array}{l}\text { Reference } \\
\text { number }\end{array}$ \\
\hline
\end{tabular}

Microglial cells and colonic epithelial cells

Anti-CD3-activated $\mathrm{CD} 8^{+} \mathrm{CTLs}$

Microglia BV-2 cell line

AdoRA3 knock-out mice exposed to intratracheal bleomycin

Human colonic mucosa biopsies

Neutrophils and platelets

Bovine polymorphonuclear leukocytes (PMNs)

Naïve T-cells

Mast cells

$\gamma \delta \mathrm{T}$-cells

Microglial cells

$\mathrm{CD} 4^{+} \mathrm{T}$-cells from Human peripheral blood mononuclear cells (PMBCs) conversion of ATP to adenosine by the ecto-enzymes (CD39 and CD73), strategic translocation of the FPR, AdorA3, P2Y2, pannexin-1 receptors and CD39, $\mathrm{Cd} 73$ to the leading edge of the neutrophils. This results in the amplification of the chemoattractant gradient sensing and the self-generated gradients

Suppresses LPS-induced TNF- $\alpha$ production

Reduces the expression of mRNAs coding for granzyme B, perforin, Fas ligand and TNF-related apoptosis-inducing ligand (TRAIL). Diminishes

Nalpha-CBZ-L-lysine thiobenzylester esterase activity (enzyme with cytotoxic activity). Reduces IL-2 sand IFN- $\gamma$ release.

Reduces elevated hydrostatic pressure-induced inducible nitric oxide synthase (iNOS) expression, microglia migration and phagocytosis in $\mathrm{BV}-2$ cells

Increase in eosinophil numbers and selective upregulation of eosinophil-related chemokines and cytokines. But decreased eosinophil peroxidase activity in the BALF

Significantly decreases TNF- $\alpha$ and IL- $1 \beta$ production and attenuates the NF-kBp65 activation

Promotes thrombosis and fibrinogenesis: Keeps circulating neutrophils in quiescent state, recruit neutrophil to the injury site, activate adhered neutrophils and platelets

Oleic acid (OA) and linoleic acid (LA) induce Neutrophil Extracellular Traps (NETs) formation and ATP release via PANX1 and activation of P2X1

TCR stimulation results in the translocation of pannexin-1 hemichannels, P2X1Rs and P2X4Rs to the immune synapse. While the P2X7Rs remain uniformly distributed. This process is required to induce calcium entry, NFAT and release of IL-2

Increases the expression of IL-4, IL-6, IFN- $\gamma$, TNF- $\alpha$, RANTES and M IP-2. Increases the release of IL- 6 and IL-13

Article retracted due to figure irregularities [162]

Activates and upregulates TNF- $\alpha$ and IFN- $\gamma$ release

Promotes survival after LPS-activation [164]

Chemokine stromal-derived factor- $1 \alpha$ $(\mathrm{SDF}-1 \alpha)$ triggered mitochondrial ATP
[163] 
Table 2 (continued)

Effects of extracellular nucleotides and nucleoside on the innate and adaptive immune system through different purinergic receptors

\begin{tabular}{|c|c|c|c|c|c|}
\hline $\begin{array}{l}\text { Row } \\
\text { number }\end{array}$ & Receptor & Ligand [52] & $\begin{array}{l}\text { Immune cell expression or experimental } \\
\text { model }\end{array}$ & Results of receptor signalling & $\begin{array}{l}\text { Reference } \\
\text { number }\end{array}$ \\
\hline
\end{tabular}

$\begin{array}{lll}74 & \begin{array}{c}\text { P2X4R } \\ \text { and } / \text { or } \\ \text { P2X7R }\end{array} & \text { ATP } \\ & & \\ & & \text { P2X } 5 \mathrm{R}\end{array}$

Chinese hamster ovary $(\mathrm{CHO})$ cells transfected with human Kv1.3 cDNA and rat $\mathrm{P} 2 \mathrm{X} 4$ construct mononuclear cells (PMBCs), Jurkat T cells (clone E6-1) and U-937 cells
$\mathrm{CD}^{+} \mathrm{T}$-cells from Human peripheral blood

production, rapid bursts of ATP release and increased migration of primary human $\mathrm{CD} 4+\mathrm{T}$ cells. This process depended on pannexin-1 ATP release channels and autocrine stimulation of P2X4Rs. SDF- $1 \alpha$ stimulation caused localised accumulation of mitochondria with P2X4Rs near the front of cells, resulting in a feed-forward signalling mechanism that promotes cellular $\mathrm{Ca} 2+$ influx and sustains mitochondrial ATP synthesis at levels needed for pseudopod protrusion, $\mathrm{T}$ cell polarisation and cell migration

The voltage-gated potassium channel $\mathrm{Kv} 1.3$ is required for microglia activation. Inhibition of Kv1.3 channels completely nullified the ability of Kv1.3 to normalise membrane potential changes, resulting in excessive depolarisation and reduced calcium transients through $\mathrm{P} 2 \mathrm{X} 4$ receptors

P2Y11Rs retract from the immune synapse (IS) towards the back of cells where their stimulation by extracellular ATP induces cAMP/PKA signalling that redirects mitochondrial trafficking to the IS. P2Y11Rs thus reinforce IS signalling by promoting the aggregation of mitochondria with panx1 ATP release channels and P2X4 receptors at the IS. This dual purinergic signalling mechanism involving P2X4Rs and P2Y11Rs focuses mitochondrial metabolism to the IS where localised ATP production sustains synaptic activity in order to allow successful completion of $\mathrm{T}$ cell activation responses

CD4+ T-cells from Human peripheral blood Autocrine P2X4R and simultaneous mononuclear cells (PMBCs)

P2Y11R activation regulate mitochondrial metabolism, T-cell polarisation, pseudopod formation and redistribution of P2Y11Rs to the back of polarised T-cells resulting in T-cell trafficking. Exogenous activation of P2Y11R blocks T-cell trafficking

Neutrophils, monocytes, macrophages, DCs, Mediates NLRP3 inflammasome-dependent IL-1 $\beta$ and IL-18 secretion (signal 2, non-classical pathway), increases IL-6 production

P2X5R-deficient BMMs exhibit defective cytosolic killing of L. monocytogenes $\mathrm{P} 2 \mathrm{X} 5 \mathrm{R}$ is required for $\mathrm{L}$. monocytogenes-induced inflammasome activation and IL- $1 \beta$ production and that defective L. monocytogenes killing in P2X5R-deficient BMMs is substantially rescued by exogenous IL-1 $\beta$ or IL-18. The P2X5-dependent anti-L. knockout, P2X7R knockout and 2X5R/P2X7R knockout and their 
Table 2 (continued)

Effects of extracellular nucleotides and nucleoside on the innate and adaptive immune system through different purinergic receptors

\begin{tabular}{|c|c|c|c|c|c|}
\hline $\begin{array}{l}\text { Row } \\
\text { number }\end{array}$ & Receptor & Ligand [52] & $\begin{array}{l}\text { Immune cell expression or experimental } \\
\text { model }\end{array}$ & Results of receptor signalling & $\begin{array}{l}\text { Reference } \\
\text { number }\end{array}$ \\
\hline
\end{tabular}

$\begin{array}{ll}76 \quad \text { P2X7R } & \begin{array}{l}\text { Unactivated state in } \\ \text { the absence of } \\ \text { ATP } \\ 77 \\ \text { ATP release } \\ \text { channel }\end{array}\end{array}$

Macrophages and P2X7R-transfected HEK-293 cells

Alveolar epithelial type I cells (AT I cells), mice osteoclast cells, murine neuroblastoma cells, astrocytic cell line, mice astrocytes, B16 melanoma cells ATP release
Mouse 3T3fibroblasts

Bone marrow-derived dendritic cells from WT mice and Panx 1-/- C57BL/6 mice

HET293 and HELA cells

In-vitro scratch wound assay with HaCat cells (human skin keratinocytes)

PC3 cells LNCaP, Kelly, RPMI-8226, DU145 and SK-MEL-5 cells Osteoclast-like cells

HEK293 cells
HEK293 and NIH3T3 cells monocytogenes immunity is independent of the ATP-P2X7 inflammasome activation pathway

$\mathrm{P} 2 \mathrm{X} 7$ is a scavenger receptor for apoptotic $[178,179]$ cells in the absence of $i$ ts ligand ATP

Release ATP after mechanical deformation [180-185] (AT I cells), spontaneously (osteoblast cells), after activation (neuroblastoma cells, astrocytic cell line), after $\gamma$ irradiation (melanoma cells)

P2X7R-mediated ATP secretion is accompanied by depletion of cytosolic ATP

Upon stimulation of the $\mathrm{P} 2 \mathrm{X} 7$ receptor by ATP, Panx 1 contributed to fast DC motility by increasing the permeability of the plasma membrane, which resulted in supplementary ATP release

Elevates mitochondrial calcium and potential, cellular ATP levels and promotes serum-independent growth. This process requires a full pore-forming function

Medium hyaluronan fragment (MMW-HA, between 100 and $300 \mathrm{kD}$ ) increases tight junction ZO-1 protein expression and induces a low activation of $\mathrm{P} 2 \mathrm{X} 7$ receptor resulting in improved closure of the wound area. This is accompanied by pore formation as shown by Yo-Pro-1 cellular uptake. The P2X7R antagonist brilliant blue $\mathrm{G}$ (BBG) completely inhibits this process

Increases the $\mathrm{Ca} 2+$ content of the endoplasmic reticulum, activates NFATc1 and protects from apoptosis

Drives the expression of nfP2X7, a key mediator of cell survival

Promotes the increase in the extracellular adenosine concentrations

The initiation of anaerobic glycolysis independent of the oxygen content: Upregulates glucose transporter Glut1 (thus enhances intracellular glycogen stores); Upregulates glycolytic enzymes (PFK, G3PDH, PKM2), phosphorylated $\mathrm{Akt} / \mathrm{PKB}$ and hypoxia-inducible factor 1a (HIF-1a) expression

Impedes the Krebs cycle independent of the oxygen concentrations: Promotes pyruvate dehydrogenase kinase 1 (PDHK1) and inhibits of pyruvate dehydrogenase (PDH, conversion of pyruvate to acetyl-coA)

P2X7 activation inhibits the suppressive potential and stability of Tregs. In contrast, P2X7R inhibition promotes the conversion of the cell-autonomous 
Table 2 (continued)

Effects of extracellular nucleotides and nucleoside on the innate and adaptive immune system through different purinergic receptors

\begin{tabular}{|c|c|c|c|c|c|}
\hline $\begin{array}{l}\text { Row } \\
\text { number }\end{array}$ & Receptor & Ligand [52] & $\begin{array}{l}\text { Immune cell expression or experimental } \\
\text { model }\end{array}$ & Results of receptor signalling & $\begin{array}{l}\text { Reference } \\
\text { number }\end{array}$ \\
\hline
\end{tabular}
(TCRs) CD90/CD45RB ${ }^{\text {low }}$ FoxP3 $^{+}$Tregs in colon lamina propria, prevents Tregs death in mesenteric lymph nodes and these Tregs produce more IL-10. Colitis is prevented or reduced and $\mathrm{P} 2 \mathrm{X} 7$ knock-out mice. Treg cells lacking the P2X7 receptor have higher levels of integrin CD103

C57BL/6 mice and foetal thymus organ culture

C57BL/6J mice implanted with melanoma B16F10 cells
Dendritic cells cultured from mice bone marrow precursor cells

RAW 264.7 murine macrophages

Monocytes

M1 macrophages

M2 macrophages

Macrophages

Macrophages and P2X7R-transfected HEK-293 cells

Mast cells
P2X7R activation reduces the frequency of Tregs and P2X7R inhibition increases the expansion of Tregs

Selectively increases immature $\gamma \delta+C D 25+$ cells which are much more competent to release ATP than pre-TCR expressing cells following TCR stimulation and $\mathrm{Ca} 2+$ influx. Genetic ablation as well as pharmacological antagonism of $\mathrm{P} 2 \mathrm{X} 7$ results in impaired ERK

phosphorylation, reduction of early growth response (Egr) transcripts induction, diversion of

$\gamma \delta \mathrm{TCR}$-expressing thymocytes towards the $\alpha \beta$ lineage fate and increased representation of the Id3-independent NK1.1-expressing $\gamma \delta$ T-cell subset in the periphery

$\mathrm{P} 2 \mathrm{X} 7$ activation in tumour infiltrating CD8+ lymphocytes (TILs) promotes cell cycle arrest and p38 MAPK mediated cellular senescence in the tumour microenvironment

P2X7 receptor-dependent blebbing and the activation of Rho-effector kinases, caspases and IL- $1 \mu \beta$ release

Autocrine-mediated (pannexin-1 channels) fast migration of dendritic cells through the reorganisation of the actin cytoskeleton

mediates actin reorganisation and membrane blebbing via $\mathrm{p} 38$ MAP kinase and Rho

Induces MMP-9 and TIMP-1 release, fibrosis markers

Induces release of 74 pro-inflammatory proteins detected by antibody protein array and 33 inflammatory proteins detected by LC-MS/MS

Induces release of 21 anti-inflammatory proteins detected by LC-MS/MS

Enhances intracellular bacterial killing

Mediates rapid uptake of beads and bacteria in the absence of serum after ATP activation

Induces degranulation 
Table 2 (continued)

Effects of extracellular nucleotides and nucleoside on the innate and adaptive immune system through different purinergic receptors

\begin{tabular}{|c|c|c|c|c|c|}
\hline $\begin{array}{l}\text { Row } \\
\text { number }\end{array}$ & Receptor & Ligand [52] & $\begin{array}{l}\text { Immune cell expression or experimental } \\
\text { model }\end{array}$ & Results of receptor signalling & $\begin{array}{l}\text { Reference } \\
\text { number }\end{array}$ \\
\hline
\end{tabular}

100

101

102

103

104

111

\section{Naïve NKTs}

Activated NKTs

B cells

$\mathrm{CD} 11 \mathrm{c}^{+} \mathrm{CD} 103^{+} \mathrm{DCs}$

Naïve T-cells

T follicular B helper cells (Tfh cells)

$\mathrm{CD}^{+} \mathrm{CD} 25^{+} \mathrm{FoxP}^{+}$regulatory T-cells (Tregs)

DCs

AT I cells

Human endometrial mesenchymal stem cells, murine luteal cells

Brain-derived type-2 astrocyte cell, mesangial cells

Sprague-Dawley rats with and without spinal cord injury

Abdominal cells of male Kunming mice of clean grade

Human embryonic kidney cells (HEK293T)
Facilitates NAD ${ }^{+}$-induced inhibitory signal [201] through the ART2-P2X7 pathway resulting in non-functional NKTs

Facilitates $\mathrm{NAD}^{+}$-induced stimulatory signal through the ART2-P2X7 pathway resulting in functional NKTs with increased IFN- $\gamma$ and IL-4 release

Induces shedding of IgE receptor (CD23) and CXCL16. Soluble CD23 sustains growth of B-cell precursors, promotes B and $\mathrm{T}$ cell differentiation and drives cytokine release from monocytes. CXCL16 is a chemoattractant for lymphocytes

Mediates infection-induced rapid recruitment of $\mathrm{CD} 11 \mathrm{c}^{+} \mathrm{CD} 103^{+} \mathrm{DC}$ subsets into the epithelial layer of the gut

TCR stimulation triggers rapid release of ATP and upregulates $\mathrm{P} 2 \mathrm{X} 7$ gene expression. Autocrine ATP stimulation through the P2X7R is required to for the TCR-mediated calcium influx, NFAT activation and IL-2 production

Reduces and thus controls the number of Tfh cells in Peyer's patches in the gut with high-affinity IgA responses to promote host-microbiota mutualism

Facilitates $\mathrm{NAD}^{+}$-induced Tregs depletion through the ART2-P2X7 pathway

Increases CD80, CD 86, STAT-1 and P2X7R expression, IFN- $\beta$ release and T-cells expansion. Reduces Tregs numbers

Induces VCAM-1 shedding and neutrophil transmigration in acute lung injury

Causes cell cycle arrest in G0/G1 phase and suppresses cell replication

Stimulates TGF- $\beta$ mRNA expression microglia was upregulated by BzATP and down-regulated by P2X7R antagonist A-438079. Upregulation of P2X7R on microglia coincides with increase of neuroinflammation after spinal cord injury. P2X7R of microglia participates in spinal cord-mediated neuroinflammation via regulating NLRP3 inflammasome-dependent inflammation Transfection of the long non-coding siRNA uc. $48+$ decreases the upregulated mRNA and protein levels of the P2X7 receptor in diabetes mellitus type 2 mice model

Promotes paxillin and NLRP3 migration from the cytosol to the plasma membrane and facilitates P2X7R-paxillin interaction and 
Table 2 (continued)

Effects of extracellular nucleotides and nucleoside on the innate and adaptive immune system through different purinergic receptors

\begin{tabular}{|c|c|c|c|c|c|}
\hline $\begin{array}{l}\text { Row } \\
\text { number }\end{array}$ & Receptor & Ligand [52] & $\begin{array}{l}\text { Immune cell expression or experimental } \\
\text { model }\end{array}$ & Results of receptor signalling & $\begin{array}{l}\text { Reference } \\
\text { number }\end{array}$ \\
\hline
\end{tabular}

115

P2Y1R knockout, P2Y12R knockout, P2Y13R knockout, P2X7R knockout, NLRP3 knockout and wild type C57BL/6 mice

C57BL/6 mice: Wild-type, P2X7 knockout, NLRP3 knockout and caspase-1/11 knockout

$\mathrm{C} 57 \mathrm{BL} / 6 \mathrm{~J}$ mice and their peritoneal macrophages, immortalised human liver stellate cell line LX-2 and immortalised human leukaemia monocytic cell line THP-1 cells

Macrophages derived from human leukaemia monocytic cell line THP-1 cells cultured with T. pallidum with and without P2X7R gene siRNA-transfection

Human and mice macrophages

\section{ATP $>1 \mathrm{mM}$, prolonged vigorous activation}

Macrophage, HeLa cells, 1321-N1 astrocytes and HEK293 cells

Human neutrophils and HL-60 cells

Matured peripheral T-cells
PaxillinNLRP3 association, resulting in the formation of the P2X7R-Paxillin-NLRP3 complex. Paxillin is essential for ATP-induced NLRP3 inflammasome activation in mouse bone marrow-derived macrophages and bone marrow-derived dendritic cells (PMDCs) as well as in human PBMCs and THP-1-differentiated macrophages

Aggravates inflammatory bowel disease through ERK5-mediated tyrosine phosphorylation of the adaptor protein ASC essential for NLRP3 inflammasome activation and the secretion of IL- $1 \beta$

Induces the release of extracellular vesicles containing CD14. Extracellular CD14 induced during sepsis controls bacterial dissemination and cytokine secretion

Blockade of P2X7R reverses

TAA-induced liver fibrosis thioacetamide and attenuates thioacetamide-induced inflammatory response by inhibiting NLRP3 and NF-KB activation in mice liver. P2X7R overexpression significantly enhances TGF- $\beta$-increased $\alpha$-SMA and collagen I protein and mRNA level in LX-2 cells. Macrophages increase fibrogenesis in LX-2 HSCs through the release of IL- $1 \beta$ by $\mathrm{P} 2 \times 7 \mathrm{R}$ stimulation

T. pallidum increases both the mRNA and protein levels of $\mathrm{P} 2 \mathrm{X} 7 \mathrm{R}$, increases levels of NLRP3 mRNA expression and IL-1 $\beta$. SiRNA transfection of the macrophages reduces the percentage of spirochete-positive macrophages and spirochete internalisation

Enhances the Neutrophil Extracellular Traps (NETs) and LL-37 formation (an antibacterial protein externalised on NETs) activated caspase- 1 , the central enzyme of the inflammasome, in both human and murine macrophages, resulting in release of active IL- $1 \beta$ and IL-18. LL-37 activation of the NLRP3 Inflammasome utilises P2X7R-mediated potassium efflux. IL-18 can stimulate NETosis (NET activation and release) in human neutrophils

Induces pannexin-1 mediates large pore formation and IL- $1 \beta$ release

Mediates membrane large pore formation and superoxide generation

High dose ATP promotes apoptosis, cell death and CD62L shedding (homing 
Table 2 (continued)

Effects of extracellular nucleotides and nucleoside on the innate and adaptive immune system through different purinergic receptors

\begin{tabular}{|c|c|c|c|c|c|}
\hline $\begin{array}{l}\text { Row } \\
\text { number }\end{array}$ & Receptor & Ligand [52] & $\begin{array}{l}\text { Immune cell expression or experimental } \\
\text { model }\end{array}$ & Results of receptor signalling & $\begin{array}{l}\text { Reference } \\
\text { number }\end{array}$ \\
\hline
\end{tabular}

123

$124 \quad \mathrm{P} 2 \mathrm{X} 7 \mathrm{R}$ and

P2Y13R

P2Y1R and ADP $>$ ATP P2Y12R

126

\section{P2Y2R $\quad$ UTP $\geq A T P$}

128

(1)

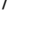

8

39

J774 cells and HEK cells expressing the P2X7 receptor

Human mast cell line HMC-1 and rat basophilic leukaemia cell line (RBL-2H3) with and without transfection of P2Y13-siRNAs and P2X7-siRNAs

Platelets

Platelets

Neutrophils

Neutrophils and fibroblasts

Monocyte-derived DCs (moDCs), eosinophils

Eosinophils

Peritoneal macrophages (RPMs) isolated from resting C57/BL6 mice

Murine model of cutaneous leishmaniasis

$\mathrm{ChAT}^{\mathrm{BAC}}$-eGFP mice

$$
\begin{array}{cc}
\mathrm{P} 2 \mathrm{Y} 4 \mathrm{R} \text { and } & \mathrm{UTP} \geq \mathrm{ATP} \\
\mathrm{P} 2 \mathrm{Y} 12 & \mathrm{ADP}>\mathrm{ATP} \\
\mathrm{respectively} \\
\mathrm{P} 2 \mathrm{Y} 6 \mathrm{R} & \mathrm{UDP}>\mathrm{UTP}>>\text { ATP }
\end{array}
$$

Microglial cells

Neutrophils

Human leukaemia monocytic cell line THP-1 cells

Macrophages

Microglial cells

Microglial cells

Microglial cells

Basophils

Plasmacytoid DCs

Tissue cells receptor for central T-cells) independent from the $\mathrm{NAD}^{+}$-induced ART2-P2X7 pathway

Promotes the formation of pores permeable [227] to very large ions leading to cytolysis

P2Y13R mediates nanomolar mechanical-induced ATP release. P2X7R mediates micromolar mechanical-induced ATP release

$\mathrm{P} 2 \mathrm{Y} 1 \mathrm{R}$ and $\mathrm{P} 2 \mathrm{Y} 12 \mathrm{R}$ synergistic action in thrombin-induced platelet activation

C-activation of P2Y1R and P2Y12R by ADP upregulates the expression of $\mathrm{P}$-selectin (CD62P)

Synergistic AdorA3 and P2Y2R neutrophil [146, 147] chemotaxis (see under AdoRA3 above)

Mediates recruitment of neutrophils into the lungs, proliferation and migration of lung fibroblasts and IL-6 production

Promotes chemotaxis

Induces VCAM-1 expression

P2Y2R-Induced c-Jun N-terminal kinase (JNK) activation is responsible for Increased in IL-1

$\beta$ production

Induces CASP-1 activation and IL-1 $\beta$ secretion during $L$. amazonensis infection. IL- $1 \beta / I L-1 R$ signalling is crucial for P2Y2R-mediated protective immune response in an experimental model of cutaneous leishmaniasis

Elicits tracheal brush cells generation of cysteinyl leukotrienes. Aeroallergens elicit P2Y2-dependent tracheal brush cells cysteinyl leukotrienes generation and tracheal brush cells -dependent airway eosinophilia

P2Y4R and P2Y12R synergistic action increases microglial chemotaxis

Induces neutrophil activation and extracellular trap formation

Induces IL- $1 \beta$ release

Induces MCP-3(CCL7) expression in response to necrotic tissue cells

Facilitates phagocytosis

Induces the expression of MCP-1 (CCL-2)

Promotes phagocytosis

UDP promotes IgE-dependent degranulation

UDP and UTP strongly inhibit IFN-alpha secretion induced by influenza virus or CpG-A

Induces IL-1 $\alpha$, IL-8/CXCL8 and IL-6 re- $\quad[240,248$, lease 
Table 2 (continued)

Effects of extracellular nucleotides and nucleoside on the innate and adaptive immune system through different purinergic receptors

\begin{tabular}{|c|c|c|c|c|c|}
\hline $\begin{array}{l}\text { Row } \\
\text { number }\end{array}$ & Receptor & Ligand [52] & $\begin{array}{l}\text { Immune cell expression or experimental } \\
\text { model }\end{array}$ & Results of receptor signalling & $\begin{array}{l}\text { Reference } \\
\text { number }\end{array}$ \\
\hline
\end{tabular}

144

145

146

\begin{tabular}{|c|c|c|c|}
\hline 147 & P2Y11R & ATP & Neutrophils \\
\hline 148 & & & Neutrophils \\
\hline 149 & & & Neutrophils and moDCs \\
\hline 150 & & & moDCs \\
\hline 151 & & & moDCs \\
\hline 152 & & & Monocytes \\
\hline 153 & $\mathrm{P} 2 \mathrm{Y} 12 \mathrm{R}$ & $\mathrm{ADP}>\mathrm{ATP}$ & Monocytes \\
\hline 154 & & & Vascular smooth muscle cells \\
\hline 155 & & & DCs \\
\hline 156 & & & Microglial cells \\
\hline 157 & & & Microglial cells \\
\hline 158 & & & Microglial cells \\
\hline 159 & & & $\begin{array}{l}\text { Murine model of sepsis, caecal ligation and } \\
\text { puncture (CLP). Co-cultures of human } \\
\text { platelets and T-cells with or without } \\
\text { anti-CD3/CD28 }\end{array}$ \\
\hline 6 & & & Male C57BL/6 mice microglial cells \\
\hline
\end{tabular}

161

162
Tissue cells

Wild-type C57BL/6 mice and their DCs

Institute of Cancer Research (ICR) mice, primary microglial cells and neurons from Sprague Dawley rat

Male C57BL/6 mice microglial cells
Induces IFN- $\beta$ release

Inhibits the maturation and activation of DCs via suppressing the activation of the transcription factor NF- $\mathrm{kB}$. In-vitro studies show that $\mathrm{P} 2 \mathrm{Y} 6$ signalling inhibits the production of IL-12 and IL-23 and the polarisation of Th1 and Th17 subsets mediated by DCs. Mice lacking P2Y6 develop more severe experimental autoimmune encephalomyelitis compared with wild-type mice

Transient middle cerebral artery occlusion (tMCAO) increases P2Y6R expression. P2Y6 receptor-specific inhibitor blocked the phagocytosis of primary microglia under LPS and UDP stimulation. P2Y6 receptor-specific inhibitor down-regulates myosin light-chain kinase (MLCK) required for the cytoskeletal remodelling for the formation of the phagocytic cup. Inhibition of P2Y6R does not reduce the tMCAO-induced upregulation of mRNA levels of IL- $1 \alpha$, IL- $1 \beta$, IL- 6 , IL- 10 , TNF- $\alpha$ and TGF- $\beta$ Inhibits neutrophil apoptosis

Enhances chemotactic response

Induces maturation of the granulocytic progenitors and monocyte differentiation

Inhibits migratory capacity

Induces IL-8 release

Autocrine differentiation towards M1 macrophages, induces IL- $1 \beta$, IL-6, IL-12 and TNF- $\alpha$ release

Increases monocyte adhesion

Upregulates MCP-1 (CCL-2)

Increases antigen endocytosis with subsequent enhancement of specific T-cell activation

Induces movement of juxta-vascular microglial processes to close the injured blood-brain barrier (BBB) and microglial activation

Promotes migratory, inflammatory (TNF- $\alpha$ and IL- 6 release) responses

ADP treated microglial cells induces CCL3 [265] expression in activated T-cells

Blockade of the P2Y12 signalling pathway [266] restrains Treg proliferation in vivo and in vitro

Mediates microglial activation via Ras homolog family member A/Rho-associated protein kinase (RhoA/ROCK) pathways

Inhibits ATP release 
Table 2 (continued)

Effects of extracellular nucleotides and nucleoside on the innate and adaptive immune system through different purinergic receptors

\begin{tabular}{|c|c|c|c|c|c|}
\hline $\begin{array}{l}\text { Row } \\
\text { number }\end{array}$ & Receptor & Ligand [52] & $\begin{array}{l}\text { Immune cell expression or experimental } \\
\text { model }\end{array}$ & Results of receptor signalling & $\begin{array}{l}\text { Reference } \\
\text { number }\end{array}$ \\
\hline
\end{tabular}

NLRP3 inflammasome activation, increased expressions of NLRP3, ASC, active Caspase- 1 and downstream active IL-1 $\beta$. Therefore, increases resistance to monosodium urate-induced acute gouty arthritis. Decreased AMP reverses the in-vivo and in-vitro protective effect of P2Y14R knockout

163. Coronaviruses can induce inflammation by the activation of the intracellular sensing molecules IRIG1/MDA5 [285, 286]. Reportedly, acute inflammation [69, 70] and infection with SARS-CoV-2 virus induce ATP release [287]. The vesicular exocytosis-mediated release of ATP, connexin-43 (Cx43)-mediated ATP release and pannexin-1 (Panx-1)-mediated ATP release can be triggered by the activation of Toll-like receptor 4 (TLR4) and TLR2 by pathogen-associated molecular patterns (PAMPs) and by the activation of P2X7Rs [180-182, 187]. In turn, activation of the P2X7Rs upregulates the protein expression of TLR 2, TLR3, TLR4 and TLR 5 [288]. Additionally, increased levels of TNF- $\alpha$ during inflammation induce ATP release via Panx-1 [289]. Proinflammatory immune response is initiated by the increase in the extracellular ATP, ADP and adenosine levels in the microenvironment of immune cells activating the P2XRs, P2YRs and AdoRs (Fig. 3) [57, 60, 169, 290]. In this case, ATP acts as a danger-associated molecular pattern (DAMP) [291, 292]. Increased ADP levels promote platelet activation and intravascular thrombosis (Table 2, rows 125 and 126). Reportedly, the pathological changes in the lung in patients with COVID-19 pneumonia showed marked microvascular thrombosis [293]. The $\mathrm{EC}_{50}$ for AdoRs is in the range of $26 \mathrm{nM}$ to $1.4 \mu \mathrm{M}$ [281] and for ATP, UTP or ADP receptors (P2XRs and P2YRs with the exception of the P2X7R) in the range of $0.01 \mathrm{nM}$ to $10 \mu \mathrm{M}$ [284, 294]. Obviously, the extent of the cellular ATP release is proportional to the severity of the infection. A severe infection with SARS-CoV-2 causes massive extracellular ATP release by the infected cells. This may be confined to the airway mucosa and the lung or may be extensive in multiple organs. Although increased extracellular ATP concentrations upregulate the expression of ectonucleotidases [295] these high ATP concentrations exceed the capacity of these ecto-enzymes (CD39, CD73, etc.) to clear the extracellular space from ATP molecules [60] ending in ATP concentrations of $>1$ $\mathrm{mM}$. This is demonstrated in a report where the authors show that TLR-mediated CD39 internalisation (causing the deactivation of the ecto-enzyme CD39) in mice bone marrow-derived dendritic cells (BMDCs) leads to the accumulation of extracellular ATP to $1.4 \mathrm{mM}$ [296]. The activation of $\mathrm{P} 2 \mathrm{X} 7 \mathrm{Rs}$ in ongoing inflammation is the hallmark of severe pro-inflammatory immune response (Table 2, rows 74, 86-119 and Fig. 3) [297] including COVID-19 [298]. If these levels of extracellular ATP are accompanied by the absence of the required fluctuations for other purinergic receptor to recover from desensitisation, all P1 and P2 (other than P2X7) purinergic receptors will become fully desensitised demarcating the initiation of hyperinflammation (Fig. 3 and Table 2, rows 120-123) [279-283].

\section{Hyperinflammation is characterised by the activation of P2X7Rs and desensitisation of other $\mathrm{P} 2$ receptors and AdoRs}

As mentioned above, hyperinflammation starts when fluctuation of the extracellular nucleotides and adenosine no longer occurs and leads to prolonged activation of the P2X7Rs of the immune cells. Prolonged vigorous activation of the P2X7Rs leads to macropore formation and cytolysis with uncontrolled ATP release [222, 223, 227, 299] (Table 2, rows 120-123) causing hyperinflammation with massive pro-inflammatory immune response, massive pro-inflammatory and antiinflammatory cytokine release: the cytokine storm (Fig. 3). In the early phase of COVID-19, hyperinflammation may be confined to the site of viral entry (i.e. airway mucosa and conjunctivae) but as viral replication and viral spreading progress, systemic hyperinflammation devel ops. 


\section{Clearance of extracellular ATP}

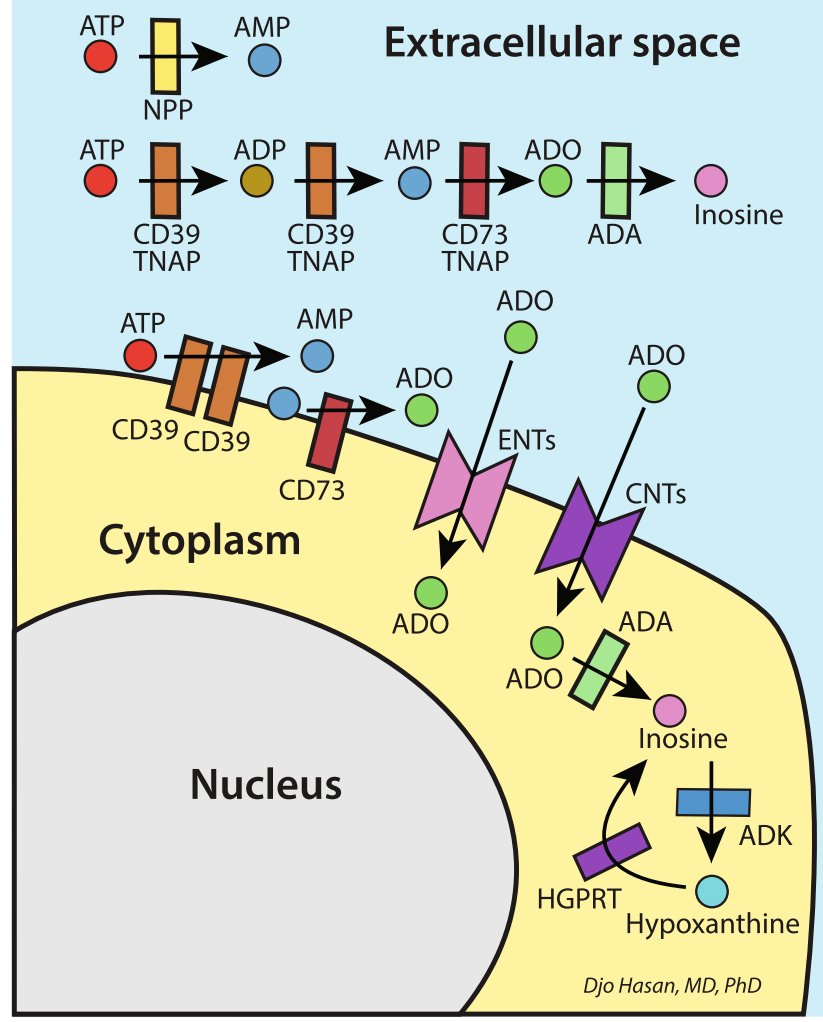

Fig. 2 Clearance of extracellular ATP and adenosine by ectonucleotidases and soluble extracellular nucleotidases [272-274275]. This process is indispensable to enable receptors to recover from desensitisation following receptor activation (resensitisation, see text under the heading "Purinergic signalling in inflammation and hyperinflammation" for explanation). CD39, Ecto-nucleoside triphosphate diphosphohydrolase 1-3 (ENTPD 1-3); CD73, Ecto-5'-nucleotidase (5'-NT); NPP, $n$ ucleotide pyrophosphatase/phosphodiesterase; TNAP, $t$ issue nonspecific alkaline phosphatase; ADA, adenosine deaminase; ADK, adenosine kinase; HGPRT, hypoxanthine-guanine phosphoribosyltransferase; ATP, $a$ denosine triphosphate; ADP, $a$ denosine diphosphate; AMP, adenosine monophosphate; ADO, adenosine; ENTs, equilibrative nucleoside transporters; CNTs, concentrative nucleoside transporters

The upregulation of the expression of ectonucleotidases also leads to an increase in the concentrations of other nucleotides (i.e. ADP) and adenosine. These high extracellular concentrations of nucleotides and adenosine do not show concentration fluctuations required for the recovery (resensitisation) time from desensitisation causing a state of persistent desensitisation of all P2XRs, P2YRs [279, 280, 283, 300, 301] and AdoRs [282] with the exception of P2X7Rs. Consequently, the physiological function in the affected organs and inflamma tory response of the immune system are deactivated. This leads to the failure of organ function (i.e. ARDS in the lungs as we reported earlier [61]) and the immune system (immune paralysis) rendering the host susceptible to secondary co-infections(Fig. 3). Sepsis-induced immunosuppression [302, 303] or compensatory antiinflammatory response syndrome (CARS) in critically ill patients [304] was already raised by researchers in 1996 [305] and is a well-known phenomenon in critically ill patients [302]. Secondary bacterial infections occurred in $34.4 \%$ of 274 surviving elderly patients (age over 60 years) with COVID-19 and in $81.7 \%$ of 65 deceased patients [15]. In addition, it was found that 76 co-infections with other respiratory pathogens occurred in another cohort of 354 COVID19 patients (16 of 115 mild cases (13.9\%), 33 of 155 severe cases $(21.3 \%)$ and 27 in 84 critical cases (32\%)) [16]. In a meta-analysis involving 118 scientific reports on patients with COVID-19, co-infection with other pathogens at admission was observed in $19 \%$ and superinfection with other pathogens during admission in the hospital in $24 \%$ [306].

\section{Control of hyperinflammation is annihilated by the downregulation of Tregs through the activation of P2X7R and the desensitisation of adenosine receptors}

Tregs are key elements in the control of hyperinflammation [307]. Activation of AdoRA2As promotes the differentiation of naïve T-cells towards regulatory T-cells(Tregs) [112], increases the frequency of Tregs and the expression of CTLA-4 receptor and upregulates ecto-enzymes CD39 and CD73 expression accelerating adenosine generation from extracellular ATP [118] (Table 2, rows 25, 29, 30 and 33). This process is upset in case of desensitisation of AdoRs. In addition, activation of P2X7Rs inhibits the suppressive potential and stability of Tregs, inhibits the clonal expansion of Tregs, promotes Treg death, induces Treg depletion and reduces Treg IL-10 production (Table 2, rows 86-88, 106 and 107). In COVID-19 patients, significant lower Treg frequencies [308-310], lower expression of forkhead box protein $\mathrm{P} 3$ (FoxP3), lower expression of transforming growth factor- $\beta$ (TGF- $\beta$ ) and lower cytokine TGF- $\beta$ secretion [309] are observed compared to healthy control. Additionally, a reduced proportion of specific SARS-CoV-2-reactive Tregs was reported [311]. The desensitisation of AdoRs and the activation of P2X7Rs may well be the underlying mechanism of the low Tregs frequency in severe and critically ill COVID-19.

\section{P2X7R antagonist restores the reduced Tregs population and Tregs function in hyperinflammation}

As stated above, infected cells release ATP into the extracellular space. Obviously, the P2X7R antagonist blocks the activation of the P2X7Rs. Because a significant proportion of the ATP release to the extracellular space is mediated by the P2X7R (Table 2, rows 77-79), P2X7R a ntagonism combined with the upregulated ATP hydrolysing activity of the ectoenzymes results in the decrease of the extracellular ATP concentrations. This can potentially abrogate hyperinflammation 


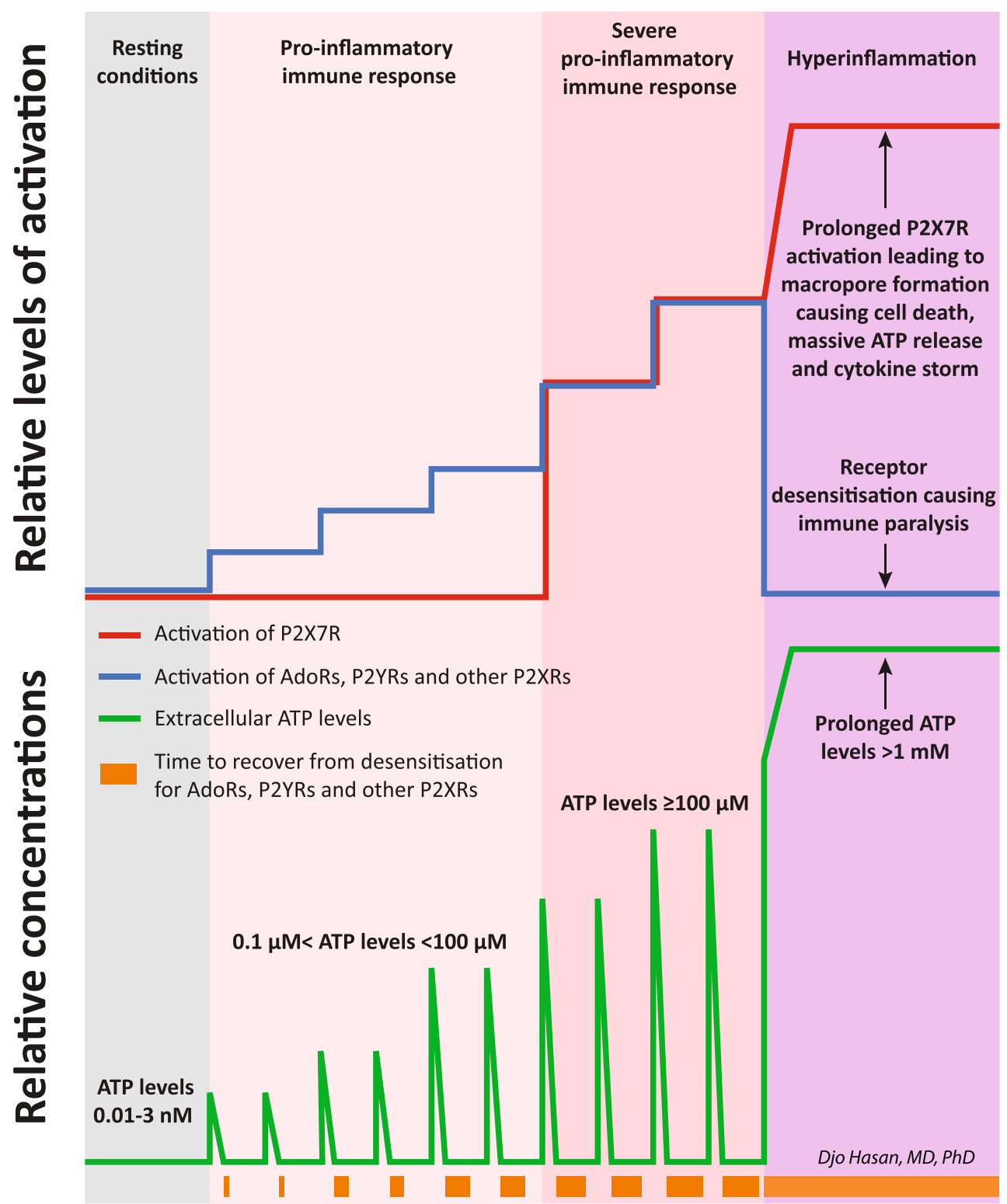

Fig. 3 A schematic presentation of the activation of the purinergic receptors of the immune cells causing a pro-inflammatory response leading to hyperinflammation. Viral infection drives the controlled cellular release of ATP molecules. Increased extracellular nucleotides levels activate P2XRs and P2YRs. Upregulation of the extracellular ATP hydrolysing enzymes as depicted in Fig. 2 results in the increase of extracellular adenosine levels followed by the activation of the adenosine receptors (AdoRs). These processes initiate the physiologic pro-inflammatory response of the immune system. The green line at the bottom of the graph represents the extracellular ATP levels. The ascending part is caused by the ATP release, and the descending part results from the clearance of ATP by the extracellular or membrane-bound ATP hydrolysing enzymes. As the disease progresses and extracellular ATP levels increase above 1 $\mathrm{mM}$, the P2X7R is additionally and effectively activated leading to a severe immune response. Except for P2X7Rs, all these receptors are known to be subject to desensitisation. Desensitisation of a receptor is defined as being unresponsive to activation by the ligand, resulting in (near) zero transmembrane signal transduction. A certain extent of desensitisation occurs after every activation, and this desensitisation requires time to return to the state of complete resensitisation. Increasing intensity and duration of the activation stimuli leads to increasing extent of desensitisation and duration of the recovery time to the state of complete resensitisation (represented by brown boxes with increasing size at the bottom of the graph). Severe viral infection can increase the controlled ATP release beyond the capacity of the extracellular enzymes to clear ATP and adenosine molecules. This causes a sustained high extracellular ATP and adenosine levels preventing the purinergic receptors from recovering from the state of desensitisation. The capacity to clear invading microorganisms diminishes leading to immune paralysis. In addition, prolonged high extracellular levels of ATP and activation of the P2X7R lead to macropore formation and cell death with uncontrolled release of ATP. In turn, this leads to vigorous activation of the P2X7R of the immune cells promoting massive production of cytokines ending in a cytokine storm and hyperinflammation 
and the concomitant immune paralysis. Moreover, P2X7R inhibition promotes the cell-autonomous conversion of CD4+ T cells into Tregs after stimulation of their T-cell receptors (TCRs) [190]. In addition, P2X7R knock-out mice, mimicking the state of complete P2X7R inhibition, show an increase in tissue Tregs, prevent Tregs death and the Tregs produce more IL-10 and TGF- $\beta$ [191]. Experimental inhibition of P2X7Rs restores the Tregs levels and function (Table 2, rows 86-88, 106 and 107) [190-192]. Inhibition of the P2X7R or P2X7R knock-out can attenuate severe inflammation in abdominal sepsis [312] and in acute lung injury $[313,314]$. Apparently, amelioration of hyperinflammation by P2X7R inhibition is based on the increased activation and clonal expansion of the anti-inflammatory Tregs population (Table 2, rows 86-88, 106 and 107).

Some authors proposed that the P2X7R is an ideal candida te to target in COVID-19-associated severe pneumonia [298, 315], and others suggested that hyperactivation of the P2X7R plays a key role in the neuropathology of COVID-19 and that P2X7R antagonism may prevent or treat neurological manifestations of COVID-19 [316].

\section{Lidocaine is a P2X7R antagonist}

In 2015 it was discovered that lidocaine is a P2X7R antagonist [74], and therefore, lidocaine can potentially reduce the clinical symptoms of hyperinflammation significantly. In experimental sepsis, lidocaine improves organ failure [317-319] and survival [317]. In septic patients, lidocaine reduces neutrophil recruitment by the mitigation of chemokine-induced arrest and transepithelial neutrophil migration [320]. Neutrophil recruitment is an important facilitating process in the pathogenesis of multiple organ failure [320] and hyperinflammation in COVID-19 [321-324]. In patients with skin lesions from atopic dermatitis, lidocaine increases the proportion of Tregs and upregulates the FoxP3 expression [325]. In addition, lidocaine increases the IL-10 levels in mechanically ventilated mice [326] and decreases the TNF- $\alpha$ in BAL, plasma and lung samples in pigs undergoing surgery for lung resection [327].
The P2X7R antagonist dose-response relationship of lidocaine is presented in Fig.4. The $\mathrm{IC}_{50}$ for the inhibition of the P2X7R by lidocaine is about $66.07 \mu \mathrm{g} / \mathrm{ml}(0.28 \mathrm{mM})$ [74] where $\mathrm{IC}_{50}$ is defined as the required extracellular concentrations of the receptor antagonist to reach an inhibitory effect of halfway between maximal activation and maximal inhibition (half-maximal inhibitory concentration). The main issue is that the $\mathrm{IC}_{50}$ for P2X7R inhibition is much higher than the maximal tolerable plasma concentration for mammals. The maximal tolerable plasma concentration in humans is about $4.7 \mu \mathrm{g} / \mathrm{ml}(0.02 \mathrm{mM})$; this corresponds with an $\mathrm{IC}_{10}$ or lower $(<10 \%$ inhibitory concentration, Fig.4). Above this lidocaine plasma concentration, adverse effects in increasing severity occur as presented in Table 3 [328, 329]. Thus, systemic lidocaine plasma concentrations of $>4.7 \mu \mathrm{g} / \mathrm{ml}$ must be avoided [328, 329]. Caveat: The inhibitory concentrations of lidocaine for P2X7R as presented in Fig. 4 are not corrected for the series resistance (in the range of 1-3 $\mathrm{M} \Omega$ ) of the used whole-cell voltage clamp method with two puller microelectrodes [74]. One should bear in mind that after correction for series resistance, the reported inhibitory concentration values including $\mathrm{IC}_{50}$ are expected to be higher [330].

In addition to the $\mathrm{P} 2 \mathrm{X} 7 \mathrm{R}$ antagonist properties, lidocaine is also known to have several other inhibitory pharmacological targets: the voltage-gated sodium channels (VGSC: Nav1.2 [331], Nav1.3 [332], Nav1.4[333], Nav1.5 [334], Nav1.7 [335], 1.8 [336] and Nav 1.9 [337]), the Toll-like receptor 2 (TLR 2) [338], TLR4 [318] and the N-methyl-D-aspartate receptor (NMDAR) [339].

VGSCs conduct sodium ions inward and are essential for the transduction of sensory stimuli, the generation of the action potential and the release of neurotransmitters from sensory neuron terminals. Lidocaine inhibition of VGSCs can effectively reduce pain signalling [340]. In addition, VGSCs are present on dendritic cells (maintain chemokine-induced migration) [341], macrophages (regulate phagocytosis and endosomal $\mathrm{pH}$ during LPS-mediated endosomal acidification) [342], microglia (regulate phagocytosis cytokine release ad migration) [343], neutrophils (regulate attachment,
Table 3 Adverse effects in relation to the plasma concentrations of lidocaine. The maximal tolerable plasma levels for human are about $4.7 \mu \mathrm{g} / \mathrm{ml}$ $(0.02 \mathrm{mmol} / \mathrm{L})$. Serious adverse effects start at $9.84 \mu \mathrm{g} / \mathrm{ml}(0.042$ $\mathrm{mmol} / \mathrm{L})$. Source: Hermanns H et al. [328] and Weinberg $L$ et al. [329]

\begin{tabular}{llll}
\hline Symptoms of toxic plasma levels of lidocaine & \multicolumn{2}{l}{ Lidocaine concentration } \\
\cline { 2 - 4 } & $\mathrm{mmol} / \mathrm{L}$ & $\mu \mathrm{mol} / \mathrm{L}$ & $\mu \mathrm{g} / \mathrm{ml}$ \\
\hline No noticeable symptoms & $<0.020$ & $<20$ & $<4.69$ \\
$\begin{array}{l}\text { Anxiety, dizziness } \\
\text { Decreased spinal reflexes }\end{array}$ & 0.020 & 20 & 4.69 \\
$\begin{array}{l}\text { Central nervous system (confusion, diplopia, nausea and vomiting, twitching } \\
\quad \text { and tremors, seizures with reduced consciousness, respiratory depression, }\end{array}$ & 0.042 & 42 & 9.84 \\
$\quad$ coma, etc.) & & 80 & 18.74 \\
$\begin{array}{l}\text { Cardiac toxicity (bradycardia, hypotension, cardiovascular depression, cardiac } \\
\text { arrest, etc.) }\end{array}$ & 0.130 & 130 & 30.46 \\
Cytotoxicity & 3.0 & 3000 & 702.9 \\
\hline
\end{tabular}




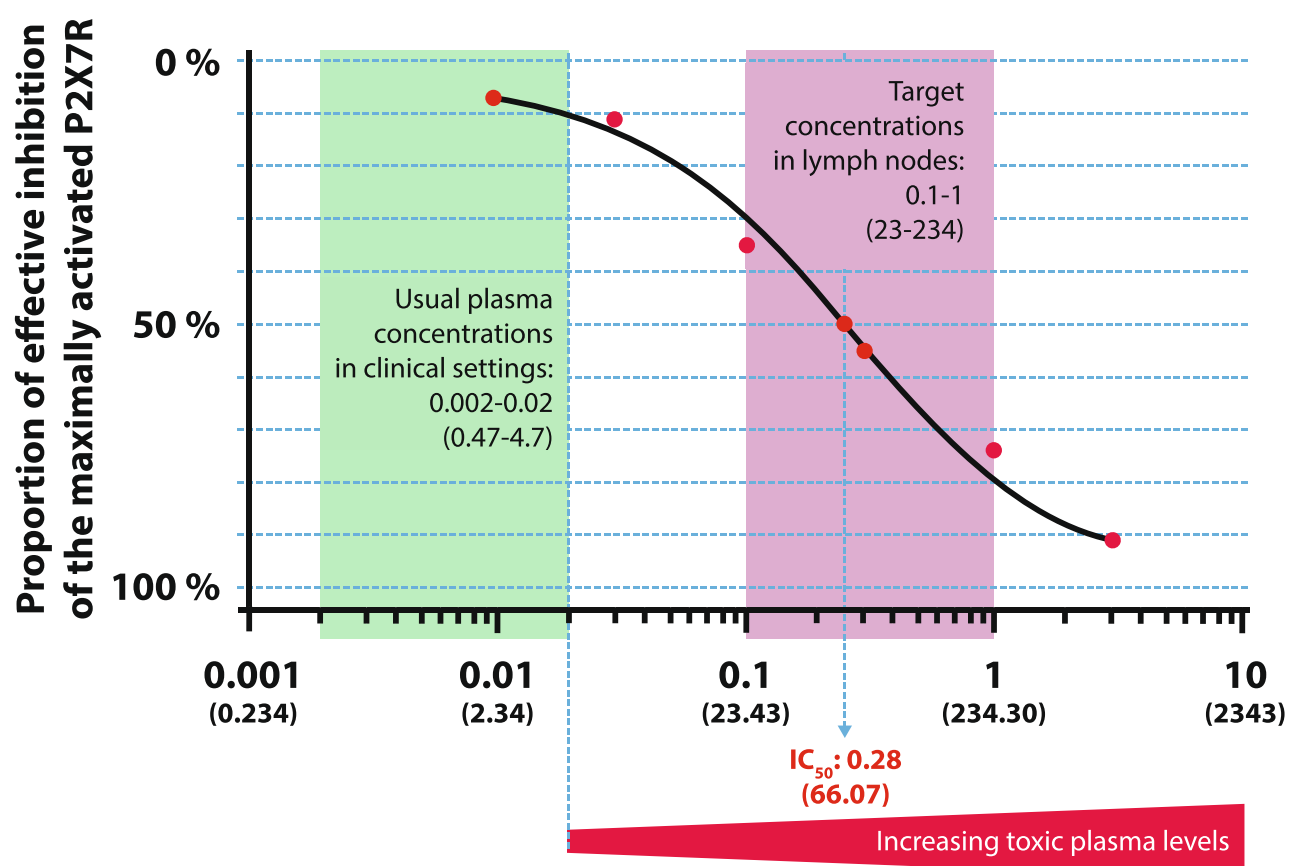

\section{Concentration of extracellular lidocaine in $\mathrm{mmol} / \mathrm{L}(\mu \mathrm{g} / \mathrm{ml})$ logarithmic scale}

Fig. 4 Dose-response relationship of lidocaine suppressing the ATPinduced currents in oocytes expressing P2X7R. We reconstructed the fitted curve from the inhibitory concentrations data of lidocaine for P2X7R from the original article: 7\% inhibition: $0.01 \mathrm{mM}(2.34 \mu \mathrm{g} / \mathrm{ml})$; $11 \%$ inhibition: $0.03 \mathrm{mM}(7.03 \mu \mathrm{g} / \mathrm{ml}) ; 35 \%$ inhibition: $0.10 \mathrm{mM}(23.43$ $\mu \mathrm{g} / \mathrm{ml}) ; 50 \%$ inhibition $\left(\mathrm{IC}_{50}\right): 0.28 \mathrm{mM}(66.07 \mu \mathrm{g} / \mathrm{ml}) ; 55 \%$ inhibition: $0.30 \mathrm{mM}$ (70.29 $\mu \mathrm{g} / \mathrm{ml}) ; 74 \%$ inhibition: $1.00 \mathrm{mM}(234.30 \mu \mathrm{g} / \mathrm{ml}) ; 91 \%$

transmigration and chemotaxis) [344] and T-cells (regulate positive selection of $\mathrm{CD}^{+} \mathrm{T}$ cells) [345]. However, until date no relevant data have been published suggesting that other VGSC antagonists (such as HYP-17 [346], A-803467 [347, 348], PF-05089771 [349], phenytoin [350] or tetrodotoxin [351, 352]) may substitute non-steroidal anti-inflammatory drugs let alone may suppress COVID-19-related hyperinflammation [353]. A plausible reason is that during hyperinflammation-including hyperinflammation in COVID-19 - the cytokine levels (i.e. IL-1 $\beta$ [354], IL-6, IL$10[355,356]$ and IL-12 [357]) are high. Reportedly, IL-1 $\beta$ [358] and IL-6 [359] inhibit sodium currents of VGSCs, and IL-10 downregulates the expression of VCSCs [360]. Moreover, activation of the P2X7R reduced the density and currents of VGSCs [361]. Therefore, we do not consider the inhibitory properties of lidocaine on VGSCs to be relevant for the treatment of hyperinflammation in COVID-19.

At first glance, the downregulation of the expression of TLR 2 [338] and TLR 4 [318] is an important antiinflammatory mechanism directly induced by lidocaine. But at a closer look, it appeared that activation of P2X7R by the agonist cathelicidin (LL-37) leads to the upregulation of the protein expression of TLR2, TLR3, TLR4 and TLR 5 [288]. inhibition: $3.00 \mathrm{mM}(702.90 \mu \mathrm{g} / \mathrm{ml})$; and $98 \%$ inhibition: $10.00 \mathrm{mM}$ $(2343.00 \mu \mathrm{g} / \mathrm{ml})$, respectively. The usual plasma concentrations in clinical settings are indicated by the green box, and the targeted concentrations in the lymph nodes are indicated by the magenta box. Note that the maximal tolerable plasma levels for human (about $4.7 \mu \mathrm{g} / \mathrm{ml}-0.02$ $\mathrm{mmol} / \mathrm{L}$ ) are much lower than the required extracellular concentrations of lidocaine to effectively inhibit the P2X7R. Source: Okura D, et al. [74]
This is in line with the MyD88 (myeloid differentiation primary-response protein 88 )-dependent activation of NF- $\mathrm{KB}$ (nuclear factor kappa-light-chain-enhancer of activated $\mathrm{B}$ cells) following the activation of the P2X7R by BzATP $[362,363]$. The MyD88-dependent activation of NF-KB is part of the TLR4/NF-kB pathway. Therefore, it is unsurprising that the inhibition of P2X7R by its antagonists (Brilliant Blue G, A-438079 and A-740003) neutralises the abovementioned P2X7R-induced upregulation of TLRs [362]. Consequently, we argue that lidocaine inhibits inflammation directly by blocking P2X7Rs independent from the neutralisation of the P2X7R-induced upregulated TLR2 and TLR4.

The subpopulation of NMDA receptors present on the peripheral neurons are involved in nociception, and their number increases during inflammation contributing to the sensitisation of peripheral nerves to nociceptive stimuli. NMDA receptor antagonists have anaesthetic-like effects [364]. In addition, NMDA receptor antagonist can prevent hypoxic neuronal death, IL-1 $\beta$ and TNF $\alpha$ release [365], reduce the activation of inflammatory experimental colitis [366] and suppress glial pro-inflammatory cytokine expression [367]. Moreover, the NMDA receptor antagonist memantine can increase IL-10 
production in BCR/CD40-activatedB-cells [368]. Lidocaine inhibits NMDA receptors $[339,369,370]$, and thus the antiinflammatory properties of lidocaine could be attributed to the inhibition of NMDA receptors. However, it has been reported that the anti-inflammatory effect in T-cell functions (inhibition of antigen-specific T-cell proliferation, T-cell cytotoxicity, Tcell migration towards chemokines and decrease in IL-2 and IFN- $\gamma$ production by Th 1 effector cells in favour of IL- 10 and IL-13 production by Th2 cells) of the NMDA receptor antagonist ifenprodil is effective both in wild-type and in NMDA receptor (GluN1) knockout mice [371]. Moreover, it was found that $\mathrm{KN}-62$, an inhibitor of $\mathrm{Ca} 2+/$ calmodulin-dependent kinase type II and a potent P2X7R antagonist, provides neuroprotection against NMDA-induced cell death [372]. Therefore, we argue that the anti-inflammatory properties of NMDA receptor antagonists (including lidocaine) should be attributed to the inhibition of P2X7Rs rather than to the inhibition of NMDA receptors.

\section{Selective inhibition of the P2X7Rs of the immune cells in the lymphatics avoids exceeding the maximal tolerable plasma concentration of lidocaine and inhibits hyperinflammation in two stages}

As mentioned above, the main issue is that the $\mathrm{IC}_{50}$ for $\mathrm{P} 2 \mathrm{X} 7 \mathrm{R}$ inhibition is much higher than the maximal tolerable plasma concentration for mammals because P2X7Rs are indispensable for normal physiological functions (i.e. in the central nervous system [373], the peripheral nervous system [374] and in the lungs [60, 61]). Therefore, intravenous or oral administration aimed at achieving an effective concentration of lidocaine to inhibit P2X7Rs in serum and in target organs will hamper organ functions and is potentially dangerous.

The lymphatic system is populated exclusively by trafficking immune cells, i.e. naïve $\mathrm{T}$ cells, activated $\mathrm{T}$ cells, B cells [375], dendritic cells [376], monocytes [377], macrophages [378], neutrophils [379], mast cells [380], eosinophils [381] and basophils [382]. We postulate that selective inhibition of the P2X7Rs of the immune cells of the lymphatic system by lidocaine suppresses hyperinflammation in two stages: stage 1, the selective inhibition of the P2X7Rs of the immune cells residing in the lymph nodes induces clonal expansion of Tregs in these lymph nodes; stage 2, subsequently, these Tregs migrate throughout the body exerting anti-inflammatory activities reducing systemic and (distant) local hyperinflammation (Fig. 1).

The endothelium of the dermal capillaries of the skin belongs to the structural type "continuous endothelium" [383]. Although capillary walls can transport substances from blood to tissue, the absorption of substances from tissue to blood is, if any, extremely low [384]. Apparently, specialised initial lymphatics harbouring one-way valve leaflets capable of absorbing fluid and molecules from the interstitium are localised in the dermis. The absorbed lymph fluid is then propelled forward in the lymphatic network by collecting lymphatic vessels harbouring a rhythmic contracting muscle layer [385]. This system brings fluids and particles into the lymph nodes where numerous immune processes take place. The administration route to target the lymphatic system in a domestic swine model is illustrated by the subcutaneous or intradermal injection of compounds (isosulfan blue, fluorescein and radioactive technetium- 99 isotope $-\mathrm{Tc}^{99}$ ) and by tracing the extent and the transit time of the distribution of these compounds using whole body scintigraphy in pigs [386]. The absorption of intradermal application of radioactive $\mathrm{Tc}^{99}$ into the lymph nodes is 10 times faster than after deep subcutaneous application and leads to higher concentrations in the lymph nodes related to these lymphatic vessels [386]. Radionuclide lymphoscintigraphy with molecules of different sizes after intradermal and subcutaneous injections showed that smaller particles (i.e. $99 \mathrm{mTc}$-dextran and $99 \mathrm{mTc}$-human serum albumin) migrate more rapidly towards the lymphatic vessels and lymphatic nodes than larger particles (i.e. radiocolloids of larger molecular size) [387]. The rate of clearance of ${ }^{99 \mathrm{~m}} \mathrm{Tc}$-pertechnetate and ${ }^{99 \mathrm{~m}} \mathrm{TcDTPA}$ after subcutaneous and intradermal administration in the back of the hand in humans is $1 \% / \mathrm{min}$ and 8 to $10 \% / \mathrm{min}$, respectively [387].

The additional advantage is that the plasma concentrations of subcutaneously administered lidocaine are much lower than intravenously administered lidocaine. Intravenous administration of $2 \mathrm{mg} / \mathrm{kg}$ lidocaine in cats is almost immediately followed by a peak plasma concentration of $3.6 \mu \mathrm{g} / \mathrm{mL}$ [388]. In contrast, the achieved mean peak plasma concentrations after the subcutaneous administration of $30 \mathrm{mg} / \mathrm{kg}, 20 \mathrm{mg} / \mathrm{kg}$ and $10 \mathrm{mg} / \mathrm{kg}$ lidocaine are much lower: $1.69,1.07$ and $0.77 \mu \mathrm{g} / \mathrm{mL}$, respectively [389]. Note that the applied subcutaneous dose [389] is 15,10 and 5 times higher than the intravenous dose, respectively [388, 389]. Reportedly, the difference in the plasma concentrations after intravenous and subcutaneous administration of lidocaine is caused by the fact that, in contrast to the intravenous administration, a large proportion of the subcutaneously administered lidocaine is drained into the lymphatic system [390-392]. Obviously, this slows down the release of lidocaine to the venous blood. This is confirmed for bevacizumab in mice [390], for trastuzumab in rats [391] and for docetaxel in rats by [392].

As stated above, lymphatic absorption after intradermal administration is much higher than after deep subcutaneous administration [386, 387]. Practically, the intradermal infusion with lidocaine is not an accepted administration route for lidocaine. Therefore, we argue that a subdermal administration of lidocaine using a catheter inserted just beneath the dermis (subdermal infusion, Fig. 5) will result in higher 
concentrations of lidocaine in the draining local lymph nodes than a deep subcutaneous or intravenous infusion as depicted in the schematic presentation of the putative distribution of lidocaine in Fig. 6.

In summary, by means of the subdermal administration of lidocaine, we can ensure high concentrations of lidocaine in the local lymph nodes enabling an effective inhibition of the P2X7R of the immune cells while keeping the lidocaine plasma concentrations $<4.7 \mu \mathrm{g} / \mathrm{ml}$ (stage $1 \mathrm{a}$ and $1 \mathrm{~b}$ in Fig. 1). The induced Tregs clonal expansion in these local lymph nodes produces Tregs which migrate throughout the body controlling the ongoing hyperinflammation (stage 2 in Fig. 1). Obviously, the subdermal administration route may also apply to other P2X7R antagonists.

Three other P2X7R antagonists have been tested in human: CE-224,535 500 (Pfizer), AZD-9056(Astra-Zeneca) and JNJ54175446 (Johnson and Johnson). A phase IIa study with CE224,535 in patients with rheumatoid arthritis not responding adequately to methotrexate was recently reported [393]. Patients in the treatment arm received oral CE-224,535 $500 \mathrm{mg}$ twice/day for 12 weeks. Although the safety and tolerability for the compound were acceptable, CE-224,535 was not effective in this group of patients. The results of a phase II study with AZD-9056 in patients with active rheumatoid arthritis despite treatment with methotrexate or sulphasalazine was published. The treatment arm consists of oral AZD-9056 100 or $400 \mathrm{mg} /$ day for 6 months [394]. The AZD-9056 used in this trial is non-lipophilic as indicated by the fact that this compound cannot penetrate the blood-brain barrier [395]. The authors conceded that "AZD-9056 does not have significant efficacy in the treatment of RA, and the P2X7 receptor does not appear to be a therapeutically useful target in RA" [394]. Recently, a randomised, placebo controlled, sequential-group, single-centre ascending dose phase I study was reported. The patients in the 5 treatment arms received $0.5,2.5,10,50,150$ and $300 \mathrm{mg} \mathrm{JNJ}-54175446$, respectively. The authors reported dose-dependent plasma levels, no serious adverse events, ex vivo attenuation of lipopolysaccharide-induced IL- $1 \beta$ release in peripheral blood and confirmation of passive brain penetration of JNJ-54175446 [396]. The approach of the P2X7R antagonist therapy of the above-mentioned authors is quite different from ours: While these authors directly targeted the diseased organs via the gut absorption of the drug, we target the immune cells in local lymph nodes inducing an anti-inflammatory immune response which in turn targets the diseased organs (Fig. 1). This is illustrated by the following study concerning a placebo-controlled, multicentre, doubleblind phase IIa study in patients with moderately to severely active Crohn's disease. The patients in the treatment arm received oral AZD-9056 $200 \mathrm{mg} /$ day for 28 days. The authors found a significant improvement in the Crohn's Disease Activity Index (CDAI) at day 28 [397]. In contrast to the skin, the endothelium of the mucosal capillaries of the mouth and the gastrointestinal tract are fenestrated allowing molecules to pass from the submucosal tissue into the capillaries [383]. Unlike the failure of the treatment of rheumatoid arthritis described above, the successful treatment of gut inflammation here can be attributed to the absorption of non-lipophilic oral AZD-9056 by the mucosa-associated lymphoid tissue (MALT). This is the inductive site of the mucosal immune system consisting of mesenteric lymph nodes, Peyer's patches and isolated lymph follicles [398, 399]. Although lymphatic transport to the lymph nodes of the non-lipophilic oral AZD-9056 is limited [400, 401], AZD-9056 inhibits P2X7Rs of the local T-cells via absorption by the inductive sites of MALT. This induces a local anti-inflammatory immune response executed by the effector sites of MALT consisting of lamina propria lymphocytes and intraepithelial lymphocytes [398, 399].

Fig. 5 The cannula for subdermal infusion of lidocaine is superficially positioned just below the dermis to promote the uptake of lidocaine by the initial lymphatics of the dermis and to avoid accumulation of lidocaine in the subcutaneous fat tissue

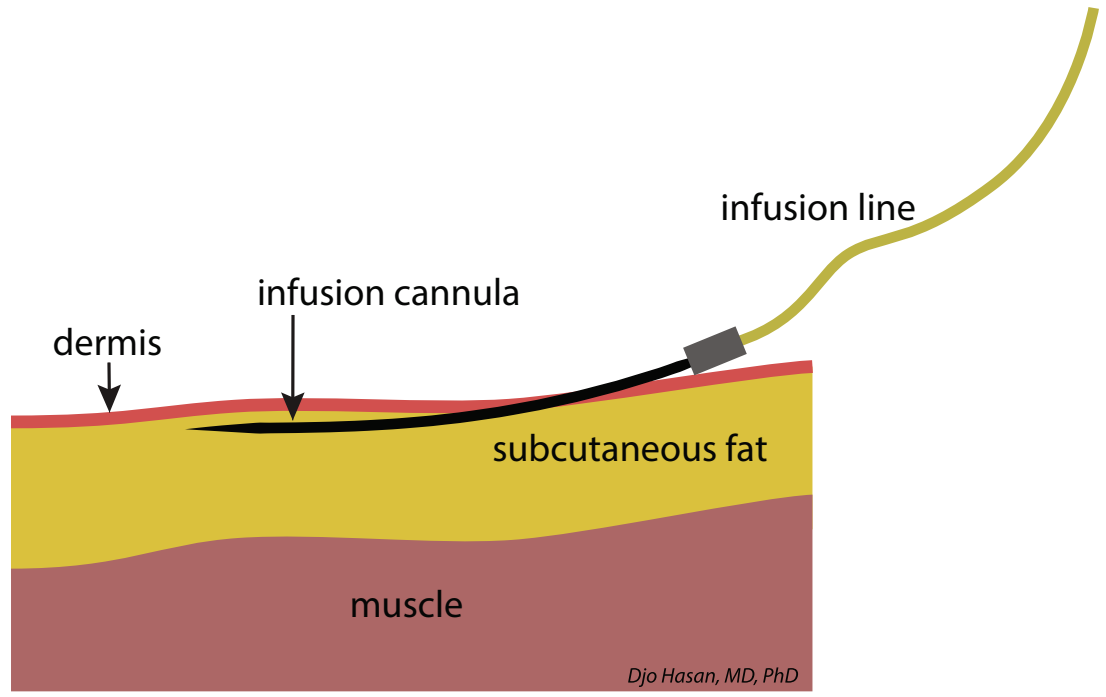


Schematic presentation of the putative distribution of lidocaine (or of any other P2X7R antagonist) shortly after administration

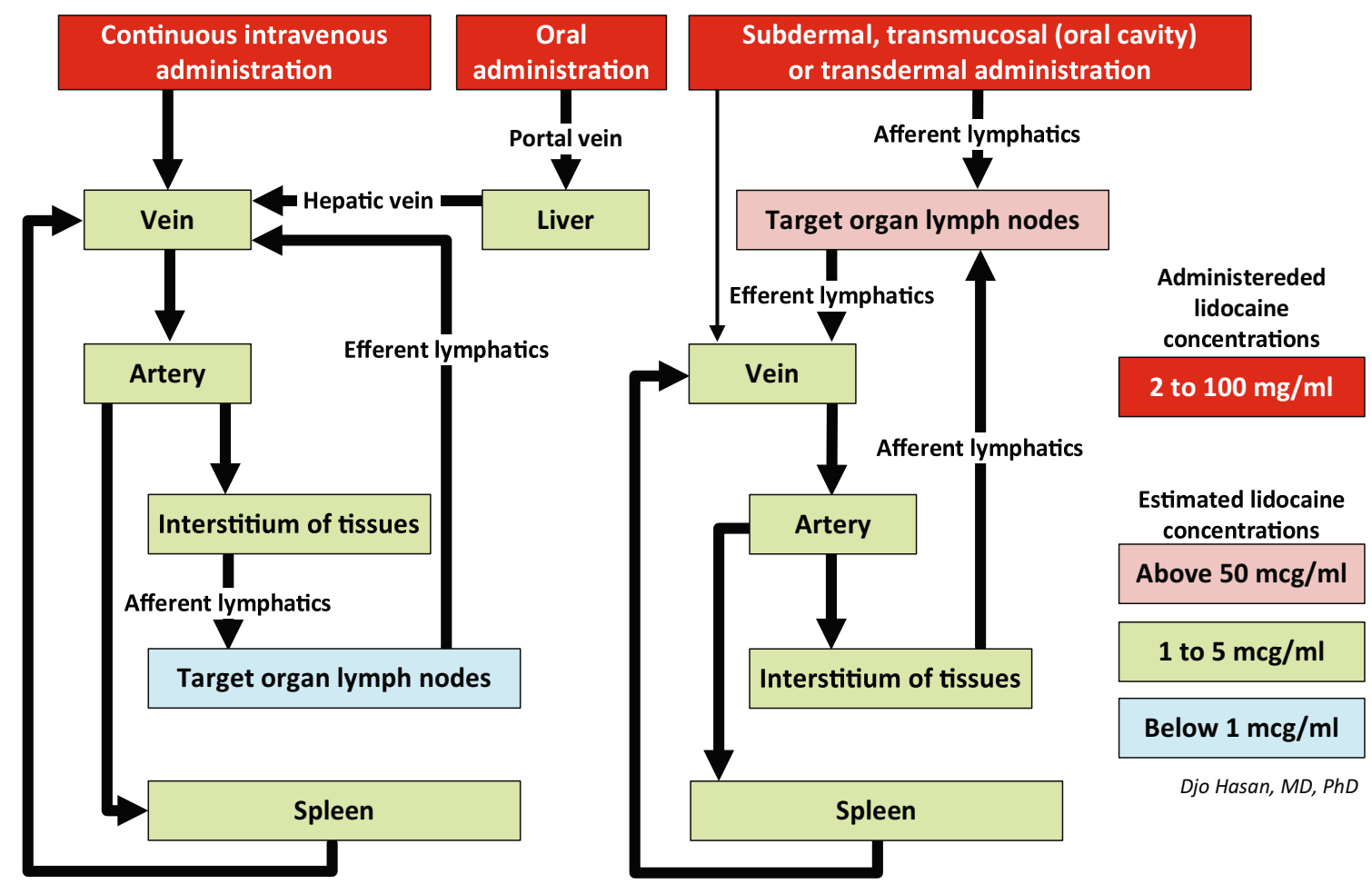

Fig. 6 Schematic presentation of the putative distribution of intravenous, oral, transmucosal (i.e. in the oral cavity) and subdermal administered lidocaine. Administration of hydrophilic lidocaine (lidocaine HCL) through a (central) venous catheter or by oral intake results in concentration gradients with the highest value in the venous blood and the lowest value in the lymph nodes. The reason is that by the time lidocaine reaches the lymph nodes, the drug is massively diluted and may never reach the effective concentration required to adequately inhibit the P2X7Rs of the immune system. In contrast, after subdermal injection of hydrophilic lidocaine, apart from a minimal absorption by the dermal capillaries, almost all the lidocaine is absorbed by the lymphatic system via the initial lymphatics. Because the fluid in the afferent collecting lymphatics originates from the interstitial fluid of the tissues, dilution of the concentration of lidocaine occurs. This fluid is then drained into the local lymph nodes. The extent of the dilution of lidocaine in the targeted lymph nodes is far less drastic compared to the (central) venous administration of the drug. We postulate that with continuous subdermal infusion, we can achieve concentrations of lidocaine in the lymph nodes sufficient to effectively inhibit the P2X7Rs of the immune cells. Theoretically, similar results may be expected from transmucosal and transdermal administration of lipophilic lidocaine base with a high concentration. Obviously, the subdermal, transmucosal and transdermal administration routes may also apply to other P2X7R antagonists

\section{Real-world subdermal administration of lidocaine in critically ill COVID-19 patients}

\section{Six COVID-19-induced ARDS patients}

From April 2020 until end of July 2020, two of the authors of this report (AS and TK) have successfully treated six critically ill patients with COVID-19 admitted to the ICU of the Showa University in Tokyo, Japan, with lidocaine. The lidocaine treatment was based on off-label use. The Medical Ethical Committee of the Showa University, School of Medicine, Tokyo, approved the collection, analysis and publication of patients on mechanical ventilation admitted to the ICU (protocol number 3313). The administration was initially intravenously in the two first patients, followed by subdermally (a superficially inserted subcutaneous catheter as illustrated in Fig. 5). In the other four patients, only the subdermal administration was further applied. The concentration of the intravenous lidocaine infusion solution is $20 \mathrm{mg} / \mathrm{ml}(2 \%)$, the route for continuous administration of lidocaine commonly used in daily practice. The dose for intravenous administration is $0.6 \mathrm{mg} / \mathrm{kg} / \mathrm{h}$ as recommended earlier [402]. Due to the limited efficacy of intravenous lidocaine and based on the hypothesis of selectively targeting the inhibition of the P2X7Rs of the immune cells, the infusion in both patients was converted to subdermal infusion of $1.0 \mathrm{mg} / \mathrm{kg} / \mathrm{h}$ (dosage as reported by Japanese researchers [403]) after 7 and 6 days, respectively. The time course of clinical parameters of these six patients 
is presented in Figures 7, 8, 9, 10. In about 20\% of the inserted subdermal cannulae, local subdermal indurations were observed. Whenever this occurred, the infusion cannula was removed and replaced with a new cannula at a different location.

The first patient (Fig.7), a 63-year-old male (75 kg, 168 $\mathrm{cm}$ ), developed fever and nausea on March 27, 2020, and 3 days later, he started to cough and became dyspnoeic. After 5 days, the PCR SARS-Cov-2 test was positive, and he was admitted to the hospital with SARS-Cov-2-induced ARDS. Co-morbidities include COPD and smoking 60 cigarettes per day for more than 40 years. About 40 years earlier, the patient suffered from pneumothorax. On day 3, the patient deteriorated and was intubated and mechanically ventilated due to poor blood gases. No haemodynamic instability was observed. The CT scan showed bilateral ground glass opacities compatible with ARDS. On day 5, the patient was transferred to the ICU of the university hospital because of further respiratory deterioration. The patient received favipiravir for 14 days after admission; the patient did not receive dexamethasone. Prone position mechanical ventilation was initiated due to the progression of the respiratory disease with an extremely low $\mathrm{PaO}_{2} / \mathrm{FiO}_{2}$ ratio of $63.3 \mathrm{~mm} \mathrm{Hg}$ (severe ARDS according to the Berlin definition. The Berlin definition of ARDS includes severe $\mathrm{PaO}_{2} / \mathrm{FiO}_{2}$ ratio $\leq 100 \mathrm{~mm} \mathrm{Hg}$, moderate $\mathrm{PaO}_{2} / \mathrm{FiO}_{2}>100$ to $200 \mathrm{~mm} \mathrm{Hg}$, mild $\mathrm{PaO} 2 / \mathrm{FiO} 2>200$ to $300 \mathrm{~mm} \mathrm{Hg}$, no ARDS PaO2/FiO2 >300 mm Hg [404]). The initial ventilator settings include APRV, $\mathrm{P}_{\text {high }} 27 \mathrm{~cm}$ $\mathrm{H}_{2} \mathrm{O}, \mathrm{T}_{\text {high }} 7.0 \mathrm{~s}, \mathrm{P}_{\text {low }} 0 \mathrm{~cm} \mathrm{H}_{2} \mathrm{O}$ and $\mathrm{T}_{\text {low }} 0.32 \mathrm{~s}$. The
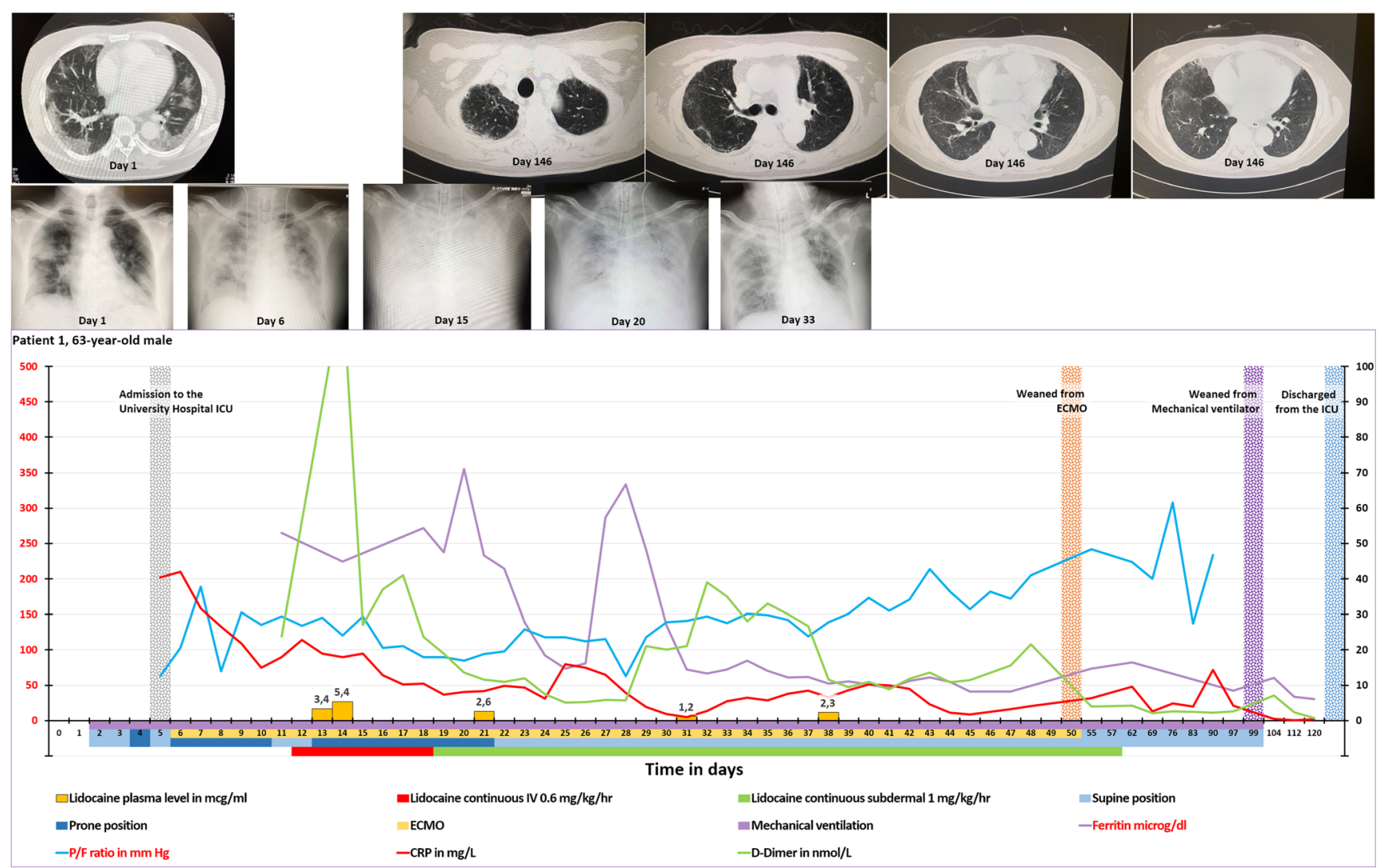

Fig. 7 Patient 1, the first of the six cases with severe COVID-19 treated with subdermal lidocaine in the ICU of the Showa University, Tokyo, Japan. A 63-year-old male with COVID-19-induced ARDS, was admitted to the hospital. The CT scan showed bilateral ground glass opacities. Co-morbidities: COPD, smoking 60 cigarettes per day for more than 40 years. About 40 years before admission, the patient suffered from pneumothorax. After admission the clinical condition deteriorated requiring an ICU admission and mechanical ventilation on day 4. On day 11, continuous intravenous lidocaine of $0.6 \mathrm{mg} / \mathrm{kg} / \mathrm{h}$ was initiated, but the patient's condition kept worsening with high pulmonary artery pressures and reduced aeration of the lung. On day 19, the continuous intravenous lidocaine of $0.6 \mathrm{mg} / \mathrm{kg} / \mathrm{h}$ was changed to continuous subdermal lidocaine of 1 $\mathrm{mg} / \mathrm{kg} / \mathrm{h}$. This was followed by improvement of the clinical condition, and on day 20, the aeration of the lung was improved, but the pulmonary artery pressures remained high. Despite this the $\mathrm{P} / \mathrm{F}$ ratio was gradually improving, and ECMO weaning was done on day 50. No new ECG changes were observed during treatment with lidocaine. Blood metHb were within the normal range (0.3-0.8\%). On day 99, he was weaned from the mechanical ventilator and was discharged from the ICU on day 121. CT scan on day 146 showed reduced ground glass opacities in both lungs and some interstitial change in upper and middle fields of the lung and improvement of the pneumothorax. The patient was discharged from the hospital on day 187, he went home, and he could walk but needed extra oxygen supply of $2 \mathrm{~L} / \mathrm{min}$. Nine months after admission, the patient is doing well and has returned to work. The patient visited the hospital 3 months after discharge: He only uses oxygen $1 \mathrm{~L} / \mathrm{min}$ to go shopping and during physical training (out-patient rehabilitation). He talked to the treating intensivist without requiring oxygen and had no shortness of breath or tachypnoea. The red-coloured labels of the legends refer to graph plots using the (left) primary $Y$-axis, and the black-coloured labels of the legends refer to graph plots using the (right) secondary $Y$-axis 

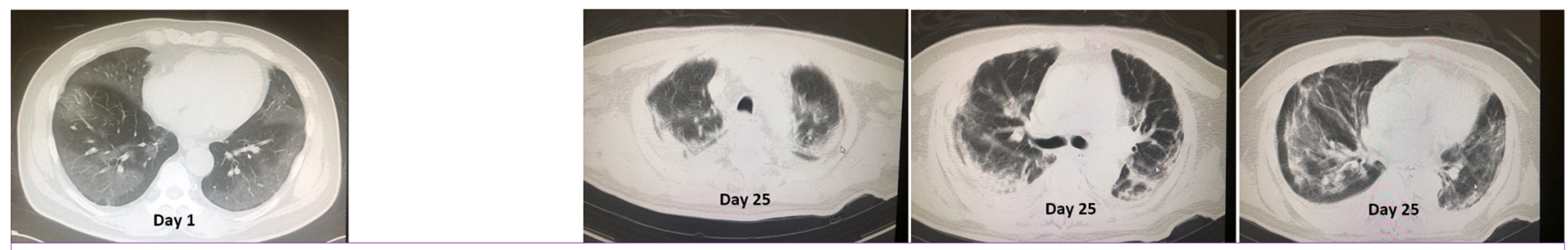

Patient 2, 68-year-old male

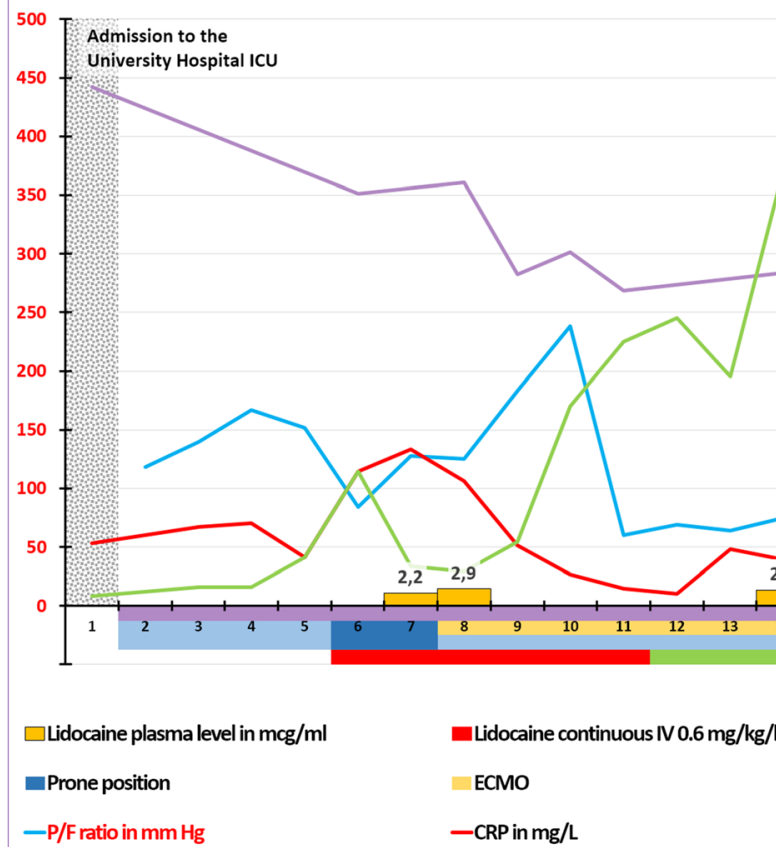

- $\mathrm{P} / \mathrm{F}$ ratio in $\mathrm{mm} \mathrm{Hg}$

- CRP in $\mathrm{mg} / \mathrm{L}$

Fig. 8 Patient 2. A 68-year-old male with COVID-19-induced ARDS admitted to the ICU and required mechanical ventilation. The CT scan showed bilateral ground glass opacities. Co-morbidity: Asthma. After admission the patient's condition was deteriorating. On day 5, continuous intravenous lidocaine of $0.6 \mathrm{mg} / \mathrm{kg} / \mathrm{h}$ was initiated, but the clinical condition and the $\mathrm{P} / \mathrm{F}$ ratio kept worsening. On day 11 , the intravenous lidocaine of $0.6 \mathrm{mg} / \mathrm{kg} / \mathrm{h}$ was changed to continuous subdermal lidocaine of $1 \mathrm{mg} / \mathrm{kg} / \mathrm{h}$. A few days later, this was followed by improvement of the

Time in days

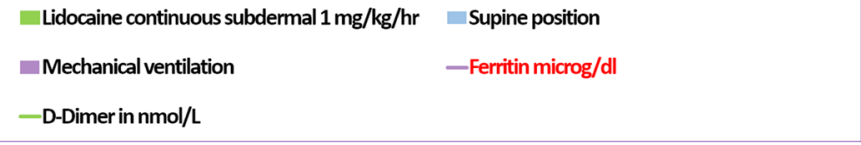

clinical condition and the P/F ratio. No new ECG changes were observed during treatment with lidocaine. Blood metHb were within the normal range $(0.1-0.6 \%)$. The patient was discharged from the ICU on day 30 home on day 37. At 3 months after admission, the patient is doing well. The red coloured labels of the legends refer to graph plots using the (left) primary $Y$-axis, and the black-coloured labels of the legends refer to graph plots using the (right) secondary $Y$-axis

$121.9 \mathrm{nM} / \mathrm{L}$ day 14 . On day 11 , no improvement of the blood gases was observed, and it was decided to treat the patient with continuous intravenous lidocaine $0.6 \mathrm{mg} / \mathrm{kg} / \mathrm{h}$. The CRP showed a progressive decline from 19 (on day 12) to 12.8 (on day 16) and 7.4 (on day 19), but the $\mathrm{PaO}_{2} / \mathrm{FiO}_{2}$ ratio remained poor at around $90 \mathrm{~mm} \mathrm{Hg}$ (severe ARDS according to the Berlin criteria) and the chest X-ray image on day 15, 3 days after the initiation of the intravenous lidocaine infusion, deteriorated dramatically. The lidocaine plasma concentrations were $3.4 \mu \mathrm{g} / \mathrm{ml}$ on day 13 and $5.4 \mu \mathrm{g} / \mathrm{ml}$ on day 14 . On day 19, the continuous intravenous lidocaine infusion was replaced by continuous subdermal lidocaine infusion of $1 \mathrm{mg} / \mathrm{kg} / \mathrm{h}$. Although the $\mathrm{PaO}_{2} / \mathrm{FiO}_{2}$ ratio remained unchanged on day 20 ( 1 day after the switch to the continuous subdermal lidocaine), the chest X-ray improved clearly. On day 21 , the lidocaine plasma concentration was $2.6 \mu \mathrm{g} / \mathrm{ml}$, and albumin was $2.5 \mathrm{~g} / \mathrm{dl}$. From day 22, the $\mathrm{PaO}_{2} / \mathrm{FiO}_{2}$ ratio was gradually improving reaching $151 \mathrm{~mm} \mathrm{Hg}$ on day 34

From day 11 until day 62, D-Dimer was very high reaching 


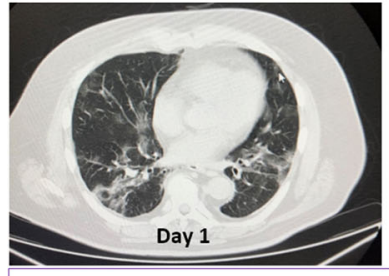

Patient 3, 59-year-old male

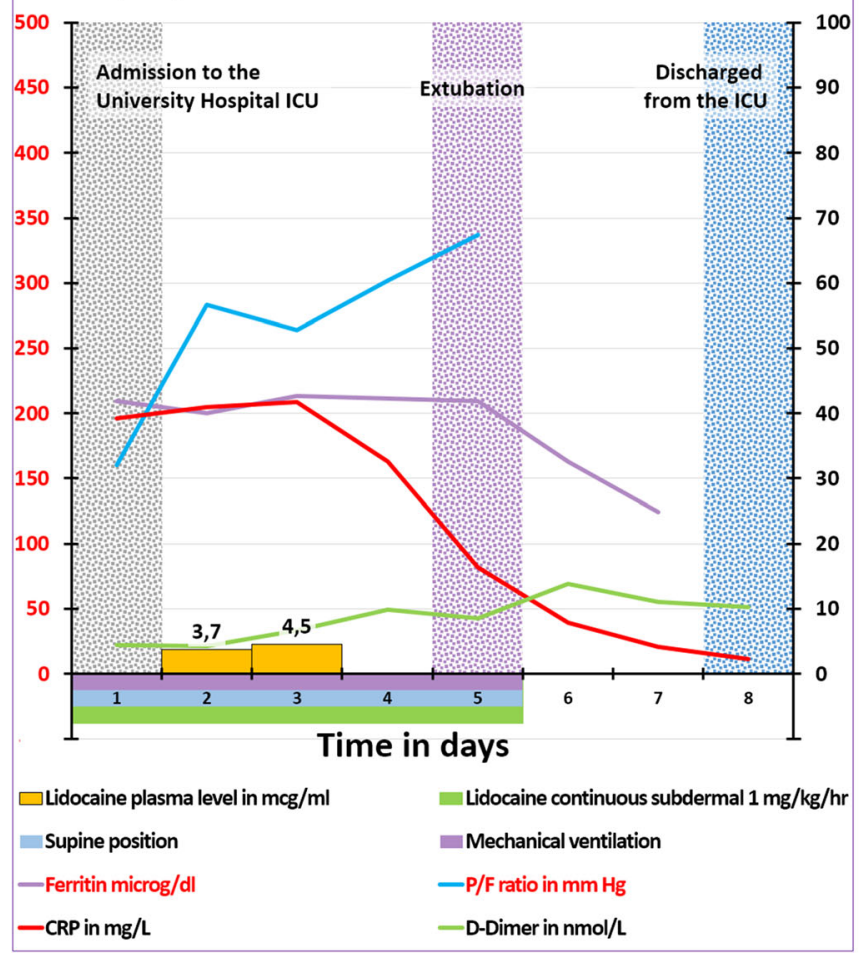

Fig. 9 Left graph: Patient 3. A 59-year-old male with respiratory distress and bilateral ground glass opacities on the CT scan. Co-morbidity: Obesity, diabetes mellitus and gout. No new ECG changes were observed during treatment with lidocaine. Blood metHb were within the normal range (0.1-0.4\%). The patient was discharged from the ICU on day 8 and was discharged home on day 20. After 3 months, he is doing well. Right graph: Patient 4. A 51-year-old male with fever, dyspnoea and cough due to COVID-19. The CT scan showed bilateral ground glass opacities. Co-

(moderate ARDS). The KL-6 on day 22 dropped to $458 \mathrm{U} / \mathrm{L}$ (this is only slightly above the normal value of $<450 \mathrm{U} / \mathrm{l}$ ). On day 31 , the CRP was low at $1 \mathrm{mg} / \mathrm{L}$, and the lidocaine plasma concentration was $1.2 \mu \mathrm{g} / \mathrm{ml}$. The muscle relaxants were discontinued. Albumin was $2.3 \mathrm{~g} / \mathrm{dl}$. On day 33, the chest Xray was further improved, and the CRP remained low at 5.5 $\mathrm{mg} / \mathrm{L}$. The patient was awake and could communicate with the nurses. On day 38 , the lidocaine plasma level was 2.3. On day 43, the $\mathrm{PaO}_{2} / \mathrm{FiO}_{2}$ ratio was increased to $214 \mathrm{~mm} \mathrm{Hg}$. According to the Berlin definition of ARDS [404], the patient's ARDS status had changed from moderate to mild. Albumin was $2.8 \mathrm{~g} / \mathrm{dl}$. On day 50 , the patient was weaned from ECMO. On day 51, the patient underwent tracheotomy. Because the clinical condition of the patient was stabilised with a low CRP of $6.3 \mathrm{mg} / \mathrm{L}$ on day 55 , the continuous
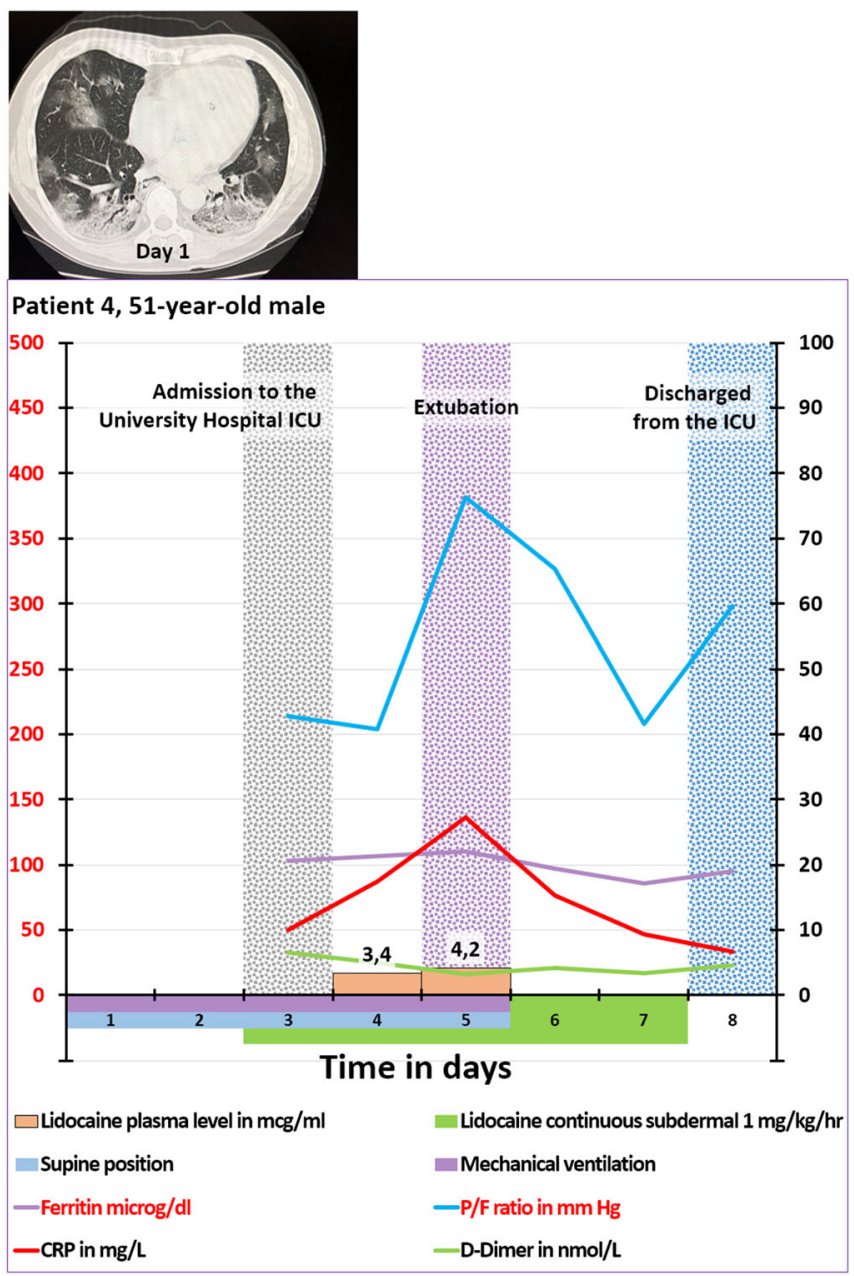

morbidity: none. No new ECG changes were observed during treatment with lidocaine. Blood metHb were within the normal range $(0.1-0.3 \%)$. The patient was discharged from the ICU on day 8 and was disc harged home on day 28. At 3 months, he is doing well and has returned to work. The red-coloured labels of the legends refer to graph plots using the (left) primary $Y$-axis, and the black-coloured labels of the legends refer to graph plots using the (right) secondary $Y$-axis

subdermal lidocaine was discontinued on day 57. On day 69 , he developed pneumothorax requiring pleural drainage. On day 99, he was weaned from the mechanical ventilator and was discharged from the ICU on day 121. No new ECG changes were observed during treatment with lidocaine. Blood methaemoglobin (metHb) were within the normal range $(0.3-0.8 \%)$. CT scan on day 146 showed reduced ground glass opacities in both lungs, some interstitial change in upper and middle fields of the lung and improvement of the pneumothorax. The patient left the hospital on day 187, he went home, and he could walk but needed extra oxygen supply of $2 \mathrm{~L} / \mathrm{min}$. Nine months after admission, the patient is doing well and has returned to work. The patient visited the hospital 3 months after discharge: He only uses oxygen $1 \mathrm{~L} /$ min to go shopping and during physical training (out-patient 

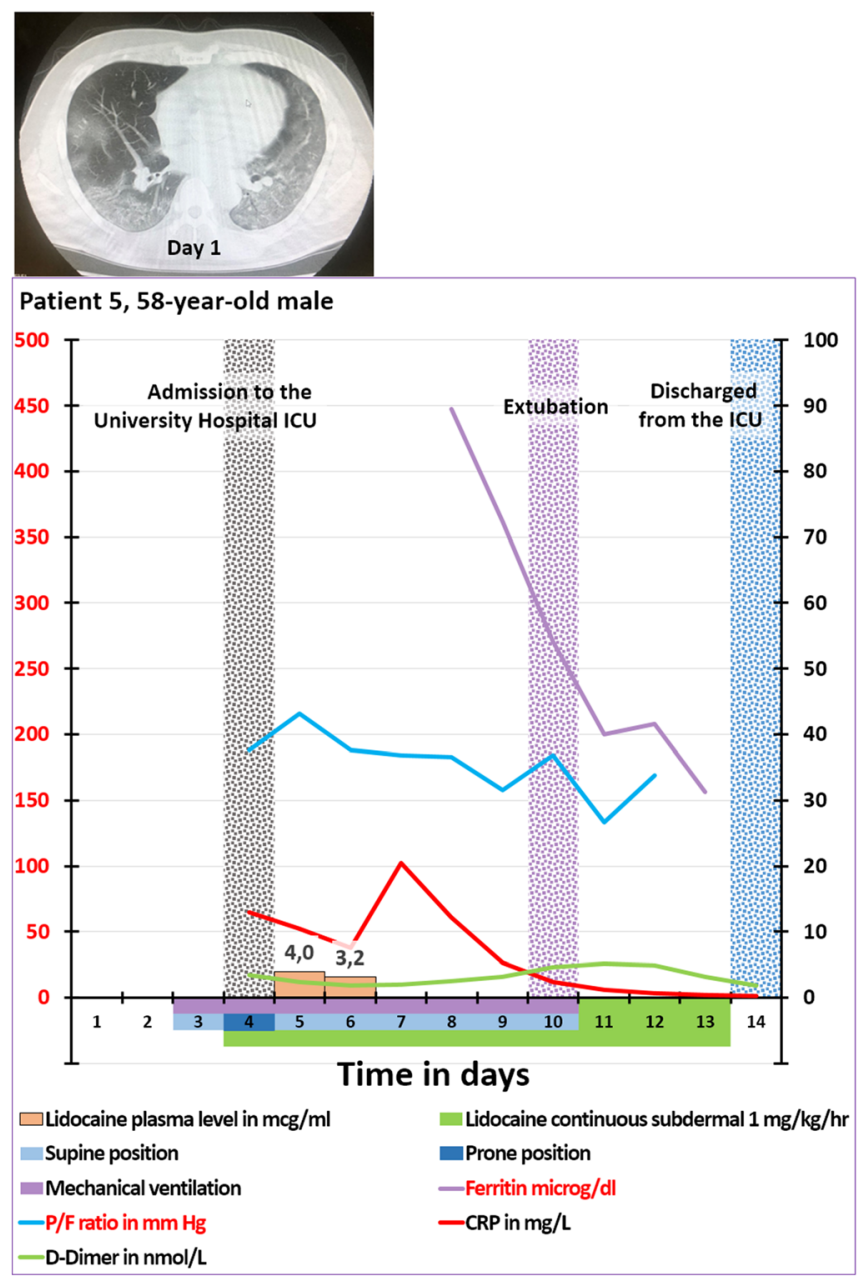

Fig. 10 Left gr aph: P atient 5. A 58 -year-o ld male with fever, dyspnoea and cough due to COVID-19. The CT scan showed bilateral ground glass opacities. Co-morbidity: Fatty liver. No new ECG changes were observed during treatment with lidocaine. Blood metHb were within the normal range $(0.1-0.3 \%)$. On day 14 , the patient was discharged from the ICU. On day 20, the patient was discharged home and is doing well at 3 months after admission. Right graph: Patien ts 6. A 59-year-old male with fever, dyspnoea and cough due to COVID-19. CT scan showed bilateral ground glass opacities. Co-morbidity: Hypertension on

rehabilitation). He talked to the treating intensivist without requiring oxygen and had no shortness of breath or tachypnoea.

The second patient (Fig. 8) is a 68-year-old male $(75 \mathrm{~kg}$, $164 \mathrm{~cm}$ ) with SARS-Cov-2-induced ARDS and positive SARS-Cov-2 PCR test admitted to the university hospital. Co-morbidity is asthma. The CT scan showed bilateral ground glass opacities. Haemodynamically the patient was stable. The patient received tocilizumab on day 8 and favipiravir for 14 days; he did not receive dexamethasone. On day 2 , the respiratory conditions deteriorated, and the $\mathrm{PaO}_{2} / \mathrm{FiO}_{2}$ ratio is $118 \mathrm{~mm} \mathrm{Hg}$ (moderate ARDS according to the Berlin ARDS definition [404]). The patient was intubated and required mechanical ventilation. The initial ventilator settings include pressure control, peak inspiratory pressure $28 \mathrm{~cm}$
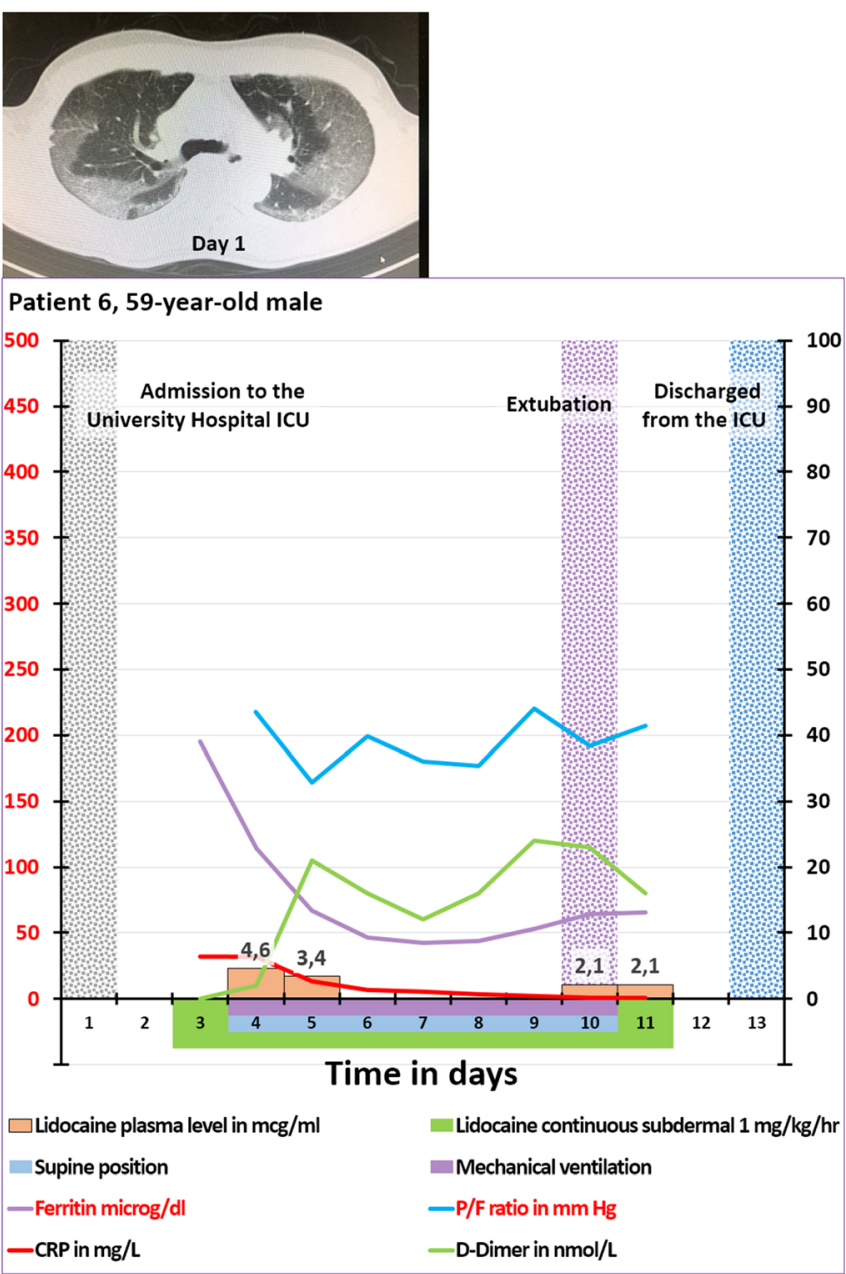

medication. No new ECG changes were observed during treatment with lidocaine. MetHb were within the normal range $(0.1-0.3 \%)$. On day 13 , the patient was discharged from the ICU. He was discharged from the hospital on day 20, and a t 3 months after admission, he is doing well, played golf regularly and has returned to work. The red-coloured labels of the legends refer to graph plots using the (left) primary $Y$-axis, and the black-coloured labels of the legends refer to graph plots using the (right) secondary $Y$-axis

$\mathrm{H}_{2} \mathrm{O}$, PEEP $13 \mathrm{~cm} \mathrm{H}_{2} \mathrm{O}$ and respiratory rate $30 / \mathrm{min}$. CRP was $10.6 \mathrm{mg} / \mathrm{L}$, and $\mathrm{KL}-6$ was $486 \mathrm{U} / \mathrm{ml}$. White blood cell count, platelet count and urine production were normal. The ferritin levels remained $>1000 \mathrm{ng} / \mathrm{ml}(100 \mu \mathrm{g} / \mathrm{dl})$ during the entire ICU stay. Albumin was $2.9 \mathrm{~g} / \mathrm{dl}$. In the following 3 days, the $\mathrm{PaO}_{2} / \mathrm{FiO}_{2}$ ratio improved to around $150 \mathrm{~mm} \mathrm{Hg}$. The $\mathrm{PaO}_{2} / \mathrm{FiO}_{2}$ ratio dropped from 152 on day 5 to $84 \mathrm{~mm} \mathrm{Hg}$ on day 6. CRP was increased to 22.9 , and the KL-6 was increased to $762 \mathrm{U} / \mathrm{ml}$. The patient was put in prone position and given muscle relaxants. Continuous intravenous lidocaine of $0.6 \mathrm{ml} / \mathrm{kg} / \mathrm{h}$ was started. Albumin was $1.8 \mathrm{~g} / \mathrm{dl}$. On day 7 , the $\mathrm{PaO}_{2} / \mathrm{FiO}_{2}$ ratio increased to $128 \mathrm{~mm} \mathrm{Hg}, \mathrm{CRP}$ dropped to $10.3 \mathrm{mg} / \mathrm{mL}$ and the lidocaine plasma concentration was 2.2 $\mu \mathrm{g} / \mathrm{ml}$. From day 3 until discharge from the ICU, D-dimer values were elevated reaching $75 \mathrm{nM} / \mathrm{L}$ on day 14 . On day 
8 , although the $\mathrm{PaO} 2 / \mathrm{FiO} 2$ ratio improved from 84 to $125 \mathrm{~mm}$ $\mathrm{Hg}$, the mechanical ventilatory strategies were exhausted, and the patient was put on ECMO. The KL-6 was increased to 845 $\mathrm{U} / \mathrm{L}$, and lidocaine plasma level was $2.9 \mu \mathrm{g} / \mathrm{ml}$. The $\mathrm{PaO}_{2} /$ $\mathrm{FiO}_{2}$ ratio improved to $238 \mathrm{~mm} \mathrm{Hg}$ on day 9, but on day 10, a sharp drop of the $\mathrm{PaO}_{2} / \mathrm{FiO}_{2}$ ratio to $60 \mathrm{~mm} \mathrm{Hg}$ was observed, and CRP was $2.0 \mathrm{mg} / \mathrm{ml}$. The patient's ARDS status had changed from moderate to severe according to the Berlin ARDS criteria [404]. Lidocaine treatment was switched from continuous intravenous to continuous subdermal (dosage: 1 $\mathrm{mg} / \mathrm{kg} / \mathrm{h}$ ). On day 14 , the lidocaine plasma level was 2.7 $\mu \mathrm{g} / \mathrm{ml}$. KL-6 dropped to $549 \mathrm{U} / \mathrm{l}$. On day 17 , the clinical condition of the patient was improving, and the $\mathrm{PaO}_{2} / \mathrm{FiO}_{2}$ ratio reached $158 \mathrm{~mm} \mathrm{Hg}$. The patient was weaned from ECMO. The $\mathrm{PaO}_{2} / \mathrm{FiO}_{2}$ ratio improved further reaching $291 \mathrm{~mm} \mathrm{Hg}$ on day 21, and the patient's ARDS status has changed from moderate to mild ARDS [404]. On day 22, mechanical ventilation was discontinued, and the patient was extubated. The patient was orientated, and no signs of confusion were detected. CT scan on day 25 showed persistent ground glass opacities in both lungs, some pulmonary effusion (right $>$ left), and no signs of vascular thrombosis. In addition, no signs of deep venous thrombosis were found in the lower extremities. Lidocaine treatment was continued until discharge from the ICU on day 30. No new ECG changes were observed during treatment with lidocaine. Blood metHb were within the normal range $(0.1-0.6 \%)$. The patient was discharged home on day 37 . At 3 months after admission, the patient is doing well.

The third patient (Fig. 9left), a 59-year-old male (109 $\mathrm{kg}, 170 \mathrm{~cm}$ ), was admitted to the university hospital with respiratory distress and bilateral ground glass opacities on the CT scan with a positive SARS-CoV-2 test. Comorbidities include obesity (BMI $37.7 \mathrm{~kg} / \mathrm{m}^{2}$ ), diabetes mellitus and gout. The patient required immediate intubation and mechanical ventilation. The patient received tocilizumab on day 3 and favipiravir for 15 days and did not receive dexamethasone. The initial ventilator settings are pressure control, peak inspiratory pressure $30 \mathrm{~cm} \mathrm{H}_{2} \mathrm{O}$, PEEP $15 \mathrm{~cm} \mathrm{H}_{2} \mathrm{O}$ and respiratory rate $25 / \mathrm{min}$. The $\mathrm{PaO}_{2} / \mathrm{FiO}_{2}$ ratio on admission was $160 \mathrm{~mm} \mathrm{Hg}$ (moderate ARDS according to the Berlin definition [404]), CRP was $39.3 \mathrm{mg} / \mathrm{L}$ and $\mathrm{KL}-6$ was $294 \mathrm{U} / \mathrm{ml}$. White blood cell count was increased $\left(13.10^{-9} / \mathrm{L}\right)$ and platelet count and urine production were normal. Albumin was $2.1 \mathrm{~g} / \mathrm{dl}$. Haemodynamic parameters were stable. On the admission day, continuous subdermal lidocaine was started at 1 $\mathrm{mg} / \mathrm{kg} / \mathrm{h}$. On day 2, the $\mathrm{PaO}_{2} / \mathrm{FiO}_{2}$ ratio improved to $283 \mathrm{~mm} \mathrm{Hg}$, and the patient's ARDS status had changed from moderate to mild ARDS. CRP was $41 \mathrm{mg} / \mathrm{L}$, KL-6 was $268 \mathrm{U} / \mathrm{L}$ and the lidocaine plasma level was 3.7 $\mu \mathrm{g} / \mathrm{ml}$. Albumin was $1.7 \mathrm{~g} / \mathrm{dl}$. On day 4 , the $\mathrm{PaO}_{2} / \mathrm{FiO}_{2}$ ratio was $302 \mathrm{~mm} \mathrm{Hg}$, and the patient's ARDS status had changed from mild ARDS to no ARDS according to the Berlin ARDS criteria. On day 5, the $\mathrm{PaO}_{2} / \mathrm{FiO}_{2}$ ratio was improved further to $328 \mathrm{~mm} \mathrm{Hg}$, and CRP dropped to 16.4 , and the patient was extubated. The patient was orientated, no signs of confusion were detected. The patient was discharged from the ICU on day 8; CRP was 2.3 $\mathrm{mg} / \mathrm{ml}$. Albumin was $2.5 \mathrm{~g} / \mathrm{dl}$. No new ECG changes were observed during treatment with lidocaine. Blood metHb were within the normal range $(0.1-0.4 \%)$. The patient was discharged home on day 20. After 3 months, he is doing well.

The fourth patient (Fig. 9right) is a 51-year-old male (68 $\mathrm{kg}, 175 \mathrm{~cm})$. Ten days before admission, he developed fever and 2 days before admission dyspnoea and coughing. On the day of admission, the PCR SARS-CoV-2 test was positive. The CT scan showed bilateral ground glass opacities. Comorbidity is none. The patient was intubated and put on mechanical ventilation on admission. The patient received favipiravir for 14 days; he did not receive dexamethasone. On day 3 , he was transferred to the university hospital because of deterioration of pulmonary condition. The initial ventilator settings include pressure control, peak inspiratory pressure $24 \mathrm{~cm} \mathrm{H}_{2} \mathrm{O}$, PEEP $12 \mathrm{~cm} \mathrm{H}_{2} \mathrm{O}$ and respiratory rate $15 / \mathrm{min}$. The haemodynamic conditions were stable. White blood cell count and platelet count were normal. Albumin was $2.6 \mathrm{~g} / \mathrm{dl}$. Continuous subdermal lidocaine was started immediately. On day 3, the $\mathrm{PaO}_{2} / \mathrm{FiO}_{2}$ ratio was 214 (moderate ARDS according to the Berlin definition [404]). KL-6 was $177 \mathrm{U} / \mathrm{L}$, and CRP was $17.4 \mathrm{mg} / \mathrm{L}$. On day 5 , the $\mathrm{PaO}_{2} / \mathrm{FiO}_{2}$ ratio was increased to 382 (the patient's ARDS status had changed from mild ARDS to no ARDS), and lidocaine plasma concentration was $5.2 \mu \mathrm{g} / \mathrm{ml}$. CRP was $27.3 \mathrm{mg} / \mathrm{L}$. Lidocaine plasma levels on day 3 and 4 were 3.4 and $4.2 \mu \mathrm{g} / \mathrm{ml}$, respectively. KL-6 was $163 \mathrm{U} / \mathrm{L}$. The patient was extubated. The patient was orientated, and no signs of confusion were detected. The patient was discharged from the ICU on day 8, and the CRP was $9.3 \mathrm{mg} / \mathrm{L}$. No new ECG changes were observed during treatment with lidocaine. Blood metHb were within the normal range $(0.1-0.3 \%)$. He was discharged home on day 28 . At 3 months, he is doing well and has returned to work.

The fifth patient (Fig. 10left) is a 58-year-old male $(80 \mathrm{~kg}$, $175 \mathrm{~cm})$. Nine days before admission, he developed a sore throat. A day later, he developed fever. Two days before admission, he started coughing and was dyspnoeic. On the day of admission, the PCR SARS-Cov-2 test was positive. Comorbidity includes fatty liver. The CT scan showed bilateral ground glass opacities. The patient was initially admitted to the hospital ward. The patient received tocilizumab on day 7 and favipiravir for 10 days; dexamethasone was not prescribed. On day 3 , the patient deteriorated and had to be intubated and put on mechanical ventilation. On day 4, the patient was transferred to the university hospital due to deterioration of the pulmonary condition. The initial ventilator 
settings include pressure control, peak inspiratory pressure $27 \mathrm{~cm} \mathrm{H} 2 \mathrm{O}$, PEEP $12 \mathrm{~cm} \mathrm{H} 2 \mathrm{O}$ and respiratory rate 25/min. $\mathrm{PaO}_{2} / \mathrm{FiO}_{2}$ ratio was 188 (moderate ARDS according to the Berlin definition). Haemodynamic parameters were stable, and CRP was $12.9 \mathrm{mg} / \mathrm{ml}$. White blood cell count was increased $\left(14.4 .10^{9} / \mathrm{L}\right)$, but platelet count was normal. KL-6 was $330 \mathrm{U} / \mathrm{L}$. Continuous subdermal lidocaine was started at $1 \mathrm{mg} / \mathrm{kg} / \mathrm{h}$ at arrival at the ICU of the university hospital. Albumin was $2.8 \mathrm{~g} / \mathrm{dl}$. On day 5 , the $\mathrm{PaO}_{2} / \mathrm{FiO}_{2}$ ratio was unchanged, CRP was $10.4 \mathrm{mg} / \mathrm{L}$ and the lidocaine plasma level was $4 \mu \mathrm{g} / \mathrm{ml}$. On day 6 , the lidocaine plasma level was $3.2 \mu \mathrm{g} / \mathrm{ml}$. KL-6 remained stable at $400 \mathrm{U} / \mathrm{L}$. Albumin was 2.3 $\mathrm{g} / \mathrm{dl}$. On day 10 , the respiratory insufficiency had cleared; although the $\mathrm{PaO} 2 / \mathrm{FiO} 2$ ratio remained 184 , the CRP dropped to $2.4 \mathrm{mg} / \mathrm{L}$, and KL-6 was $322 \mathrm{U} / \mathrm{L}$. The patient was extubated, and he was orientated; no signs of confusion were detected. On day 14, the patient was discharged from the ICU. No new ECG changes were observed during treatment with lidocaine. Blood metHb were within the normal range $(0.1-$ $0.3 \%$ ). On day 20 , the patient was discharged home and is doing well at 3 months after admission.

The sixth patient (Fig. 10right) is a 59-year-old male $(65 \mathrm{~kg}, 175 \mathrm{~cm})$ with fever, dyspnoea and cough due to COVID-19. CT scan showed bilateral ground glass opacities. Co-morbidity includes hypertension on medication. The patient was admitted to the general ward. KL-6 233 $\mathrm{U} / \mathrm{L}$, white blood cell count and platelet count were normal. Albumin was $3.6 \mathrm{~g} / \mathrm{dl}$. On day 3, there is a deterioration of the respiratory function necessitating a transfer to the ICU and mechanical ventilation. Tocilizumab was given on day 4. The patient received favipiravir for 11 days, and the patient did not receive dexamethasone. The initial ventilator settings include pressure control, peak inspiratory pressure $22 \mathrm{~cm} \mathrm{H}_{2} \mathrm{O}$, PEEP $10 \mathrm{~cm} \mathrm{H}_{2} \mathrm{O}$ and respiratory rate $20 / \mathrm{min}$. Continuous subdermal lidocaine of $1 \mathrm{mg} / \mathrm{kg} / \mathrm{h}$ was initiated after admission to the ICU. Haemodynamic parameters were stable. CRP was 6.3 $\mathrm{mg} / \mathrm{L}$, and KL-6 was $263 \mathrm{U} / \mathrm{L}$. On day 4, a progressive respiratory failure occurred requiring intubation and mechanical ventilation. $\mathrm{PaO}_{2} / \mathrm{FiO}_{2}$ ratio was $218 \mathrm{~mm} \mathrm{Hg}$; the haemodynamic parameters remained stable. CRP was $6.3 \mathrm{mg} / \mathrm{L}$, and the white blood count and platelet count were normal. Lidocaine plasma level was 4.6 $\mu \mathrm{g} / \mathrm{ml}$. On day 5, the $\mathrm{PaO}_{2} / \mathrm{FiO}_{2}$ ratio dropped further to $164 \mathrm{~mm} \mathrm{Hg}$. Lidocaine plasma level was $3.4 \mu \mathrm{g} / \mathrm{ml}$. Albumin was $3.2 \mathrm{~g} / \mathrm{dl}$. On day 9 , the clinical condition of the patient improved. The ventilator settings could be decreased, the $\mathrm{PaO}_{2} / \mathrm{FiO}_{2}$ ratio remained $207 \mathrm{~mm} \mathrm{Hg}$ during the weaning period, and CRP was $0.7 \mathrm{mg} / \mathrm{L}$. On day 10 , the patient was extubated, he was orientated, and no signs of confusion were detected. On day 13, the patient was discharged from the ICU. No new ECG changes were observed during treatment with lidocaine.
Blood metHb were within the normal range $(0.1-0.3 \%)$. He was discharged from the hospital on day 20 , and at 3 months after admission, he is doing well, played golf regularly and has returned to work.

\section{Additional 14 patients with COVID-19-induced ARDS}

From July 2020 until beginning of December 2020, 14 additional critically ill patients with COVID-19-induced ARDS requiring mechanical ventilation were treated in the ICU of the Showa University with continuous subdermal lidocaine infusion $(1 \mathrm{mg} / \mathrm{kg} / \mathrm{h})$ plus intravenous or oral dexamethasone $(6 \mathrm{mg} /$ day $)$ as reported earlier [35]. Of these 20 patients, 19 survived, but an 87-year-old female patient died of invasive aspergillosis. No other patient developed secondary coinfections (unpublished data, personal communication by $\mathrm{AS}$ and TK).

\section{Discussion of the clinical cases}

After completing the novel definition of hyperinflammation, we developed a new approach to target the lymphatic system with continuous subdermal administration of lidocaine. This is meant to increase the anti-hyperinflammatory effect of lidocaine while avoiding toxic plasma levels. We described the treatment of six critically ill patients with COVID-19 with lidocaine. Two patients required mechanical ventilation and ECMO, and four patients were treated with mechanical ventilation. As mentioned under the heading "Introduction", the case fatality rates of patients requiring mechanical ventilation and/or ECMO are alarmingly high $[1,2]$. Patient 1 and patient 2 were older than 60 years. Additionally, patient 1 had COPD and had smoked 60 cigarettes per day for more than 40 years. Patient 3 suffered from obesity and diabetes mellitus. These are serious prognostic factors for bad outcome COVID-19 [406, 407]. Patient 1 and patient 2 were initially treated with continuous intravenous lidocaine through a central venous line. In both patients, the pulmonary conditions deteriorated after the initiation of intravenous lidocaine: Patient 1 who was already on ECMO showed progressive pulmonary deterioration on the chest X-rays, and patient 2 deteriorated further necessitating the initiation of ECMO therapy. Remarkably, the pulmonary conditions of both patients improved within $48 \mathrm{~h}$ after the switch from intravenous to subdermal continuous lidocaine. The lidocaine plasma levels remained around 5 $\mu \mathrm{g} / \mathrm{ml}$. To our knowledge, these six cases represent the first observations of the promising treatment of critically ill COVID-19 patients with lidocaine targeting P2X7Rs of the immune cells in the lymphatics. All patients recovered completely from their illness. None of the patients showed the feared side effect of cardiac arrhythmia and methaemoglobinaemia during lidocaine therapy. Our findings suggest that continuous subdermal lidocaine infusion at the 
rate of $1 \mathrm{mg} / \mathrm{kg} / \mathrm{h}$ has the potential to mitigate hyperinflammation and ARDS in critically ill COVID-19-patients. Obviously, although all six patients appeared to respond positively to the treatment and no severe adverse effects were observed, no final conclusions can be made on the efficacy of lidocaine in critically ill COVID-19 patients.

Researchers from Lima, Peru, reported the treatment of 28 (three mild, 21 moderate and four severe) COVID-19 patients with $0.5 \%$ lidocaine HCL solution with an intravenous dose of $1 \mathrm{mg} / \mathrm{kg}$ once a day for 2 days and $2 \%$ lidocaine HCL solution with a subcutaneous dose of $1 \mathrm{mg} / \mathrm{kg}$ once a day for 2 days [408]. The authors aimed at the improvement of pain, cough, respiratory rate and oxygen saturation. They found improvement in most patients. In severe cases, this treatment did not improve the oxygen saturation. As expected, treatment with a low daily dose of lidocaine once per day for a total treatment duration of 2 days could not adequately inhibit the P2X7Rinduced hyperinflammation in COVID-19.

Recently, a group of researchers from Strasbourg, France, announced a study entitled: "Impact of intravenous lidocaine on clinical outcomes of patients with ARDS during COVID19 pandemia (LidoCovid): A structured summary of a study protocol for a randomised controlled trial" (ClinicalTrials.gov Identifier: NCT04609865) [409].

Lately, an extraordinary treatment of COVID-19 ARDS was reported [410]. The authors performed lung transplantations in three critically ill COVID-19 ARDS patients: a 28-year-old female, a 62-year-old male and a 43-year-old male. The first patient underwent lung transplantation after weeks on veno-venous ECMO support with elevated pulmonary arterial pressures and severe secondary Serratia marcescens pneumonia. The second patient underwent lung transplantation after 100 days on veno-venous ECMO support complicated by Pseudomonas aeruginosa pneumonia, haemothorax and empyema, while the third patient after 90 days on the mechanical ventilator. This patient suffered from many complications: asystolic cardiac arrest, heparin-induced thrombocytopenia, a left frontal lobe infarct of the cerebral cortex, Serratia marcescens-mediated pneumonia with bacteraemia, acute kidney injury, a left haemothorax requiring thoracotomy and lung decortication, a right pneumothorax requiring tube thoracostomy, hypernatremia associated with seizures and malnutrition. Before lung transplantation, the patient developed increasing clinical signs of pulmonary fibrosis and severe pulmonary hypertension. The first two patients are reported to have achieved independence in daily life activities several months after lung transplantation. Three months after lung transplantation, the third patient made improvements in the neurocognitive status and muscular strength at an inpatient rehabilitation centre.
Far less drastic is our proposed treatment of hyperinflammation in COVID-19-induced ARDS with lidocaine, an old drug that is readily available to hospitals all over the world at a low cost. In November 1948, Xylocaine was approved by the Food and Drug Administration (FDA) in the USA [411]. Lidocaine is used as a local anaesthetic [411], treatment of chronic neuropathic pain [412] but also for the prophylaxis or treatment of ventricular arrhythmia [328, 329]. Recently, intravenous lidocaine has been administered as general anaesthetic replacing opioids in the perioperative settings [413]. Potentially, lidocaine, as a P2X7R antagonist, can abrogate hyperinflammation, can restore the capacity of the immune system to combat secondary co-infections and can improve the clinical condition in critically ill COVID-19 patients. Despite several in vitro [326, 327, 414, 415], animal studies [319, 416-420] and patient cohorts [408, 421] on the anti-inflammatory properties of lidocaine, completed clinical trials which deliver a proof of concept (i.e. a randomised controlled trial) have not yet been performed. We postulate that because the maximal tolerable plasma concentration of lidocaine is much lower than the required extracellular concentration to effectively inhibit P2X7Rs, intravenous systemic administration of lidocaine simply cannot not be used to effectively treat hyperinflammation. This is a plausible reason why 5 years after the discovery of lidocaine as a P2X7R inhibitor (published in 2015) [74] the drug is still not used as an antihyperinflammatory treatment in clinical practice.

\section{Concluding remarks}

As stated in the introduction, therapeutic measures that can immediately attenuate the course of SARS-CoV-2-related lung damage are promptly needed on a global scale. In contrast to the investigational $\mathrm{P} 2 \mathrm{X} 7 \mathrm{R}$ antagonists described above, continuous subdermal infusion of $2 \%$ lidocaine solution to primarily deposit lidocaine into the lymphatics is readily available and can be used in the daily practice immediately and, in principle, even outside the ICU and is very well affordable. Therefore, this therapy deserves to be investigated in larger placebo controlled randomised clinical studies with COVID-19 patients.

\section{Future development}

However, our experience with subdermal administration of lidocaine in the ICU made clear that this method may not be routinely suitable outside hospital settings. Needless to say that high complexity and high-cost treatments (requiring highly skilled nurses and infusion pump equipment) are inaccessible to low-income COVID-19 patients in developing 
countries. Also, as the severity and case fatality rate of COVID-19 increase with age [406], the case fatality rate in elderly patients in nursing homes is strikingly high, and many residents have poor access to medical care [422]. This encouraged us to explore alternative uncomplicated methods of lidocaine administration accessible to everyone, particularly elderly COVID-19 patients and COVID-19 patients in developing countries.

Recently, researchers stated in their article on targeting the P2X7R in COVID-19 that the P2X7R antagonists for human use are available only in oral form and that this might be an inefficient route of drug delivery [298]. We found a solution to this problem. Permeability of the skin and mucous membrane to water, drugs, etc. is said to be dependent on the site of the administration [423, 424]. For example, the permeability constant of the floor of the mouth (sublingual mucosa), lateral border of the tongue and buccal mucosa for tritium-labelled water is 22,17 and 13 times as high as human skin, respectively [423]. We argue that this also applies to lidocaine. As mentioned above, the endothelium of the mucosal capillaries of the mouth and the gastrointestinal tract belong to the structural type "fenestrated endothelium" allowing molecules to pass from the submucosal tissue into the capillaries [383]. Lidocaine hydrochloride is highly soluble in water (solubility of $680 \mathrm{mg} / \mathrm{ml}$ in water) [425] and therefore will mainly be absorbed by the submucosal capillary [426] and the inductive sites of MALT [398, 399]. In contrast, the highly lipophilic lidocaine base (solubility of $4 \mathrm{mg} / \mathrm{ml}$ in water, $760 \mathrm{mg} / \mathrm{ml}$ in $95 \%$ ethanol and $790 \mathrm{mg} / \mathrm{ml}$ in chloroform) [425] is preferably absorbed by the local initial lymphatics in the submucosal tissue [426, 427]. In addition, the lymphatic drainage of the floor of the mouth is extensive, involving many lymph nodes [428-431].

We estimate that with a sublingual administration of lipophilic lidocaine base (Fig. 1), we may reach the $\mathrm{IC}_{50}$ of the P2X7Rs in the draining lymph nodes to control systemic hyperinflammation and avoid toxic lidocaine plasma levels (Figs. 4 and 6). Obviously, such solution may also apply to other P2X7R antagonists. We stress that sublingual and buccal administration of lipophilic lidocaine is different from oral administration of lidocaine. Oral administration of lidocaine is aimed at the resorption of the drug in the gastrointestinal tract (Fig.6).

There are other methods of targeting the immune cells in the lymphatics, i.e. transdermal administration of lipophilic P2X7R antagonist with skin penetration enhancers (i.e. alpha-terpineol [432], ethanol [433] and lipid based nanoformulations [434]), intravenous administration of a P2X7R antagonist using nano-sized drug delivery systems [435], liposomes or polymer micelles [436] and oral administration of a P2X7R antagonist using delivery systems for intestinal lymphatic drug transport such as chylomicrons [437].
Acknowledgements We dedicate this report to the memory of Professor Geoffrey Burnstock, the discoverer of purinergic signalling. This report makes clear that purinergic signalling is indispensable to see through the complicated pathophysiology of hyperinflammation in COVID-19.

We would like to thank Coosje van der Pol, PhD, for her valuable and constructive editing suggestions during the writing of this research work.

Author contribution Conception, design and data handling: DH, AS, CvK, EPK and TK

Substantial contributions to the conception and design of the manuscript: DH, AS, CvK and EPK

Acquisition, analysis or interpretation of data for the manuscript: DH, AS, EPK and TK

Drafting and revising the manuscript: DH, AS, CvK, PJvdS, EPK and TK

Drafting the manuscript: DH, AS, CvK, PJvdS, EPK and TK

Revising the manuscript critically for intellectual content: DH, AS, CvK, PJvdS, EPK and TK

Final approval of the version to be published: DH, AS, CvK, PJvdS, EPK and TK

Agreement to be accountable for all aspects of the work in ensuring that questions related to the accuracy or integrity of any part of the work are appropriately investigated and resolved: DH, AS, CvK, PJvdS, EPK and TK

Data Availability The datasets generated during and/or analysed during the current study are not publicly available due to privacy reasons but are available from the corresponding author on reasonable request.

Code availability Not applicable.

\section{Declarations}

Ethics approval, consent to participate and consent for publication The Medical Ethical Committee of the Showa University, School of Medicine, Tokyo, approved the collection, analysis and publication of patients on mechanical ventilation admitted to the ICU (protocol number 3313).

Conflicts of interest DH: The author declares to have filed patent applications that are based on the content of the paper.

AS: none.

CvK: none.

PJvdS: none.

EPK: none.

TK: none.

Open Access This article is licensed under a Creative Commons Attribution 4.0 International License, which permits use, sharing, adaptation, distribution and reproduction in any medium or format, as long as you give appropriate credit to the original author(s) and the source, provide a link to the Creative Commons licence, and indicate if changes were made. The images or other third party material in this article are included in the article's Creative Commons licence, unless indicated otherwise in a credit line to the material. If material is not included in the article's Creative Commons licence and your intended use is not permitted by statutory regulation or exceeds the permitted use, you will need to obtain permission directly from the copyright holder. To view a copy of this licence, visit http://creativecommons.org/licenses/by/4.0/. 


\section{References}

1. Quah P, Li A, Phua J (2020) Mortality rates of patients with COVID-19 in the intensive care unit: a systematic review of the emerging literature. Crit Care 24(1):285. https://doi.org/10.1186/ s13054-020-03006-1

2. Barbaro RP, MacLaren G, Boonstra PS, Iwashyna TJ, Slutsky AS, Fan E, Bartlett RH, Tonna JE, Hyslop R, Fanning JJ, Rycus PT, Hyer SJ, Anders MM, Agerstrand CL, Hryniewicz K, Diaz R, Lorusso R, Combes A, Brodie D (2020) Extracorporeal membrane oxygenation support in COVID-19: an international cohort study of the Extracorporeal Life Support Organization registry. Lancet 396(10257):1071-1078. https://doi.org/10.1016/s01406736(20)32008-0

3. Manson JJ, Crooks C, Naja M, Ledlie A, Goulden B, Liddle T, Khan E, Mehta P, Martin-Gutierrez L, Waddington KE, Robinson GA, Ribeiro Santos L, McLoughlin E, Snell A, Adeney C, Schim van der Loeff I, Baker KF, Duncan CJA, Hanrath AT et al (2020)COVID-19-associated hyperinflammation and escalation of patient care: a retrospective longitudinal cohort study. Lancet Rheumatol 2(10):e594-e602. https://doi.org/10.1016/s26659913(20)30275-7

4. Gustine JN, Jones D (2021) Immunopathology of hyperinflammation in COVID-19. Am J Pathol 191(1):4-17. https://doi.org/10.1016/j.ajpath.2020.08.009

5. Afrin LB, Weinstock LB, Molderings GJ (2020)Covid-19 hyperinflammation and post-Covid-19 illness may be rooted in mast cell activation syndrome. Int J Infect Dis 100:327-332. https://doi.org/10.1016/j.ijid.2020.09.016

6. Fajgenbaum DC, June CH (2020) Cytokine Storm. N Engl J Med 383(23):2255-2273. https://doi.org/10.1056/NEJMra2026131

7. Webb BJ, Peltan ID, Jensen P, Hoda D, Hunter B, Silver A, Starr N, Buckel W, Grisel N, Hummel E, Snow G, Morris D, Stenehjem E, Srivastava R, Brown SM (2020) Clinical criteria for COVID19-associated hyperinflammatory syndrome: a cohort study. Lancet Rheumatol 2(12):e754-e763. https://doi.org/10.1016/ s2665-9913(20)30343-x

8. Cardone M, Yano M, Rosenberg AS, Puig M (2020) Lessons learned to date on COVID-19 hyperinflammatory syndrome: considerations for interventions to mitigate SARS-CoV-2 viral infection and detrimental hyperinflammation. Front Immunol 11:1131. https://doi.org/10.3389/fimmu.2020.01131

9. Bozzi G, Mangioni D, Minoia F, Aliberti S, Grasselli G, Barbetta L, Castelli V, Palomba E, Alagna L, Lombardi A, Ungaro R, Agostoni C, Baldini M, Blasi F, Cesari M, Costantino G, Fracanzani AL, Montano N, Monzani V et al (2021) Anakinra combined with methylprednisolone in patients with severe COVID-19 pneumonia and hyperinflammation: an observational cohort study. J Allergy Clin Immunol 147(2):561-566.e564. https://doi.org/10.1016/ j.jaci.2020.11.006

10. Landewé RBM, Ramiro S, Mostard RLM (2021)COVID19-induced hyperinflammation, immunosuppression, recovery and survival: how causal inference may help draw robust conclusions. RMD Open 7(1). https://doi.org/10.1136/ rmdopen-2021-001638

11. Anka AU, Tahir MI, Abubakar SD, Alsabbagh M, Zian Z, Hamedifar H, Sabzevari A, Azizi G (2021) Coronavirus disease 2019 (COVID-19): an overview of the immunopathology, serological diagnosis and management. Scand J Immunol 93(4): e12998. https://doi.org/10.1111/sji.12998

12. Mehta P, McAuley DF, Brown M, Sanchez E, Tattersall RS, Manson JJ (2020) COVID-19: consider cytokine storm syndromes and immunosuppression. Lancet. https://doi.org/10. 1016/s0140-6736(20)30628-0
13. Freeman TL, Swartz TH (2020) Targeting the NLRP3 Inflammasome in severe COVID-19. Front Immunol 11:1518. https://doi.org/10.3389/fimmu.2020.01518

14. De Luca G, Cavalli G, Campochiaro C, Della-Torre E, Angelillo P, Tomelleri A, Boffini N, Tentori S, Mette F, Farina N, RovereQuerini P, Ruggeri A, D'Aliberti T, Scarpellini P, Landoni G, De Cobelli F, Paolini JF, Zangrillo A, Tresoldi M et al (2020)GMCSF blockade with mavrilimumab in severe COVID-19 pneumonia and systemic hyperinflammation: a single-centre, prospective cohort study. Lancet Rheumatol 2(8):e465-e473. https://doi.org/ 10.1016/s2665-9913(20)30170-3

15. Wang L, He W, Yu X, Hu D, Bao M, Liu H, Zhou J, Jiang H (2020) Coronavirus disease 2019 in elderly patients: Characteristics and prognostic factors based on 4-week follow-up. J Inf Secur. https://doi.org/10.1016/j.jinf.2020.03. 019

16. Lv Z, Cheng S, Le J, Huang J, Feng L, Zhang B, Li Y (2020) Clinical characteristics and co-infections of 354 hospitalized patients with COVID-19 in Wuhan, China: a retrospective cohort study. Microbes Infect 22(4-5):195-199. https://doi.org/10.1016/ j.micinf.2020.05.007

17. Kooistra EJ, Waalders NJB, Grondman I, Janssen NAF, de Nooijer AH, Netea MG, van de Veerdonk FL, Ewalds E, van der Hoeven JG, Kox M, Pickkers P (2020) Anakinra treatment in critically ill COVID-19 patients: a prospective cohort study. Crit Care 24(1):688. https://doi.org/10.1186/s13054-020-03364$\mathrm{w}$

18. Xu X, Han M, Li T, Sun W, Wang D, Fu B, Zhou Y, Zheng X, Yang Y, Li X, Zhang X, Pan A, Wei H (2020) Effective treatment of severe COVID-19 patients with tocilizumab. Proc Natl Acad Sci U S A 117(20):10970-10975. https://doi.org/10.1073/pnas. 2005615117

19. Perrone F, Piccirillo MC, Ascierto PA, Salvarani C, Parrella R, Marata AM, Popoli P, Ferraris L, Marrocco-Trischitta MM, Ripamonti D, Binda F, Bonfanti P, Squillace N, Castelli F, Muiesan ML, Lichtner M, Calzetti C, Salerno ND, Atripaldi L et al (2020) Tocilizumab for patients with COVID-19 pneumonia. The single-arm TOCIVID-19 prospective trial. J Transl Med 18(1):405. https://doi.org/10.1186/s12967-020-02573-9

20. Luis BM, Miguel MB, Pedro DL, David IP, Itziar A, Ana GH, Enrique IJ, María LV, Noelia TF, Julio César BB, Marta UI, Rodrigo SL, María CB, Andrés LM, Javier MI, Juan Pablo GM, Gerardo HF, Carolina NF, Jorge BL et al (2021) Benefits of early aggressive immunomodulatory therapy (tocilizumab and methylprednisolone) in COVID-19: single center cohort study of 685 patients. J Transl Autoimmun 4:100086. https://doi.org/10.1016/ j.jtauto.2021.100086

21. Gokhale Y, Mehta R, Kulkarni U, Karnik N, Gokhale S, Sundar U, Chavan S, Kor A, Thakur S, Trivedi T, Kumar N, Baveja S, Wadal A, Kolte S, Deolankar A, Pednekar S, Kalekar L, Padiyar $\mathrm{R}$, Londhe $\mathrm{C}$ et al (2021) Tocilizumab improves survival in severe COVID-19 pneumonia with persistent hypoxia: a retrospective cohort study with follow-up from Mumbai, India. BMC Infect Dis 21(1):241. https://doi.org/10.1186/s12879-021-05912-3

22. Aomar-Millán IF, Salvatierra J, Torres-Parejo Ú, Faro-Miguez N, Callejas-Rubio JL, Ceballos-Torres Á, Cruces-Moreno MT, Gómez-Jiménez FJ, Hernández-Quero J, Anguita-Santos F (2021) Anakinra after treatment with corticosteroids alone or with tocilizumab in patients with severe COVID-19 pneumonia and moderate hyperinflammation. A retrospective cohort study. Intern Emerg Med 16(4):843-852. https://doi.org/10.1007/ s11739-020-02600-Z

23. Cavalli G, Larcher A, Tomelleri A, Campochiaro C, Della-Torre E, De Luca G, Farina N, Boffini N, Ruggeri A, Poli A, Scarpellini P, Rovere-Querini P, Tresoldi M, Salonia A, Montorsi F, Landoni G, Castagna A, Ciceri F, Zangrillo A, Dagna L (2021)Interleukin- 
1 and interleukin-6 inhibition compared with standard management in patients with COVID-19 and hyperinflammation: a cohort study. Lancet Rheumatol 3(4):e253-e261. https://doi.org/10. 1016/s2665-9913(21)00012-6

24. Gordon AC, Mouncey PR, Al-Beidh F, Rowan KM, Nichol AD, Arabi YM, Annane D, Beane A, van Bentum-Puijk W, Berry LR, Bhimani Z, Bonten MJM, Bradbury CA, Brunkhorst FM, Buzgau A, Cheng AC, Detry MA, Duffy EJ, Estcourt LJ et al (2021)Interleukin-6 receptor antagonists in critically ill patients with Covid-19. N Engl J Med 384(16):1491-1502. https://doi. org/10.1056/NEJMoa2100433

25. The CORIMUNO-19 Collaborative group (2021) Effect of anakinra versus usual care in adults in hospital with COVID-19 and mild-to-moderate pneumonia (CORIMUNO-ANA-1): a randomised controlled trial. Lancet Respir Med 9(3):295-304. https://doi.org/10.1016/s2213-2600(20)30556-7

26. Hermine O, Mariette X, Tharaux PL, Resche-Rigon M, Porcher R, Ravaud P (2021) Effect of tocilizumab vs usual care in adults hospitalized with COVID-19 and moderate or severe pneumonia: a randomized clinical trial. JAMA Intern Med 181(1):32-40. https://doi.org/10.1001/jamainternmed.2020.6820

27. Ramiro S, Mostard RLM, Magro-Checa C, van Dongen CMP, Dormans T, Buijs J, Gronenschild M, de Kruif MD, van Haren EHJ, van Kraaij T, Leers MPG, Peeters R, Wong DR, Landewé RBM (2020) Historically controlled comparison of glucocorticoids with or without tocilizumab versus supportive care only in patients with COVID-19-associated cytokine storm syndrome: results of the CHIC study. Ann Rheum Dis 79(9):1143-1151. https://doi.org/10.1136/annrheumdis-2020-218479

28. Rosas IO, Bräu N, Waters M, Go RC, Hunter BD, Bhagani S, Skiest D, Aziz MS, Cooper N, Douglas IS, Savic S, Youngstein T, Del Sorbo L, Cubillo Gracian A, De La Zerda DJ, Ustianowski A, Bao M, Dimonaco S, Graham E et al (2021) Tocilizumab in hospitalized patients with severe Covid-19 pneumonia. N Engl J Med 384(16):1503-1516. https://doi.org/10.1056/ NEJMoa2028700

29. Salama C, Han J, Yau L, Reiss WG, Kramer B, Neidhart JD, Criner GJ, Kaplan-Lewis E, Baden R, Pandit L, Cameron ML, Garcia-Diaz J, Chávez V, Mekebeb-Reuter M, Lima de Menezes F, Shah R, González-Lara MF, Assman B, Freedman J, Mohan SV (2021) Tocilizumab in patients hospitalized with Covid-19 pneumonia. N Engl J Med 384(1):20-30. https://doi.org/10. 1056/NEJMoa2030340

30. Salvarani C, Dolci G, Massari M, Merlo DF, Cavuto S, Savoldi L, Bruzzi $\mathrm{P}$, Boni $\mathrm{F}$, Braglia L, Turrà $\mathrm{C}$, Ballerini PF, Sciascia R, Zammarchi L, Para O, Scotton PG, Inojosa WO, Ravagnani V, Salerno ND, Sainaghi PP et al (2021) Effect of tocilizumab vs standard care on clinical worsening in patients hospitalized with COVID-19 pneumonia: a randomized clinical trial. JAMA Intern Med 181(1):24-31. https://doi.org/10.1001/jamainternmed.2020. 6615

31. Soin AS, Kumar K, Choudhary NS, Sharma P, Mehta Y, Kataria S, Govil D, Deswal V, Chaudhry D, Singh PK, Gupta A, Agarwal V, Kumar S, Sangle SA, Chawla R, Narreddy S, Pandit R, Mishra V, Goel M, Ramanan AV (2021) Tocilizumab plus standard care versus standard care in patients in India with moderate to severe COVID-19-associated cytokine release syndrome (COVINTOC): an open-label, multicentre, randomised, controlled, phase 3 trial. Lancet Respir Med. https://doi.org/10.1016/s2213-2600(21) 00081-3

32. Stone JH, Frigault MJ, Serling-Boyd NJ, Fernandes AD, Harvey L, Foulkes AS, Horick NK, Healy BC, Shah R, Bensaci AM, Woolley AE, Nikiforow S, Lin N, Sagar M, Schrager H, Huckins DS, Axelrod M, Pincus MD, Fleisher J et al (2020) Efficacy of tocilizumab in patients hospitalized with Covid-19. N Engl J Med. https://doi.org/10.1056/NEJMoa2028836
33. Huang E, Jordan SC (2020) Tocilizumab for Covid-19 - the ongoing search for effective therapies. N Engl J Med 383(24):23872388. https://doi.org/10.1056/NEJMe2032071

34. Beigel JH, Tomashek KM, Dodd LE, Mehta AK, Zingman BS, Kalil AC, Hohmann E, Chu HY, Luetkemeyer A, Kline S, Lopez de Castilla D, Finberg RW, Dierberg K, Tapson V, Hsieh L, Patterson TF, Paredes R, Sweeney DA, Short WR et al (2020) Remdesivir for the treatment of Covid-19 - final report. N Engl J Med 383(19):1813-1826. https://doi.org/10.1056/ NEJMoa2007764

35. Horby P, Lim WS, Emberson JR, Mafham M, Bell JL, Linsell L, Staplin N, Brightling C, Ustianowski A, Elmahi E, Prudon B, Green C, Felton T, Chadwick D, Rege K, Fegan C, Chappell LC, Faust SN, Jaki T et al (2021) Dexamethasone in hospitalized patients with Covid-19. N Engl J Med 384(8):693-704. https:// doi.org/10.1056/NEJMoa2021436

36. Kim PS, Read SW, Fauci AS (2020) Therapy for early COVID19: a critical need. JAMA 324(21):2149-2150. https://doi.org/10. 1001/jama.2020.22813

37. Cain DW, Cidlowski JA (2017) Immune regulation by glucocorticoids. Nat Rev Immunol 17(4):233-247. https://doi.org/10. 1038/nri.2017.1

38. Tang X, Feng YM, Ni JX, Zhang JY, Liu LM, Hu K, Wu XZ, Zhang JX, Chen JW, Zhang JC, Su J, Li YL, Zhao Y, Xie J, Ding Z, He XL, Wang W, Jin RH, Shi HZ, Sun B (2021) Early use of corticosteroid may prolong SARS-CoV-2 shedding in nonintensive care unit patients with COVID-19 pneumonia: a multicenter, single-blind, randomized control trial. Respiration 100(2): 116-126. https://doi.org/10.1159/000512063

39. Sanders JM, Monogue ML, Jodlowski TZ, Cutrell JB (2020) Pharmacologic treatments for coronavirus disease 2019 (COVID-19): a review. JAMA 323(18):1824-1836. https://doi. org/10.1001/jama.2020.6019

40. World Health Organisation (2021)COVID-19 vaccines: resolving deployment challenges. Bull World Health Organ 99(3):174-175. https://doi.org/10.2471/blt.21.020321

41. Troiano G, Nardi A (2021) Vaccine hesitancy in the era of COVID-19. Public Health 194:245-251. https://doi.org/10.1016/ j.puhe.2021.02.025

42. Paris C, Bénézit F, Geslin M, Polard E, Baldeyrou M, Turmel V, Tadié É, Garlantezec R, Tattevin P (2021)COVID-19 vaccine hesitancy among healthcare workers. Infect Dis Now. https://doi. org/10.1016/j.idnow.2021.04.001

43. Dzieciolowska S, Hamel D, Gadio S, Dionne M, Gagnon D, Robitaille L, Cook E, Caron I, Talib A, Parkes L, Dubé È, Longtin Y (2021)Covid-19 vaccine acceptance, hesitancy, and refusal among Canadian healthcare workers: a multicenter survey. Am J Infect Control. https://doi.org/10.1016/j.ajic.2021.04.079

44. Phillips N (2021) The coronavirus is here to stay - here's what that means. Nature 590(7846):382-384. https://doi.org/10.1038/ d41586-021-00396-2

45. Drury AN, Szent-Gyorgyi A (1929) The physiological activity of adenine compounds with especial reference to their action upon the mammalian heart. J Physiol 68(3):213-237. https://doi.org/10. 1113/jphysiol.1929.sp002608

46. Lohmann K (1929) Über die Pyrophosphatfraktion im Muskel. Naturwissenschaften 17(31):624-625. https://doi.org/10.1007/ BF01506215

47. Engelhardt WA, Ljubimowa MN (1939) Myosine and adenosinetriphosphatase. Nature 144(3650):668-669. https:// doi.org/10.1038/144668b0

48. Lipmann F (1940) A phosphorylated oxygenation product of pyruvic acid. J Biol Chem 134:463-464

49. Lipmann F (1944) Enzymatic synthesis of acetyl phosphate. J Biol Chem 155:55-70 
50. Lipmann F, Jones ME, Black S, Flynn RM (1953) The mechanism of the ATP-CoA-acetate reaction. J Cell Physiol Suppl 41(Suppl 1):109-112

51. Feldberg W, Hebb C (1948) The stimulating action of phosphate compounds on the perfused superior cervical ganglion of the cat. J Physiol 107(2):210-221

52. Holton P (1959) The liberation of adenosine triphosphate on antidromic stimulation of sensory nerves. J Physiol 145(3):494-504

53. Burnstock G (1972) Purinergic nerves. Pharmacol Rev 24(3):509581

54. Burnstock G (2012) Purinergic signalling: its unpopular beginning, its acceptance and its exciting future. Bioessays 34(3):218225. https://doi.org/10.1002/bies.201100130

55. Burnstock G (2014) Purinergic signalling: from discovery to current developments. ExpPhysiol 99(1):16-34

56. Di Virgilio F (1995) The P2Z purinoceptor: an intriguing role in immunity, inflammation and cell death. Immunol Today 16(11): 524-528. https://doi.org/10.1016/0167-5699(95)80045-x

57. Eltzschig HK, Sitkovsky MV, Robson SC (2012) Purinergic signaling during inflammation. N Engl J Med 367(24):2322-2333

58. Burnstock G (2007) Physiology and pathophysiology of purinergic neurotransmission. Physiol Rev 87(2):659-797. https://doi.org/10.1152/physrev.00043.2006

59. Patel AS, Reigada D, Mitchell CH, Bates SR, Margulies SS, Koval M (2005) Paracrine stimulation of surfactant secretion by extracellular ATP in response to mechanical deformation. Am J Physiol Lung Cell MolPhysiol 289(3):L489-L496

60. Hasan D, Blankman P, Nieman GF (2017) Purinergic signalling links mechanical breath profile and alveolar mechanics with the pro-inflammatory innate immune response causing ventilationinduced lung injury. Purinergic Signal 13(3):363-386. https:// doi.org/10.1007/s11302-017-9564-5

61. Hasan D, Satalin J, van der Zee P, Kollisch-Singule M, Blankman P, Shono A, Somhorst P, den Uil C, Meeder H, Kotani T, Nieman GF (2018) Excessive extracellular ATP desensitizes P2Y2 and P2X4 ATP receptors provoking surfactant impairment ending in ventilation-induced lung injury. Int J Mol Sci 19(4). https://doi. org/10.3390/ijms19041185

62. Takahara N, Ito S, Furuya K, Naruse K, Aso H, Kondo M, Sokabe M, Hasegawa Y (2014)Real-time imaging of ATP release induced by mechanical stretch in human airway smooth muscle cells. Am J Respir Cell Mol Biol 51(6):772-782. https://doi.org/10.1165/ remb.2014-0008OC

63. Furuya K, Tan JJ, Boudreault F, Sokabe M, Berthiaume Y, Grygorczyk R (2016)Real-time imaging of inflation-induced ATP release in the ex-vivo rat lung. Am J Phys Lung Cell Mol Phys. https://doi.org/10.1152/ajplung.00425.2015

64. Bodin P, Burnstock G (1995) Synergistic effect of acute hypoxia on flow-induced release of ATP from cultured endothelial cells. Experientia 51(3):256-259. https://doi.org/10.1007/bf01931108

65. Seminario-Vidal L, Kreda S, Jones L, O'Neal W, Trejo J, Boucher RC, Lazarowski ER (2009) Thrombin promotes release of ATP from lung epithelial cells through coordinated activation of rhoand Ca2+-dependent signaling pathways. J Biol Chem 284(31): 20638-20648. https://doi.org/10.1074/jbc.M109.004762

66. Guzman-Aranguez A, Perez de Lara MJ, Pintor J (2017) Hyperosmotic stress induces ATP release and changes in P2X7 receptor levels in human corneal and conjunctival epithelial cells. Purinergic Signal 13(2):249-258. https://doi.org/10.1007/ s11302-017-9556-5

67. Nandigama R, Padmasekar M, Wartenberg M, Sauer H (2006) Feed forward cycle of hypotonic stress-induced ATP release, purinergic receptor activation, and growth stimulation of prostate cancer cells. J Biol Chem 281(9):5686-5693. https://doi.org/10. 1074/jbc.M510452200
68. Cheung-Flynn J, Alvis BD, Hocking KM, Guth CM, Luo W, McCallister R, Chadalavada K, Polcz M, Komalavilas P, Brophy CM (2019) Normal saline solutions cause endothelial dysfunction through loss of membrane integrity, ATP release, and inflammatory responses mediated by $\mathrm{P} 2 \mathrm{X} 7 \mathrm{R} / \mathrm{p} 38$ MAPK/MK2 signaling pathways. PLoS One 14(8):e0220893. https://doi.org/10.1371/journal.pone.0220893

69. Bodin P, Burnstock G (1998) Increased release of ATP from endothelial cells during acute inflammation. Inflamm Res 47(8): 351-354. https://doi.org/10.1007/s000110050341

70. Okada SF, Ribeiro CM, Sesma JI, Seminario-Vidal L, Abdullah LH, van Heusden C, Lazarowski ER, Boucher RC (2013) Inflammation promotes airway epithelial ATP release via calcium-dependent vesicular pathways. Am J Respir Cell Mol Biol 49(5):814-820. https://doi.org/10.1165/rcmb.2012-0493OC

71. Kim KC, Zheng QX, Van-Seuningen I (1993) Involvement of a signal transduction mechanism in ATP-induced mucin release from cultured airway goblet cells. Am J Respir Cell Mol Biol 8(2):121-125. https://doi.org/10.1165/ajrcmb/8.2.121

72. Tozzi M, Larsen AT, Lange SC, Giannuzzo A, Andersen MN, Novak I (2018) The P2X7 receptor and pannexin-1 are involved in glucose-induced autocrine regulation in beta-cells. Sci Rep 8(1):8926. https://doi.org/10.1038/s41598-018-27281-9

73. Jacques-Silva MC, Correa-Medina M, Cabrera O, Rodriguez-Diaz R, Makeeva N, Fachado A, Diez J, Berman DM, Kenyon NS, Ricordi C, Pileggi A, Molano RD, Berggren PO, Caicedo A (2010)ATP-gated P2X3 receptors constitute a positive autocrine signal for insulin release in the human pancreatic beta cell. Proc Natl Acad Sci U S A 107(14):6465-6470. https://doi.org/10.1073/ pnas.0908935107

74. Okura D, Horishita T, Ueno S, Yanagihara N, Sudo Y, Uezono Y, Minami T, Kawasaki T, Sata T (2015) Lidocaine preferentially inhibits the function of purinergic P2X7 receptors expressed in Xenopus oocytes. Anesth Analg 120(3):597-605. https://doi.org/ 10.1213/ane.0000000000000585

75. Adinolfi E, Callegari MG, Ferrari D, Bolognesi C, Minelli M, Wieckowski MR, Pinton P, Rizzuto R, Di Virgilio F (2005) Basal activation of the $\mathrm{P} 2 \mathrm{X} 7 \mathrm{ATP}$ receptor elevates mitochondrial calcium and potential, increases cellular ATP levels, and promotes serum-independent growth. Mol Biol Cell 16(7):3260-3272. https://doi.org/10.1091/mbc.e04-11-1025

76. Ghazi K, Deng-Pichon U, Warnet JM, Rat P (2012) Hyaluronan fragments improve wound healing on in vitro cutaneous model through P2X7 purinoreceptor basal activation: role of molecular weight. PLoS One 7(11):e48351. https://doi.org/10.1371/journal. pone. 0048351

77. Adinolfi E, Callegari MG, Cirillo M, Pinton P, Giorgi C, Cavagna D, Rizzuto R, Di Virgilio F (2009) Expression of the P2X7 receptor increases the $\mathrm{Ca} 2+$ content of the endoplasmic reticulum, activates NFATc1, and protects from apoptosis. J Biol Chem 284(15): 10120-10128. https://doi.org/10.1074/jbc.M805805200

78. Amoroso F, Falzoni S, Adinolfi E, Ferrari D, Di Virgilio F (2012) The P2X7 receptor is a key modulator of aerobic glycolysis. Cell Death Dis 3:e370. https://doi.org/10.1038/cddis.2012.105

79. Cronstein BN, Daguma L, Nichols D, Hutchison AJ, Williams M (1990) The adenosine/neutrophil paradox resolved: human neutrophils possess both $\mathrm{A} 1$ and $\mathrm{A} 2$ receptors that promote chemotaxis and inhibit $\mathrm{O} 2$ generation, respectively. J Clin Invest 85(4): 1150-1157. https://doi.org/10.1172/jci1 14547

80. Rose FR, Hirschhorn R, Weissmann G, Cronstein BN (1988) Adenosine promotes neutrophil chemotaxis. J Exp Med 167(3): 1186-1194

81. Felsch A, Stocker K, Borchard U (1995) Phorbol ester-stimulated adherence of neutrophils to endothelial cells is reduced by adenosine A2 receptor agonists. J Immunol 155(1):333-338 
82. Thiel M, Chouker A (1995) Acting via A2 receptors, adenosine inhibits the production of tumor necrosis factor-alpha of endotoxin-stimulated human polymorphonuclear leukocytes. J Lab Clin Med 126(3):275-282

83. Salmon JE, Cronstein BN (1990) Fc gamma receptor-mediated functions in neutrophils are modulated by adenosine receptor occupancy. A1 receptors are stimulatory and $\mathrm{A} 2$ receptors are inhibitory. J Immunol 145(7):2235-2240

84. Zalavary S, Stendahl O, Bengtsson T (1994) The role of cyclic AMP, calcium and filamentous actin in adenosine modulation of Fc receptor-mediated phagocytosis in human neutrophils. Biochim Biophys Acta 1222(2):249-256

85. Zalavary S, Bengtsson T (1998) Adenosine inhibits actin dynamics in human neutrophils: evidence for the involvement of cAMP. Eur J Cell Biol 75(2):128-139. https://doi.org/10.1016/s01719335(98)80055-1

86. Xu X, Zheng S, Xiong Y, Wang X, Qin W, Zhang H, Sun B (2017) Adenosine effectively restores endotoxin-induced inhibition of human neutrophil chemotaxis via A1 receptor-p38 pathway. Inflamm Res 66(4):353-364. https://doi.org/10.1007/ s00011-016-1021-3

87. Chen L, Fredholm BB, Jondal M (2008) Adenosine, through the A1 receptor, inhibits vesicular MHC class I cross-presentation by resting DC. Mol Immunol 45(8):2247-2254. https://doi.org/10. 1016/j.molimm.2007.11.016

88. Schnurr M, Toy T, Shin A, Hartmann G, Rothenfusser S, Soellner J, Davis ID, Cebon J, Maraskovsky E (2004) Role of adenosine receptors in regulating chemotaxis and cytokine production of plasmacytoid dendritic cells. Blood 103(4):1391-1397. https:// doi.org/10.1182/blood-2003-06-1959

89. Figueiro F, Muller L, Funk S, Jackson EK, Battastini AM, Whiteside TL (2016) Phenotypic and functional characteristics of CD39high human regulatory B cells (Breg). Oncoimmunology 5(2):e1082703. https://doi.org/10.1080/ 2162402x.2015.1082703

90. Ohtsuka T, Changelian PS, Bouis D, Noon K, Harada H, Lama VN, Pinsky DJ (2010)Ecto-5'-nucleotidase(CD73) attenuates allograft airway rejection through adenosine $2 \mathrm{~A}$ receptor stimulation. J Immunol 185(2):1321-1329. https://doi.org/10.4049/ jimmunol.0901847

91. Link AA, Kino T, Worth JA, McGuire JL, Crane ML, Chrousos GP, Wilder RL, Elenkov IJ (2000)Ligand-activation of the adenosine A2a receptors inhibits IL-12 production by human monocytes. J Immunol 164(1):436-442

92. Zhang JG, Hepburn L, Cruz G, Borman RA, Clark KL (2005) The role of adenosine $\mathrm{A} 2 \mathrm{~A}$ and $\mathrm{A} 2 \mathrm{~B}$ receptors in the regulation of TNF-alpha production by human monocytes. Biochem Pharmacol 69(6):883-889. https://doi.org/10.1016/j.bcp.2004.12. 008

93. Thiel M, Chambers JD, Chouker A, Fischer S, Zourelidis C, Bardenheuer HJ, Arfors KE, Peter K (1996) Effect of adenosine on the expression of beta(2) integrins and L-selectin of human polymorphonuclear leukocytes in vitro. J Leukoc Biol 59(5): 671-682

94. Wollner A, Wollner S, Smith JB (1993) Acting via A2 receptors, adenosine inhibits the upregulation of Mac-1 (Cd11b/CD18) expression on FMLP-stimulated neutrophils. Am J Respir Cell Mol Biol 9(2):179-185. https://doi.org/10.1165/ajrcmb/9.2.179

95. Cadieux JS, Leclerc P, St-Onge M, Dussault AA, Laflamme C, Picard S, Ledent C, Borgeat P, Pouliot M (2005) Potentiation of neutrophil cyclooxygenase- 2 by adenosine: an early antiinflammatory signal. J Cell Sci 118(Pt 7):1437-1447. https://doi. org $/ 10.1242 /$ jcs. 01737

96. Sullivan GW, Linden J, Buster BL, Scheld WM (1999) Neutrophil $\mathrm{A} 2 \mathrm{~A}$ adenosine receptor inhibits inflammation in a rat model of meningitis: synergy with the type IV phosphodiesterase inhibitor, rolipram. J Infect Dis 180(5):1550-1560. https://doi.org/10.1086/ 315084

97. McColl SR, St-Onge M, Dussault AA, Laflamme C, Bouchard L, Boulanger J, Pouliot M (2006) Immunomodulatory impact of the A2A adenosine receptor on the profile of chemokines produced by neutrophils. FASEB J 20(1):187-189. https://doi.org/10.1096/fj. 05-4804fje

98. Krump E, Lemay G, Borgeat P (1996) Adenosine A2 receptorinduced inhibition of leukotriene B4 synthesis in whole blood ex vivo. Br J Pharmacol 117(8):1639-1644

99. Krump E, Picard S, Mancini J, Borgeat P (1997) Suppression of leukotriene B4 biosynthesis by endogenous adenosine in ligandactivated human neutrophils. J Exp Med 186(8):1401-1406

100. Surette ME, Krump E, Picard S, Borgeat P (1999) Activation of leukotriene synthesis in human neutrophils by exogenous arachidonic acid: inhibition by adenosine $\mathrm{A}(2 \mathrm{a})$ receptor agonists and crucial role of autocrine activation by leukotriene $\mathrm{B}(4)$. Mol Pharmacol 56(5):1055-1062

101. Flamand N, Boudreault S, Picard S, Austin M, Surette ME, Plante H, Krump E, Vallee MJ, Gilbert C, Naccache P, Laviolette M, Borgeat P (2000) Adenosine, a potent natural suppressor of arachidonic acid release and leukotriene biosynthesis in human neutrophils. Am J Respir Crit Care Med 161(2 Pt 2):S88-S94. https:// doi.org/10.1164/ajrccm.161.supplement_1.1tta-18

102. Flamand N, Surette ME, Picard S, Bourgoin S, Borgeat P (2002) Cyclic AMP-mediated inhibition of 5-lipoxygenase translocation and leukotriene biosynthesis in human neutrophils. Mol Pharmacol 62(2):250-256

103. Sullivan GW, Rieger JM, Scheld WM, Macdonald TL, Linden J (2001) Cyclic AMP-dependent inhibition of human neutrophil oxidative activity by substituted 2-propynylcyclohexyl adenosine A(2A) receptor agonists. Br J Pharmacol 132(5):1017-1026. https://doi.org/10.1038/sj.bjp.0703893

104. Anderson R, Visser SS, Ramafi G, Theron AJ (2000) Accelerated resequestration of cytosolic calcium and suppression of the proinflammatory activities of human neutrophils by CGS 21680 in vitro. Br J Pharmacol 130(4):717-724. https://doi.org/10. 1038/sj.bjp.0703344

105. Richter J (1992) Effect of adenosine analogues and cAMP-raising agents on TNF-, GM-CSF-, and chemotactic peptide-induced degranulation in single adherent neutrophils. J Leukoc Biol 51(3): $270-275$

106. Visser SS, Theron AJ, Ramafi G, Ker JA, Anderson R (2000) Apparent involvement of the $\mathrm{A}(2 \mathrm{~A})$ subtype adenosine receptor in the anti-inflammatory interactions of CGS 21680 , cyclopentyladenosine, and IB-MECA with human neutrophils. Biochem Pharmacol 60(7):993-999

107. Walker BA, Rocchini C, Boone RH, Ip S, Jacobson MA (1997) Adenosine A2a receptor activation delays apoptosis in human neutrophils. J Immunol 158(6):2926-2931

108. Liu YW, Yang T, Zhao L, Ni Z, Yang N, He F, Dai SS (2016) Activation of adenosine $2 \mathrm{~A}$ receptor inhibits neutrophil apoptosis in an autophagy-dependent manner in mice with systemic inflammatory response syndrome. Sci Rep 6:33614. https://doi.org/10. 1038/srep33614

109. Ryzhov S, Goldstein AE, Matafonov A, Zeng D, Biaggioni I, Feoktistov I (2004)Adenosine-activated mast cells induce IgE synthesis by B lymphocytes: an A2B-mediated process involving Th2 cytokines IL-4 and IL-13 with implications for asthma. J Immunol 172(12):7726-7733

110. Kreckler LM, Gizewski E, Wan TC, Auchampach JA (2009) Adenosine suppresses lipopolysaccharide-induced tumor necrosis factor-alpha production by murine macrophages through a protein kinase A- and exchange protein activated by cAMP-independent signaling pathway. J Pharmacol Exp Ther 331(3):1051-1061. https://doi.org/10.1124/jpet.109.157651 
111. Hassanian SM, Dinarvand P, Rezaie AR (2014) Adenosine regulates the proinflammatory signaling function of thrombin in endothelial cells. J Cell Physiol 229(9):1292-1300. https://doi.org/10. $1002 /$ jcp. 24568

112. Zarek PE, Huang CT, Lutz ER, Kowalski J, Horton MR, Linden J, Drake CG, Powell JD (2008) A2A receptor signaling promotes peripheral tolerance by inducing T-cell anergy and the generation of adaptive regulatory T cells. Blood 111 (1):251-259. https://doi. org/10.1182/blood-2007-03-081646

113. Csoka B, Himer L, Selmeczy Z, Vizi ES, Pacher P, Ledent C, Deitch EA, Spolarics Z, Nemeth ZH, Hasko G (2008) Adenosine A2A receptor activation inhibits $\mathrm{T}$ helper 1 and $\mathrm{T}$ helper 2 cell development and effector function. FASEB J 22(10): 3491-3499. https://doi.org/10.1096/fj.08-107458

114. Alam MS, Kurtz CC, Wilson JM, Burnette BR, Wiznerowicz EB, Ross WG, Rieger JM, Figler RA, Linden J, Crowe SE, Ernst PB (2009) A2A adenosine receptor (AR) activation inhibits proinflammatory cytokine production by human CD4+ helper T cells and regulates Helicobacter-induced gastritis and bacterial persistence. Mucosal Immunol 2(3):232-242. https://doi.org/10.1038/ mi.2009.4

115. Hasko G, Kuhel DG, Chen JF, Schwarzschild MA, Deitch EA, Mabley JG, Marton A, Szabo C (2000) Adenosine inhibits IL-12 and TNF-[alpha] production via adenosine A2a receptordependent and independent mechanisms. FASEB J 14(13): 2065-2074. https://doi.org/10.1096/fj.99-0508com

116. Erdmann AA, Gao ZG, Jung U, Foley J, Borenstein T, Jacobson KA, Fowler DH (2005) Activation of Th1 and Tc1 cell adenosine A2A receptors directly inhibits IL-2 secretion in vitro and IL-2driven expansion in vivo. Blood 105(12):4707-4714. https://doi. org/10.1182/blood-2004-04-1407

117. Lappas CM, Rieger JM, Linden J (2005) A2A adenosine receptor induction inhibits IFN-gamma production in murine CD4+ T cells. J Immunol 174(2):1073-1080

118. Ohta A, Kini R, Ohta A, Subramanian M, Madasu M, Sitkovsky M (2012) The development and immunosuppressive functions of CD4(+) CD25(+) FoxP3(+) regulatory T cells are under influence of the adenosine-A2A adenosine receptor pathway. Front Immunol 3:190. https://doi.org/10.3389/fimmu.2012.00190

119. Huang X, He Y, Chen Y, Wu P, Gui D, Cai H, Chen A, Chen M, Dai C, Yao D, Wang L (2016) Baicalin attenuates bleomycininduced pulmonary fibrosis via adenosine $\mathrm{A} 2 \mathrm{a}$ receptor related TGF-beta1-inducedERK1/2 signaling pathway. BMC Pulm Med 16(1):132. https://doi.org/10.1186/s12890-016-0294-1

120. Guillén-Gómez E, Silva I, Serra N, Caballero F, Leal J, Breda A, San Martín R, Pastor-Anglada M, Ballarín JA, Guirado L, DíazEncarnación MM (2020) From inflammation to the onset of fibrosis through $\mathrm{A}(2 \mathrm{~A})$ receptors in kidneys from deceased donors. Int J Mol Sci 21(22). https://doi.org/10.3390/ijms21228826

121. Shi L, Feng M, Du S, Wei X, Song H, Yixin X, Song J, Wenxian $\mathrm{G}$ (2019) Adenosine generated by regulatory $\mathrm{T}$ cells induces CD8(+) T cell exhaustion in gastric cancer through A2aR pathway. Biomed Res Int 2019:4093214. https://doi.org/10.1155/ 2019/4093214

122. Barbera-Cremades M, Baroja-Mazo A, Pelegrin P (2016) Purinergic signaling during macrophage differentiation results in M2 alternative activated macrophages. J Leukoc Biol 99(2):289 299. https://doi.org/10.1189/jlb.1A0514-267RR

123. Csoka B, Selmeczy Z, Koscso B, Nemeth ZH, Pacher P, Murray PJ, Kepka-Lenhart D, Morris SM Jr, Gause WC, Leibovich SJ, Hasko G (2012) Adenosine promotes alternative macrophage activation via A2A and A2B receptors. FASEB J 26(1):376-386. https://doi.org/10.1096/fj.11-190934

124. Ferrante CJ, Pinhal-Enfield G, Elson G, Cronstein BN, Hasko G, Outram S, Leibovich SJ (2013) The adenosine-dependent angiogenic switch of macrophages to an M2-like phenotype is independent of interleukin-4 receptor alpha (IL-4Ralpha) signaling. Inflammation 36(4):921-931. https://doi.org/10.1007/ s10753-013-9621-3

125. Koscso B, Csoka B, Kokai E, Nemeth ZH, Pacher P, Virag L, Leibovich SJ, Hasko G (2013) Adenosine augments IL-10induced STAT3 signaling in M2c macrophages. J Leukoc Biol 94(6):1309-1315. https://doi.org/10.1189/jlb.0113043

126. Hasko G, Pacher P (2012) Regulation of macrophage function by adenosine. Arterioscler Thromb Vasc Biol 32(4):865-869. https:// doi.org/10.1161/atvbaha.111.226852

127. Koroskenyi K, Kiss B, Szondy Z (2016) Adenosine A2A receptor signaling attenuates LPS-induced pro-inflammatory cytokine formation of mouse macrophages by inducing the expression of DUSP1. Biochim Biophys Acta 1863(7 Pt A):1461-1471. https://doi.org/10.1016/j.bbamcr.2016.04.003

128. Majumdar S, Aggarwal BB (2003) Adenosine suppresses activation of nuclear factor-kappaB selectively induced by tumor necrosis factor in different cell types. Oncogene 22(8):1206-1218. https://doi.org/10.1038/sj.onc.1206184

129. Mirakaj V, Thix CA, Laucher S, Mielke C, Morote-Garcia JC, Schmit MA, Henes J, Unertl KE, Kohler D, Rosenberger P (2010)Netrin-1 dampens pulmonary inflammation during acute lung injury. Am J Respir Crit Care Med 181(8):815-824. https:// doi.org/10.1164/rccm.200905-0717OC

130. Aherne CM, Collins CB, Masterson JC, Tizzano M, Boyle TA, Westrich JA, Parnes JA, Furuta GT, Rivera-Nieves J, Eltzschig HK (2012) Neuronal guidance molecule netrin-1 attenuates inflammatory cell trafficking during acute experimental colitis. Gut 61(5):695-705. https://doi.org/10.1136/gutjnl-2011-300012

131. van der Hoeven D, Wan TC, Gizewski ET, Kreckler LM, Maas JE, Van Orman J, Ravid K, Auchampach JA (2011) A role for the low-affinity A2B adenosine receptor in regulating superoxide generation by murine neutrophils. J Pharmacol Exp Ther 338(3): 1004-1012. https://doi.org/10.1124/jpet.111.181792

132. Nemeth ZH, Lutz CS, Csoka B, Deitch EA, Leibovich SJ, Gause WC, Tone M, Pacher P, Vizi ES, Hasko G (2005) Adenosine augments IL-10 production by macrophages through an A2B receptor-mediated posttranscriptional mechanism. J Immunol 175(12):8260-8270

133. Novitskiy SV, Ryzhov S, Zaynagetdinov R, Goldstein AE, Huang Y, Tikhomirov OY, Blackburn MR, Biaggioni I, Carbone DP, Feoktistov I, Dikov MM (2008) Adenosine receptors in regulation of dendritic cell differentiation and function. Blood 112(5):18221831. https://doi.org/10.1182/blood-2008-02-136325

134. Wilson JM, Kurtz CC, Black SG, Ross WG, Alam MS, Linden J, Ernst PB (2011) The A2B adenosine receptor promotes Th17 differentiation via stimulation of dendritic cell IL-6. J Immunol 186(12):6746-6752. https://doi.org/10.4049/jimmunol.1100117

135. Liang D, Zuo A, Shao H, Chen M, Kaplan HJ, Sun D (2015) A2B adenosine receptor activation switches differentiation of bone marrow cells to a $\mathrm{CD} 11 \mathrm{c}(+) \mathrm{Gr}-1(+)$ dendritic cell subset that promotes the Th17 response. Immun Inflamm Dis 3(4):360-373. https://doi.org/10.1002/iid3.74

136. Karmouty-Quintana H, Philip K, Acero LF, Chen NY, Weng T, Molina JG, Luo F, Davies J, Le NB, Bunge I, Volcik KA, Le TT, Johnston RA, Xia Y, Eltzschig HK, Blackburn MR (2015) Deletion of ADORA2B from myeloid cells dampens lung fibrosis and pulmonary hypertension. FASEB J 29(1):50-60. https://doi. org/10.1096/fj.14-260182

137. Eckle T, Grenz A, Laucher S, Eltzschig HK (2008) A2B adenosine receptor signaling attenuates acute lung injury by enhancing alveolar fluid clearance in mice. J Clin Invest 118(10):3301-3315

138. Grant MB, Tarnuzzer RW, Caballero S, Ozeck MJ, Davis MI, Spoerri PE, Feoktistov I, Biaggioni I, Shryock JC, Belardinelli L (1999) Adenosine receptor activation induces vascular endothelial 
growth factor in human retinal endothelial cells. Circ Res 85(8): 699-706

139. Zhong $\mathrm{H}, \mathrm{Wu} \mathrm{Y}$, Belardinelli L, Zeng D (2006) A2B adenosine receptors induce IL-19 from bronchial epithelial cells, resulting in TNF-alpha increase. Am J Respir Cell Mol Biol 35(5):587-592. https://doi.org/10.1165/rcmb.2005-0476OC

140. Wilkinson PF, Farrell FX, Morel D, Law W, Murphy S (2016) Adenosine signaling increases proinflammatory and profibrotic mediators through activation of a functional adenosine $2 \mathrm{~B}$ receptor in renal fibroblasts. Ann Clin Lab Sci 46(4):339-345

141. Zhou Y, Murthy JN, Zeng D, Belardinelli L, Blackburn MR (2010) Alterations in adenosine metabolism and signaling in patients with chronic obstructive pulmonary disease and idiopathic pulmonary fibrosis. PLoS One 5(2):e9224. https://doi.org/10. 1371/journal.pone.0009224

142. Huang L, Fan J, Chen YX, Wang JH (2020) Inhibition of A(2B) Adenosine receptor attenuates intestinal injury in a rat model of necrotizing enterocolitis. Mediat Inflamm 2020:1562973. https:// doi.org/10.1155/2020/1562973

143. Reyes AWB, Vu SH, Huy TXN, Min W, Lee HJ, Chang HH, Lee JH, Kim S (2020) Adenosine receptor Adora2b antagonism attenuates Brucella abortus 544 infection in professional phagocyte RAW 264.7 cells and BALB/c mice. Vet Microbiol 242:108586. https://doi.org/10.1016/j.vetmic.2020.108586

144. Feoktistov I, Ryzhov S, Goldstein AE, Biaggioni I (2003) Mast cell-mediated stimulation of angiogenesis: cooperative interaction between A2B and A3 adenosine receptors. Circ Res 92(5):485492. https://doi.org/10.1161/01.res.0000061572.10929.2d

145. Joos G, Jakim J, Kiss B, Szamosi R, Papp T, Felszeghy S, Saghy T, Nagy G, Szondy Z (2017) Involvement of adenosine A3 receptors in the chemotactic navigation of macrophages towards apoptotic cells. Immunol Lett 183:62-72. https://doi.org/10.1016/j. imlet.2017.02.002

146. Chen Y, Corriden R, Inoue Y, Yip L, Hashiguchi N, Zinkernagel A, Nizet V, Insel PA, Junger WG (2006) ATP release guides neutrophil chemotaxis via $\mathrm{P} 2 \mathrm{Y} 2$ and $\mathrm{A} 3$ receptors. Science 314(5806):1792-1795

147. Inoue Y, Chen Y, Hirsh MI, Yip L, Junger WG (2008) A3 and $\mathrm{P} 2 \mathrm{Y} 2$ receptors control the recruitment of neutrophils to the lungs in a mouse model of sepsis. Shock 30(2):173-177. https://doi.org/ 10.1097/shk.0b013e318160dad4

148. Tweedy L, Knecht DA, Mackay GM, Insall RH (2016)Selfgenerated chemoattractant gradients: attractant depletion extends the range and robustness of chemotaxis. PLoS Biol 14(3): e1002404. https://doi.org/10.1371/journal.pbio.1002404

149. Tweedy L, Susanto O, Insall RH (2016)Self-generated chemotactic gradients-cells steering themselves. Curr Opin Cell Biol 42:4651. https://doi.org/10.1016/j.ceb.2016.04.003

150. Dona E, Barry JD, Valentin G, Quirin C, Khmelinskii A, Kunze A, Durdu S, Newton LR, Fernandez-Minan A, Huber W, Knop M, Gilmour D (2013) Directional tissue migration through a selfgenerated chemokine gradient. Nature 503(7475):285-289. https://doi.org/10.1038/nature12635

151. So H (2016) Where to go: breaking the symmetry in cell motility. PLoS Biol 14(5):e1002463. https://doi.org/10.1371/journal.pbio. 1002463

152. Moissoglu K, Majumdar R, Parent CA (2014) Cell migration: sinking in a gradient. Curr Biol 24(1):R23-R25. https://doi.org/ 10.1016/j.cub.2013.10.075

153. Lee JY, Jhun BS, Oh YT, Lee JH, Choe W, Baik HH, Ha J, Yoon KS, Kim SS, Kang I (2006) Activation of adenosine A3 receptor suppresses lipopolysaccharide-induced TNF-alpha production through inhibition of PI 3-kinase/Akt and NF-kappaB activation in murine BV2 microglial cells. Neurosci Lett 396(1):1-6. https:// doi.org/10.1016/j.neulet.2005.11.004
154. Ren T, Qiu Y, Wu W, Feng X, Ye S, Wang Z, Tian T, He Y, Yu C, Zhou Y (2014) Activation of adenosine A3 receptor alleviates TNF-alpha-induced inflammation through inhibition of the NFkappaB signaling pathway in human colonic epithelial cells. Mediat Inflamm 2014:818251. https://doi.org/10.1155/2014/ 818251

155. Hoskin DW, Butler JJ, Drapeau D, Haeryfar SM, Blay J (2002) Adenosine acts through an $\mathrm{A} 3$ receptor to prevent the induction of murine anti-CD3-activated killer T cells. Int J Cancer 99(3):386395. https://doi.org/10.1002/ijc. 10325

156. Ferreira-Silva J, Aires ID, Boia R, Ambrósio AF, Santiago AR (2020) Activation of adenosine A(3) receptor inhibits microglia reactivity elicited by elevated pressure. Int J Mol Sci 21(19). https://doi.org/10.3390/ijms21197218

157. Morschl E, Molina JG, Volmer JB, Mohsenin A, Pero RS, Hong JS, Kheradmand F, Lee JJ, Blackburn MR (2008) A3 adenosine receptor signaling influences pulmonary inflammation and fibrosis. Am J Respir Cell Mol Biol 39(6):697-705. https://doi.org/10. 1165/rcmb.2007-0419OC

158. Ren TH, Lv MM, An XM, Leung WK, Seto WK (2020) Activation of adenosine $\mathrm{A} 3$ receptor inhibits inflammatory cytokine production in colonic mucosa of patients with ulcerative colitis by down-regulating the nuclear factor-kappa B signaling. J Dig Dis 21(1):38-45. https://doi.org/10.1111/1751-2980.12831

159. Oury C, Lecut C, Hego A, Wera O, Delierneux C (2015) Purinergic control of inflammation and thrombosis: role of P2X1 receptors. Comput Struct Biotechnol J 13:106-110. https://doi.org/10.1016/j.csbj.2014.11.008

160. Alarcón P, Manosalva C, Quiroga J, Belmar I, Álvarez K, Díaz G, Taubert A, Hermosilla C, Carretta MD, Burgos RA, Hidalgo MA (2020) Oleic and linoleic acids induce the release of neutrophil extracellular traps via pannexin 1-dependent ATP release and P2X1 receptor activation. Front Vet Sci 7:260. https://doi.org/10. 3389/fvets.2020.00260

161. Woehrle T, Yip L, Elkhal A, Sumi Y, Chen Y, Yao Y, Insel PA, Junger WG (2010)Pannexin-1 hemichannel-mediated ATP release together with $\mathrm{P} 2 \mathrm{X} 1$ and $\mathrm{P} 2 \mathrm{X} 4$ receptors regulate T-cell activation at the immune synapse. Blood 116(18):3475-3484. https://doi.org/10.1182/blood-2010-04-277707

162. Bulanova E, Budagian V, Orinska Z, Koch-Nolte F, Haag F, Bulfone-Paus S (2009) ATP induces P2X7 receptor-independent cytokine and chemokine expression through $\mathrm{P} 2 \mathrm{X} 1$ and $\mathrm{P} 2 \mathrm{X} 3$ receptors in murine mast cells (Article retracted in 2011 due to figure irregularities). J Leukoc Biol 85(4):692-702. https://doi. org/10.1189/jlb.0808470

163. Manohar M, Hirsh MI, Chen Y, Woehrle T, Karande AA, Junger WG (2012) ATP release and autocrine signaling through P2X4 receptors regulate gammadelta $\mathrm{T}$ cell activation. J Leukoc Biol 92(4):787-794. https://doi.org/10.1189/jlb.0312121

164. Vazquez-Villoldo N, Domercq M, Martin A, Llop J, GomezVallejo V, Matute C (2014) P2X4 receptors control the fate and survival of activated microglia. Glia 62(2):171-184. https://doi. org/10.1002/glia.22596

165. Ledderose C, Liu K, Kondo Y, Slubowski CJ, Dertnig T, Denicoló S, Arbab M, Hubner J, Konrad K, Fakhari M, Lederer JA, Robson SC, Visner GA, Junger WG (2018) Purinergic P2X4 receptors and mitochondrial ATP production regulate T cell migration. J Clin Invest 128(8):3583-3594. https://doi.org/10.1172/ jci120972

166. Nguyen HM, di Lucente J, Chen YJ, Cui Y, Ibrahim RH, Pennington MW, Jin LW, Maezawa I, Wulff H (2020) Biophysical basis for Kv1.3 regulation of membrane potential changes induced by P2X4-mediated calcium entry in microglia. Glia 68(11):2377-2394. https://doi.org/10.1002/glia.23847

167. Ledderose C, Bromberger S, Slubowski CJ, Sueyoshi K, Junger WG (2020) Frontline Science: P2Y11 receptors support T cell 
activation by directing mitochondrial trafficking to the immune synapse. J Leukoc Biol. https://doi.org/10.1002/jlb.2hi0520-191r

168. Ledderose C, Bromberger S, Slubowski CJ, Sueyoshi K, Aytan D, Shen Y, Junger WG (2020) The purinergic receptor P2Y11 choreographs the polarization, mitochondrial metabolism, and migration of T lymphocytes. Sci Signal 13(651). https://doi.org/10. 1126/scisignal.aba3300

169. Cekic C, Linden J (2016) Purinergic regulation of the immune system. Nat Rev Immunol 16(3):177-192

170. Lee BH, Hwang DM, Palaniyar N, Grinstein S, Philpott DJ, Hu J (2012) Activation of P2X(7) receptor by ATP plays an important role in regulating inflammatory responses during acute viral infection. PLoS One 7(4):e35812. https://doi.org/10.1371/journal. pone. 0035812

171. Jo EK, Kim JK, Shin DM, Sasakawa C (2016) Molecular mechanisms regulating NLRP3 inflammasome activation. Cell Mol Immunol 13(2):148-159

172. Latz E, Xiao TS, Stutz A (2013) Activation and regulation of the inflammasomes. Nat Rev Immunol 13(6):397-411. https://doi. org/10.1038/nri3452

173. Sakaki H, Fujiwaki T, Tsukimoto M, Kawano A, Harada H, Kojima S (2013) P2X4 receptor regulates P2X7 receptordependent IL-1beta and IL-18 release in mouse bone marrowderived dendritic cells. Biochem Biophys Res Commun 432(3): 406-411. https://doi.org/10.1016/j.bbrc.2013.01.135

174. Luna-Gomes T, Santana PT, Coutinho-Silva R (2015)Silicainduced inflammasome activation in macrophages: role of ATP and P2X7 receptor. Immunobiology 220(9):1101-1106. https:// doi.org/10.1016/j.imbio.2015.05.004

175. Karmakar M, Katsnelson MA, Dubyak GR, Pearlman E (2016) Neutrophil P2X7 receptors mediate NLRP3 inflammasomedependent IL-1beta secretion in response to ATP. Nat Commun 7:10555. https://doi.org/10.1038/ncomms 10555

176. Eleftheriadis T, Pissas G, Karioti A, Antoniadi G, Golfinopoulos S, Liakopoulos V, Mamara A, Speletas M, Koukoulis G, Stefanidis I (2013) Uric acid induces caspase-1 activation, IL1 beta secretion and $\mathrm{P} 2 \mathrm{X} 7$ receptor dependent proliferation in primary human lymphocytes. Hippokratia 17(2):141-145

177. Jeong YH, Walsh MC, Yu J, Shen H, Wherry EJ, Choi Y (2020) Mice lacking the purinergic receptor P2X5 exhibit defective inflammasome activation and early susceptibility to listeria monocytogenes. J Immunol 205(3):760-766. https://doi.org/10. 4049/jimmunol.1901423

178. Wiley JS, Gu BJ (2012) A new role for the P2X7 receptor: a scavenger receptor for bacteria and apoptotic cells in the absence of serum and extracellular ATP. Purinergic Signal 8(3):579-586. https://doi.org/10.1007/s11302-012-9308-5

179. Gu BJ, Saunders BM, Petrou S, Wiley JS (2011) P2X(7) is a scavenger receptor for apoptotic cells in the absence of its ligand, extracellular ATP. J Immunol 187(5):2365-2375. https://doi.org/ 10.4049/jimmunol.1101178

180. Brandao-Burch A, Key ML, Patel JJ, Arnett TR, Orriss IR (2012) The $\mathrm{P} 2 \mathrm{X} 7$ receptor is an important regulator of extracellular ATP levels. Front Endocrinol (Lausanne) 3:41. https://doi.org/10.3389/ fendo.2012.00041

181. Gutierrez-Martin Y, Bustillo D, Gomez-Villafuertes R, SanchezNogueiro J, Torregrosa-Hetland C, Binz T, Gutierrez LM, MirasPortugal MT, Artalejo AR (2011) P2X7 receptors trigger ATP exocytosis and modify secretory vesicle dynamics in neuroblastoma cells. J Biol Chem 286(13):11370-11381. https://doi.org/10. 1074/jbc.M110.139410

182. Suadicani SO, Brosnan CF, Scemes E (2006) P2X7 receptors mediate ATP release and amplification of astrocytic intercellular Ca2+ signaling. J Neurosci 26(5):1378-1385. https://doi.org/10. 1523/jneurosci.3902-05.2006
183. Henriquez M, Herrera-Molina R, Valdivia A, Alvarez A, Kong M, Munoz N, Eisner V, Jaimovich E, Schneider P, Quest AF, Leyton L (2011) ATP release due to Thy-1-integrin binding induces P2X7-mediated calcium entry required for focal adhesion formation. J Cell Sci 124(Pt 9):1581-1588. https://doi.org/10.1242/jcs. 073171

184. Mishra A, Chintagari NR, Guo Y, Weng T, Su L, Liu L (2011) Purinergic P2X7 receptor regulates lung surfactant secretion in a paracrine manner. J Cell Sci 124(Pt 4):657-668

185. Ohshima Y, Tsukimoto M, Takenouchi T, Harada H, Suzuki A, Sato M, Kitani H, Kojima S (2010)gamma-Irradiation induces P2X(7) receptor-dependent ATP release from B16 melanoma cells. Biochim Biophys Acta 1800(1):40-46. https://doi.org/10. 1016/j.bbagen.2009.10.008

186. Johnsen B, Kaschubowski KE, Nader S, Schneider E, Nicola JA, Fliegert R, Wolf IMA, Guse AH, Nikolaev VO, Koch-Nolte F, Haag F (2019)P2X7-mediated ATP secretion is accompanied by depletion of cytosolic ATP. Purinergic Signal 15(2):155-166. https://doi.org/10.1007/s11302-019-09654-5

187. Sáez PJ, Vargas P, Shoji KF, Harcha PA, Lennon-Duménil AM, Sáez JC (2017) ATP promotes the fast migration of dendritic cells through the activity of pannexin 1 channels and $\mathrm{P} 2 \mathrm{X}(7)$ receptors. Sci Signal 10(506). https://doi.org/10.1126/scisignal.aah7107

188. Gilbert SM, Oliphant CJ, Hassan S, Peille AL, Bronsert P, Falzoni S, Di Virgilio F, McNulty S, Lara R (2019) ATP in the tumour microenvironment drives expression of $\mathrm{nfP} 2 \mathrm{X} 7$, a key mediator of cancer cell survival. Oncogene 38(2):194-208. https://doi.org/10. 1038/s41388-018-0426-6

189. Pellegatti P, Falzoni S, Donvito G, Lemaire I, Di Virgilio F (2011) $\mathrm{P} 2 \mathrm{X} 7$ receptor drives osteoclast fusion by increasing the extracellular adenosine concentration. FASEB J 25(4):1264-1274. https:// doi.org/10.1096/fj.10-169854

190. Schenk U, Frascoli M, Proietti M, Geffers R, Traggiai E, Buer J, Ricordi C, Westendorf AM, Grassi F (2011) ATP inhibits the generation and function of regulatory $\mathrm{T}$ cells through the activation of purinergic P2X receptors. Sci Signal 4(162):ra12. https:// doi.org/10.1126/scisignal.2001270

191. Figliuolo VR, Savio LEB, Safya H, Nanini H, Bernardazzi C, Abalo A, de Souza HSP, Kanellopoulos J, Bobe P, Coutinho C, Coutinho-Silva R (2017) P2X7 receptor promotes intestinal inflammation in chemically induced colitis and triggers death of mucosal regulatory $\mathrm{T}$ cells. Biochim Biophys Acta Mol basis Dis 1863(6):1183-1194. https://doi.org/10.1016/j.bbadis.2017. 03.004

192. Koo TY, Lee JG, Yan JJ, Jang JY, Ju KD, Han M, Oh KH, Ahn C, Yang J (2017) The P2X7 receptor antagonist, oxidized adenosine triphosphate, ameliorates renal ischemia-reperfusion injury by expansion of regulatory T cells. Kidney Int 92(2):415-431. https:// doi.org/10.1016/j.kint.2017.01.031

193. Frascoli M, Marcandalli J, Schenk U, Grassi F (2012) Purinergic P2X7 receptor drives T cell lineage choice and shapes peripheral $\gamma \delta$ cells. J Immunol 189(1):174-180. https://doi.org/10.4049/ jimmunol.1101582

194. Romagnani A, Rottoli E, Mazza EMC, Rezzonico-Jost T, De Ponte CB, Proietti M, Perotti M, Civanelli E, Perruzza L, Catapano AL, Baragetti A, Tenedini E, Tagliafico E, Falzoni S, Di Virgilio F, Norata GD, Bicciato S, Grassi F (2020) P2X7 Receptor activity limits accumulation of $\mathrm{T}$ cells within tumors. Cancer Res 80(18):3906-3919. https://doi.org/10.1158/00085472.can-19-3807

195. Verhoef PA, Estacion M, Schilling W, Dubyak GR (2003) P2X7 receptor-dependent blebbing and the activation of Rho-effector kinases, caspases, and IL-1 beta release. J Immunol 170(11): 5728-5738. https://doi.org/10.4049/jimmunol.170.11.5728

196. Pfeiffer ZA, Aga M, Prabhu U, Watters JJ, Hall DJ, Bertics PJ (2004) The nucleotide receptor $\mathrm{P} 2 \mathrm{X} 7$ mediates actin 
reorganization and membrane blebbing in RAW 264.7 macrophages via p38 MAP kinase and Rho. J Leukoc Biol 75(6): 1173-1182. https://doi.org/10.1189/jlb.1203648

197. Gu BJ, Wiley JS (2006) Rapid ATP-induced release of matrix metalloproteinase 9 is mediated by the $\mathrm{P} 2 \mathrm{X} 7$ receptor. Blood 107(12):4946-4953. https://doi.org/10.1182/blood-2005-07-2994

198. de Torre-Minguela C, Barbera-Cremades M, Gomez AI, MartinSanchez F, Pelegrin P (2016) Macrophage activation and polarization modify P2X7 receptor secretome influencing the inflammatory process. Sci Rep 6:22586. https://doi.org/10.1038/srep22586

199. Csoka B, Nemeth ZH, Toro G, Idzko M, Zech A, Koscso B, Spolarics Z, Antonioli L, Cseri K, Erdelyi K, Pacher P, Hasko G (2015) Extracellular ATP protects against sepsis through macrophage $\mathrm{P} 2 \mathrm{X} 7$ purinergic receptors by enhancing intracellular bacterial killing. FASEB J 29(9):3626-3637. https://doi.org/10.1096/ fj. $15-272450$

200. Wareham KJ, Seward EP (2016) P2X7 receptors induce degranulation in human mast cells. Purinergic Signal 12(2):235-246. https://doi.org/10.1007/s11302-016-9497-4

201. Kawamura H, Aswad F, Minagawa M, Govindarajan S, Dennert G (2006) P2X7 receptors regulate NKT cells in autoimmune hepatitis. J Immunol 176(4):2152-2160

202. Pupovac A, Foster CM, Sluyter R (2013) Human P2X7 receptor activation induces the rapid shedding of CXCL16. Biochem Biophys Res Commun 432(4):626-631. https://doi.org/10.1016/ j.bbrc.2013.01.134

203. Pupovac A, Geraghty NJ, Watson D, Sluyter R (2015) Activation of the P2X7 receptor induces the rapid shedding of $\mathrm{CD} 23$ from human and murine B cells. Immunol Cell Biol 93(1):77-85. https://doi.org/10.1038/icb.2014.69

204. Huang SW, Walker C, Pennock J, Else K, Muller W, Daniels MJ, Pellegrini C, Brough D, Lopez-Castejon G, Cruickshank SM (2017) P2X7 receptor-dependent tuning of gut epithelial responses to infection. Immunol Cell Biol 95(2):178-188. https://doi.org/10. 1038/icb.2016.75

205. Yip L, Woehrle T, Corriden R, Hirsh M, Chen Y, Inoue Y, Ferrari V, Insel PA, Junger WG (2009) Autocrine regulation of T-cell activation by ATP release and P2X7 receptors. FASEB J 23(6): 1685-1693. https://doi.org/10.1096/fj.08-126458

206. Proietti M, Cornacchione V, Rezzonico Jost T, Romagnani A, Faliti CE, Perruzza L, Rigoni R, Radaelli E, Caprioli F, Preziuso S, Brannetti B, Thelen M, McCoy KD, Slack E, Traggiai E, Grassi F (2014)ATP-gated ionotropic P2X7 receptor controls follicular T helper cell numbers in Peyer's patches to promote host-microbiota mutualism. Immunity 41(5):789-801. https://doi.org/10.1016/j. immuni.2014.10.010

207. Hubert S, Rissiek B, Klages K, Huehn J, Sparwasser T, Haag F, Koch-Nolte F, Boyer O, Seman M, Adriouch S (2010) Extracellular NAD+ shapes the Foxp3+ regulatory T cell compartment through the ART2-P2X7 pathway. J Exp Med 207(12): 2561-2568. https://doi.org/10.1084/jem.20091154

208. Wilhelm K, Ganesan J, Muller T, Durr C, Grimm M, Beilhack A, Krempl CD, Sorichter S, Gerlach UV, Juttner E, Zerweck A, Gartner F, Pellegatti P, Di Virgilio F, Ferrari D, Kambham N, Fisch P, Finke J, Idzko M, Zeiser R (2010)Graft-versus-host disease is enhanced by extracellular ATP activating P2X7R. Nat Med 16(12):1434-1438. https://doi.org/10.1038/nm.2242

209. Mishra A, Guo Y, Zhang L, More S, Weng T, Chintagari NR, Huang C, Liang Y, Pushparaj S, Gou D, Breshears M, Liu L (2016) A critical role for P2X7 receptor-induced VCAM-1 shedding and neutrophil infiltration during acute lung injury. JImmunol

210. Semenova S, Shatrova A, Vassilieva I, Shamatova M, Pugovkina N, Negulyaev Y (2020)Adenosine-5'-triphosphate suppresses proliferation and migration capacity of human endometrial stem cells.
J Cell Mol Med 24(8):4580-4588. https://doi.org/10.1111/jcmm. 15115

211. Wang J, Liu S, Nie Y, Wu B, Wu Q, Song M, Tang M, Xiao L, Xu P, Tan X, Zhang L, Li G, Liang S, Zhang C (2015) Activation of P2X7 receptors decreases the proliferation of murine luteal cells. Reprod Fertil Dev 27(8):1262-1271. https://doi.org/10.1071/ rd14381

212. Wang CM, Chang YY, Sun SH (2003) Activation of P2X7 purinoceptor-stimulated TGF-beta $1 \mathrm{mRNA}$ expression involves $\mathrm{PKC}$ MAPK signalling pathway in a rat brain-derived type-2 astrocyte cell line, RBA-2. Cell Signal 15(12):1129-1137. https:// doi.org/10.1016/s0898-6568(03)00112-8

213. Qu LP, Xue H, Yuan P, Zhou L, Yao T, Huang Y, Lu LM (2009) Adenosine 5'-triphosphate stimulates the increase of TGF-beta1 in rat mesangial cells under high-glucose conditions via reactive oxygen species and ERK1/2. Acta Pharmacol Sin 30(12):16011606. https://doi.org/10.1038/aps.2009.155

214. Fan X, Ma W, Zhang Y, Zhang L (2020) P2X7 receptor (P2X7R) of microglia mediates neuroinflammation by regulating (NOD)like receptor protein 3 (NLRP3)inflammasome-dependent inflammation after spinal cord injury. Med Sci Monit 26:e925491. https://doi.org/10.12659/msm.925491

215. Wu H, Jiang M, Liu Q, Wen F, Nie Y (2020) lncRNA uc.48+ regulates immune and inflammatory reactions mediated by the P2X(7) receptor in type 2 diabetic mice. Exp Ther Med 20(6): 230. https://doi.org/10.3892/etm.2020.9360

216. Wang W, Hu D, Feng Y, Wu C, Song Y, Liu W, Li A, Wang Y, Chen K, Tian M, Xiao F, Zhang Q, Chen W, Pan P, Wan P, Liu Y, Lan H, Wu K, Wu J (2020) Paxillin mediates ATP-induced activation of P2X7 receptor and NLRP3 inflammasome. BMC Biol 18(1):182. https://doi.org/10.1186/s12915-020-00918-w

217. Zhang C, Qin J, Zhang S, Zhang N, Tan B, Siwko S, Zhang Y, Wang Q, Chen J, Qian M, Liu M, Du B (2020) ADP/P2Y(1) aggravates inflammatory bowel disease through ERK5-mediated NLRP3 inflammasome activation. Mucosal Immunol 13(6):931945. https://doi.org/10.1038/s41385-020-0307-5

218. Alarcón-Vila C, Baroja-Mazo A, de Torre-Minguela C, Martínez CM, Martínez-García JJ, Martínez-Banaclocha H, GarcíaPalenciano C, Pelegrin P (2020) CD14 release induced by P2X7 receptor restricts inflammation and increases survival during sepsis. Elife 9. https://doi.org/10.7554/eLife.60849

219. Jiang M, Cui BW, Wu YL, Zhang Y, Shang Y, Liu J, Yang HX, Qiao CY, Zhan ZY, Ye H, Jin Q, Nan JX, Lian LH (2020) P2X7R orchestrates the progression of murine hepatic fibrosis by making a feedback loop from macrophage to hepatic stellate cells. Toxicol Lett 333:22-32. https://doi.org/10.1016/j.toxlet.2020.07.023

220. Xu SL, Lin Y, Liu W, Zhu XZ, Liu D, Tong ML, Liu LL, Lin LR (2020) The P2X7 receptor mediates NLRP3-dependent IL-1 $\beta$ secretion and promotes phagocytosis in the macrophage response to Treponema pallidum. Int Immunopharmacol 82:106344. https:// doi.org/10.1016/j.intimp.2020.106344

221. Kahlenberg JM, Carmona-Rivera C, Smith CK, Kaplan MJ (2013) Neutrophil extracellular trap-associated protein activation of the NLRP3 inflammasome is enhanced in lupus macrophages. J Immunol 190(3):1217-1226. https://doi.org/10.4049/jimmunol. 1202388

222. Pelegrin P, Surprenant A (2006)Pannexin-1 mediates large pore formation and interleukin-1 beta release by the ATP-gated P2X7 receptor. EMBO J 25(21):5071-5082. https://doi.org/10.1038/sj. emboj. 7601378

223. Suh BC, Kim JS, Namgung U, Ha H, Kim KT (2001) P2X7 nucleotide receptor mediation of membrane pore formation and superoxide generation in human promyelocytes and neutrophils. $\mathrm{J}$ Immunol 166(11):6754-6763. https://doi.org/10.4049/jimmunol. 166.11 .6754 
224. Tsukimoto M, Maehata M, Harada H, Ikari A, Takagi K, Degawa $\mathrm{M}$ (2006) P2X7 receptor-dependent cell death is modulated during murine $\mathrm{T}$ cell maturation and mediated by dual signaling pathways. J Immunol 177(5):2842-2850

225. Aswad F, Dennert G (2006) P2X7 receptor expression levels determine lethal effects of a purine based danger signal in T lymphocytes. Cell Immunol 243(1):58-65. https://doi.org/10.1016/j. cellimm.2006.12.003

226. Scheuplein F, Schwarz N, Adriouch S, Krebs C, Bannas P, Rissiek B, Seman M, Haag F, Koch-Nolte F (2009) NAD+ and ATP released from injured cells induce P2X7-dependent shedding of CD62L and externalization of phosphatidylserine by murine $\mathrm{T}$ cells. J Immunol 182(5):2898-2908. https://doi.org/10.4049/ jimmunol.0801711

227. Surprenant A, Rassendren F, Kawashima E, North RA, Buell G (1996) The cytolytic P2Z receptor for extracellular ATP identified as a $\mathrm{P} 2 \mathrm{X}$ receptor (P2X7). Science 272(5262):735-738

228. Shen D, Shen X, Schwarz W, Grygorczyk R, Wang L (2020) $\mathrm{P} 2 \mathrm{Y}(13)$ and $\mathrm{P} 2 \mathrm{X}(7)$ receptors modulate mechanically induced adenosine triphosphate release from mast cells. Exp Dermatol 29(5):499-508. https://doi.org/10.1111/exd.14093

229. Nylander S, Mattsson C, Ramstrom S, Lindahl TL (2004) Synergistic action between inhibition of P2Y12/P2Y1 and $\mathrm{P} 2 \mathrm{Y} 12 /$ thrombin in ADP- and thrombin-induced human platelet activation. Br J Pharmacol 142(8):1325-1331. https://doi.org/10. 1038/sj.bjp.0705885

230. Anderson R, Theron AJ, Steel HC, Nel JG, Tintinger GR (2020)ADP-mediated upregulation of expression of CD62P on human platelets is critically dependent on co-activation of $\mathrm{P} 2 \mathrm{Y} 1$ and P2Y12 receptors. Pharmaceuticals (Basel) 13(12). https://doi. org/10.3390/ph13120420

231. Muller T, Fay S, Vieira RP, Karmouty-Quintana H, Cicko S, Ayata K, Zissel G, Goldmann T, Lungarella G, Ferrari D, Di Virgilio F, Robaye B, Boeynaems JM, Blackburn MR, Idzko M (2017) The purinergic receptor subtype P2Y2 mediates chemotaxis of neutrophils and fibroblasts in fibrotic lung disease. Oncotarget. https://doi.org/10.18632/oncotarget.16414

232. Muller T, Robaye B, Vieira RP, Ferrari D, Grimm M, Jakob T, Martin SF, Di Virgilio F, Boeynaems JM, Virchow JC, Idzko M (2010) The purinergic receptor P2Y2 receptor mediates chemotaxis of dendritic cells and eosinophils in allergic lung inflammation. Allergy 65(12):1545-1553. https://doi.org/10.1111/j.13989995.2010.02426.x

233. Vanderstocken G, Bondue B, Horckmans M, Di Pietrantonio L, Robaye B, Boeynaems JM, Communi D (2010) P2Y2 receptor regulates VCAM-1 membrane and soluble forms and eosinophil accumulation during lung inflammation. J Immunol 185(6):3702_ 3707. https://doi.org/10.4049/jimmunol.0903908

234. de la Rosa G, Gómez AI, Baños MC, Pelegrín P (2020) Signaling through purinergic receptor $\mathrm{P} 2 \mathrm{Y}(2)$ enhances macrophage IL-1 $\beta$ production. Int J Mol Sci 21(13). https://doi.org/10.3390/ ijms 21134686

235. Thorstenberg ML, Martins MDA, Figliuolo V, Silva CLM, Savio LEB, Coutinho-Silva R (2020) P2Y(2) Receptor induces L. amazonensis infection control in a mechanism dependent on caspase-1 activation and IL-1 $\beta$ secretion. Mediat Inflamm 2020: 2545682. https://doi.org/10.1155/2020/2545682

236. Ualiyeva S, Hallen N, Kanaoka Y, Ledderose C, Matsumoto I, Junger WG, Barrett NA, Bankova LG (2020) Airway brush cells generate cysteinyl leukotrienes through the ATP sensor P2Y2. Sci Immunol 5(43). https://doi.org/10.1126/sciimmunol.aax7224

237. Ohsawa K, Irino $\mathrm{Y}$, Nakamura $\mathrm{Y}$, Akazawa $\mathrm{C}$, Inoue $\mathrm{K}$, Kohsaka $\mathrm{S}$ (2007) Involvement of P2X4 and P2Y12 receptors in ATPinduced microglial chemotaxis. Glia 55(6):604-616. https://doi. org/10.1002/glia.20489
238. Irino Y, Nakamura Y, Inoue K, Kohsaka S, Ohsawa K (2008) Akt activation is involved in $\mathrm{P} 2 \mathrm{Y} 12$ receptor-mediated chemotaxis of microglia. J Neurosci Res 86(7):1511-1519. https://doi.org/10. 1002/jnr.21610

239. Sil P, Hayes CP, Reaves BJ, Breen P, Quinn S, Sokolove J, Rada B (2017) P2Y6 receptor antagonist MRS2578 inhibits neutrophil activation and aggregated neutrophil extracellular trap formation induced by gout-associated monosodium urate crystals. J Immunol 198(1):428-442. https://doi.org/10.4049/jimmunol. 1600766

240. Uratsuji H, Tada Y, Kawashima T, Kamata M, Hau CS, Asano Y, Sugaya M, Kadono T, Asahina A, Sato S, Tamaki K (2012) P2Y6 receptor signaling pathway mediates inflammatory responses induced by monosodium urate crystals. J Immunol 188(1):436-444. https://doi.org/10.4049/jimmunol.1003746

241. Kimura T, Kobayashi S, Hanihara-Tatsuzawa F, Sayama A, MaruYama T, Muta T (2014) Responses of macrophages to the danger signals released from necrotic cells. Int Immunol 26(12): 697-704. https://doi.org/10.1093/intimm/dxu080

242. Inoue K (2007) UDP facilitates microglial phagocytosis through P2Y6 receptors. Cell Adhes Migr 1(3):131-132

243. Morioka N, Tokuhara M, Harano S, Nakamura Y, HisaokaNakashima K, Nakata Y (2013) The activation of P2Y6 receptor in cultured spinal microglia induces the production of CCL2 through the MAP kinases-NF-kappaB pathway. Neuropharmacology 75:116-125. https://doi.org/10.1016/j. neuropharm.2013.07.017

244. Xu Y, Hu W, Liu Y, Xu P, Li Z, Wu R, Shi X, Tang Y (2016) $\mathrm{P} 2 \mathrm{Y} 6$ receptor-mediated microglial phagocytosis in radiationinduced brain injury. Mol Neurobiol 53(6):3552-3564. https:// doi.org/10.1007/s12035-015-9282-3

245. Zhu J, Wang Z, Zhang N, Ma J, Xu SL, Wang Y, Shen Y, Li YH (2016) Protein interacting C-kinase 1 modulates surface expression of $\mathrm{P} 2 \mathrm{Y} 6$ purinoreceptor, actin polymerization and phagocytosis in microglia. Neurochem Res 41(4):795-803. https://doi.org/ 10.1007/s11064-015-1754-3

246. Nakano M, Ito K, Yuno T, Soma N, Aburakawa S, Kasai K, Nakamura T, Takami H (2017)UDP/P2Y6 receptor signaling regulates IgE-dependent degranulation in human basophils. Allergol Int. https://doi.org/10.1016/j.alit.2017.02.014

247. Shin A, Toy T, Rothenfusser S, Robson N, Vorac J, Dauer M, Stuplich M, Endres S, Cebon J, Maraskovsky E, Schnurr M (2008) P2Y receptor signaling regulates phenotype and IFNalpha secretion of human plasmacytoid dendritic cells. Blood 111(6):3062-3069. https://doi.org/10.1182/blood-2007-02071910

248. Khine AA, Del Sorbo L, Vaschetto R, Voglis S, Tullis E, Slutsky AS, Downey GP, Zhang H (2006) Human neutrophil peptides induce interleukin-8 production through the P2Y6 signaling pathway. Blood 107(7):2936-2942. https://doi.org/10.1182/blood2005-06-2314

249. Grbic DM, Degagne E, Larrivee JF, Bilodeau MS, Vinette V, Arguin G, Stankova J, Gendron FP (2012) P2Y6 receptor contributes to neutrophil recruitment to inflamed intestinal mucosa by increasing $\mathrm{CXC}$ chemokine ligand 8 expression in an AP-1dependent manner in epithelial cells. Inflamm Bowel Dis 18(8): 1456-1469. https://doi.org/10.1002/ibd.21931

250. Li R, Tan B, Yan Y, Ma X, Zhang N, Zhang Z, Liu M, Qian M, Du B (2014) Extracellular UDP and P2Y6 function as a danger signal to protect mice from vesicular stomatitis virus infection through an increase in IFN-beta production. J Immunol 193(9): 4515-4526. https://doi.org/10.4049/jimmunol.1301930

251. Li Z, He C, Zhang J, Zhang H, Wei H, Wu S, Jiang W (2020) P2Y(6) Deficiency enhances dendritic cell-mediatedTh1/Th17 differentiation and aggravates experimental autoimmune 
encephalomyelitis. J Immunol 205(2):387-397. https://doi.org/10. 4049/jimmunol.1900916

252. Wen RX, Shen H, Huang SX, Wang LP, Li ZW, Peng P, Mamtilahun M, Tang YH, Shen FX, Tian HL, Yang GY, Zhang ZJ (2020) P2Y6 receptor inhibition aggravates ischemic brain injury by reducing microglial phagocytosis. CNS Neurosci Ther 26(4):416-429. https://doi.org/10.1111/cns.13296

253. Vaughan KR, Stokes L, Prince LR, Marriott HM, Meis S, Kassack MU, Bingle CD, Sabroe I, Surprenant A, Whyte MK (2007) Inhibition of neutrophil apoptosis by ATP is mediated by the P2Y11 receptor. J Immunol 179(12):8544-8553

254. Alkayed F, Kashimata M, Koyama N, Hayashi T, Tamura Y, Azuma Y (2012) P2Y11 purinoceptor mediates the ATPenhanced chemotactic response of rat neutrophils. J Pharmacol Sci 120(4):288-295

255. van der Weyden L, Conigrave AD, Morris MB (2000) Signal transduction and white cell maturation via extracellular ATP and the P2Y11 receptor. Immunol Cell Biol 78(4):369-374. https:// doi.org/10.1046/j.1440-1711.2000.00918.x

256. Wilkin F, Duhant X, Bruyns C, Suarez-Huerta N, Boeynaems JM, Robaye B (2001) The P2Y11 receptor mediates the ATP-induced maturation of human monocyte-derived dendritic cells. J Immunol 166(12):7172-7177

257. Schnurr M, Toy T, Stoitzner P, Cameron P, Shin A, Beecroft T, Davis ID, Cebon J, Maraskovsky E (2003) ATP gradients inhibit the migratory capacity of specific human dendritic cell types: implications for P2Y11 receptor signaling. Blood 102(2):613-620. https://doi.org/10.1182/blood-2002-12-3745

258. Meis S, Hamacher A, Hongwiset D, Marzian C, Wiese M, Eckstein N, Royer HD, Communi D, Boeynaems JM, Hausmann R, Schmalzing G, Kassack MU (2010) NF546 [4,4'(carbonylbis(imino-3,1-phenylene-carbonylimino-3,1-(4-methylphenylene)-car bonylimino))-bis(1,3-xylene-alpha,alpha'-diphosphonic acid) tetrasodium salt] is a non-nucleotide P2Y11 agonist and stimulates release of interleukin- 8 from human monocytederived dendritic cells. J Pharmacol Exp Ther 332(1):238-247. https://doi.org/10.1124/jpet.109.157750

259. Sakaki H, Tsukimoto M, Harada H, Moriyama Y, Kojima S (2013) Autocrine regulation of macrophage activation via exocytosis of ATP and activation of P2Y11 receptor. PLoS One 8(4): e59778. https://doi.org/10.1371/journal.pone.0059778

260. Satonaka H, Nagata D, Takahashi M, Kiyosue A, Myojo M, Fujita D, Ishimitsu T, Nagano T, Nagai R, Hirata Y (2015) Involvement of P2Y12 receptor in vascular smooth muscle inflammatory changes via MCP-1 upregulation and monocyte adhesion. Am J Physiol Heart Circ Physiol 308(8):H853-H861. https://doi.org/10. 1152/ajpheart.00862.2013

261. Ben Addi A, Cammarata D, Conley PB, Boeynaems JM, Robaye B (2010) Role of the P2Y12 receptor in the modulation of murine dendritic cell function by ADP. J Immunol 185(10):5900-5906. https://doi.org/10.4049/jimmunol.0901799

262. Lou N, Takano T, Pei Y, Xavier AL, Goldman SA, Nedergaard M (2016) Purinergic receptor P2RY12-dependent microglial closure of the injured blood-brain barrier. Proc Natl Acad Sci U S A 113(4):1074-1079. https://doi.org/10.1073/pnas.1520398113

263. Haynes SE, Hollopeter G, Yang G, Kurpius D, Dailey ME, Gan WB, Julius D (2006) The P2Y12 receptor regulates microglial activation by extracellular nucleotides. Nat Neurosci 9(12): 1512-1519. https://doi.org/10.1038/nn1805

264. Moore CS, Ase AR, Kinsara A, Rao VT, Michell-Robinson M, Leong SY, Butovsky O, Ludwin SK, Seguela P, Bar-Or A, Antel JP (2015) P2Y12 expression and function in alternatively activated human microglia. Neurol Neuroimmunol Neuroinflamm 2(2): e80. https://doi.org/10.1212/nxi.0000000000000080

265. Tozaki-Saitoh H, Miyata H, Yamashita T, Matsushita K, Tsuda M, Inoue K (2017) P2Y12 receptors in primary microglia activate nuclear factor of activated T-cell signaling to induce C-C chemokine 3 expression. J Neurochem 141(1):100-110. https://doi.org/ 10.1111/jnc. 13968

266. Albayati S, Vemulapalli H, Tsygankov AY, Liverani E (2020) $\mathrm{P} 2 \mathrm{Y}(12)$ antagonism results in altered interactions between platelets and regulatory $\mathrm{T}$ cells during sepsis. J Leukoc Biol. https://doi. org/10.1002/jlb.3a0220-097r

267. Jing F, Zhang Y, Long T, He W, Qin G, Zhang D, Chen L, Zhou J (2019) P2Y12 receptor mediates microglial activation via RhoA/ ROCK pathway in the trigeminal nucleus caudalis in a mouse model of chronic migraine. J Neuroinflammation 16(1):217. https://doi.org/10.1186/s12974-019-1603-4

268. Wang L, Olivecrona G, Gotberg M, Olsson ML, Winzell MS, Erlinge D (2005) ADP acting on P2Y13 receptors is a negative feedback pathway for ATP release from human red blood cells. Circ Res 96(2):189-196. https://doi.org/10.1161/01.res. 0000153670.07559.e4

269. Arase T, Uchida H, Kajitani T, Ono M, Tamaki K, Oda H, Nishikawa S, Kagami M, Nagashima T, Masuda H, Asada H, Yoshimura Y, Maruyama T (2009) The UDP-glucose receptor P2RY14 triggers innate mucosal immunity in the female reproductive tract by inducing IL-8. J Immunol 182(11):7074-7084. https://doi.org/10.4049/jimmunol.0900001

270. Barrett MO, Sesma JI, Ball CB, Jayasekara PS, Jacobson KA, Lazarowski ER, Harden TK (2013) A selective high-affinity antagonist of the P2Y14 receptor inhibits UDP-glucose-stimulated chemotaxis of human neutrophils. Mol Pharmacol 84(1):41-49. https://doi.org/10.1124/mol.113.085654

271. Li H, Jiang W, Ye S, Zhou M, Liu C, Yang X, Hao K, Hu Q (2020) P2Y(14) receptor has a critical role in acute gouty arthritis by regulating pyroptosis of macrophages. Cell Death Dis 11(5): 394. https://doi.org/10.1038/s41419-020-2609-7

272. Kaunitz JD, Yamaguchi DT (2008) TNAP, TrAP, ecto-purinergic signaling, and bone remodeling. J Cell Biochem 105(3):655-662. https://doi.org/10.1002/jcb.21885

273. Burnstock G, Arnett TR, Orriss IR (2013) Purinergic signalling in the musculoskeletal system. Purinergic Signal 9(4):541-572. https://doi.org/10.1007/s11302-013-9381-4

274. Sebastián-Serrano Á, de Diego-García L, Martínez-Frailes C, Ávila J, Zimmermann H, Millán JL, Miras-Portugal MT, DíazHernández M (2015)Tissue-nonspecific alkaline phosphatase regulates purinergic transmission in the central nervous system during development and disease. Comput Struct Biotechnol J 13:95100. https://doi.org/10.1016/j.csbj.2014.12.004

275. Zimmermann $\mathrm{H}$ (2021) History of ectonucleotidases and their role in purinergic signaling. Biochem Pharmacol 187:114322. https:// doi.org/10.1016/j.bcp.2020.114322

276. Jacobson KA, Muller CE (2016) Medicinal chemistry of adenosine, P2Y and P2X receptors. Neuropharmacology 104:31-49. https://doi.org/10.1016/j.neuropharm.2015.12.001

277. North RA (2016) P2X receptors. Philos Trans R Soc Lond Ser B Biol Sci 371(1700). https://doi.org/10.1098/rstb.2015.0427

278. Coddou C, Stojilkovic SS, Huidobro-Toro JP (2011) Allosteric modulation of ATP-gated P2X receptor channels. Rev Neurosci 22(3):335-354. https://doi.org/10.1515/rns.2011.014

279. Coddou C, Yan Z, Obsil T, Huidobro-Toro JP, Stojilkovic SS (2011) Activation and regulation of purinergic P2X receptor channels. Pharmacol Rev 63(3):641-683. https://doi.org/10.1124/pr. 110.003129

280. Sanabria P, Ross E, Ramirez E, Colon K, Hernandez M, Maldonado HM, Silva WI, Jimenez-Rivera CA, Gonzalez FA (2008) P2Y2 receptor desensitization on single endothelial cells. Endothelium 15(1):43-51. https://doi.org/10.1080/ 10623320802092294

281. Schulte G, Fredholm BB (2000) Human adenosine A(1), A(2A), $\mathrm{A}(2 \mathrm{~B})$, and $\mathrm{A}(3)$ receptors expressed in Chinese hamster ovary 
cells all mediate the phosphorylation of extracellular-regulated kinase 1/2. Mol Pharmacol 58(3):477-482

282. Klaasse EC, Ijzerman AP, de Grip WJ, Beukers MW (2008) Internalization and desensitization of adenosine receptors. Purinergic Signal 4(1):21-37. https://doi.org/10.1007/s11302007-9086-7

283. North RA (2002) Molecular physiology of P2X receptors. Physiol Rev 82(4):1013-1067. https://doi.org/10.1152/physrev.00015. 2002

284. Illes P, Müller CE, Jacobson KA, Grutter T, Nicke A, Fountain SJ, Kennedy C, Schmalzing G, Jarvis MF, Stojilkovic SS, King BF, Di Virgilio F (2021) Update of P2X receptor properties and their pharmacology: IUPHAR review 30. Br J Pharmacol 178(3):489514. https://doi.org/10.1111/bph.15299

285. Fischer W, Urban N, Immig K, Franke H, Schaefer M (2014) Natural compounds with $\mathrm{P} 2 \mathrm{X} 7$ receptor-modulating properties. Purinergic Signal 10(2):313-326. https://doi.org/10.1007/ s11302-013-9392-1

286. Roth-Cross JK, Bender SJ, Weiss SR (2008) Murine coronavirus mouse hepatitis virus is recognized by MDA5 and induces type I interferon in brain macrophages/microglia. J Virol 82(20):9829 9838. https://doi.org/10.1128/jvi.01199-08

287. Swayne LA, Johnstone SR, Ng CS, Sanchez-Arias JC, Good ME, Penuela S, Lohman AW, Wolpe AG, Laubach VE, Koval M, Isakson BE (2020) Consideration of pannexin 1 channels in COVID-19 pathology and treatment. Am J Phys Lung Cell Mol Phys 319(1):L121-1125. https://doi.org/10.1152/ajplung.00146. 2020

288. Agier J, Brzezińska-Błaszczyk E, Żelechowska P, Wiktorska M, Pietrzak J, Różalska S (2018) Cathelicidin LL-37 affects surface and intracellular toll-like receptor expression in tissue mast cells. J Immunol Res 2018:7357162. https://doi.org/10.1155/2018/ 7357162

289. Lohman AW, Leskov IL, Butcher JT, Johnstone SR, Stokes TA, Begandt D, DeLalio LJ, Best AK, Penuela S, Leitinger N, Ravichandran KS, Stokes KY, Isakson BE (2015) Pannexin 1 channels regulate leukocyte emigration through the venous endothelium during acute inflammation. Nat Commun 6:7965. https:// doi.org/10.1038/ncomms8965

290. Idzko M, Ferrari D, Eltzschig HK (2014) Nucleotide signalling during inflammation. Nature 509(7500):310-317

291. Di Virgilio F, Sarti AC, Coutinho-Silva R (2020) Purinergic signaling, DAMPs, and inflammation. Am J Phys Cell Phys 318(5): C832-C835. https://doi.org/10.1152/ajpcell.00053.2020

292. Venereau E, Ceriotti C, Bianchi ME (2015) DAMPs from cell death to new life. Front Immunol 6:422. https://doi.org/10.3389/ fimmu.2015.00422

293. McGonagle D, O'Donnell JS, Sharif K, Emery P, Bridgewood C (2020) Immune mechanisms of pulmonary intravascular coagulopathy in COVID-19 pneumonia. Lancet Rheumatol 2(7):e437e445. https://doi.org/10.1016/s2665-9913(20)30121-1

294. Jacobson KA, Delicado EG, Gachet C, Kennedy C, von Kügelgen I, Li B, Miras-Portugal MT, Novak I, Schöneberg T, Perez-Sen R, Thor D, Wu B, Yang Z, Müller CE (2020) Update of P2Y receptor pharmacology: IUPHAR Review 27. Br J Pharmacol 177(11): 2413-2433. https://doi.org/10.1111/bph.15005

295. Eckle T, Fullbier L, Wehrmann M, Khoury J, Mittelbronn M, Ibla J, Rosenberger P, Eltzschig HK (2007) Identification of ectonucleotidases CD39 and CD73 in innate protection during acute lung injury. J Immunol 178(12):8127-8137

296. Zhao R, Qiao J, Zhang X, Zhao Y, Meng X, Sun D, Peng X (2019)Toll-like receptor-mediated activation of CD39 internalization in BMDCs leads to extracellular ATP accumulation and facilitates P2X7 receptor activation. Front Immunol 10:2524. https://doi.org/10.3389/fimmu.2019.02524
297. Burnstock G (2016) P2X ion channel receptors and inflammation. Purinergic Signal 12(1):59-67. https://doi.org/10.1007/s11302015-9493-0

298. Di Virgilio F, Tang Y, Sarti AC, Rossato M (2020) A rationale for targeting the $\mathrm{P} 2 \mathrm{X} 7$ receptor in coronavirus disease 19 (Covid-19). Br J Pharmacol. https://doi.org/10.1111/bph.15138

299. Savio LEB, de Andrade MP, da Silva CG, Coutinho-Silva R (2018) The P2X7 receptor in inflammatory diseases: angel or demon? Front Pharmacol 9:52. https://doi.org/10.3389/fphar. 2018.00052

300. Flores RV, Hernandez-Perez MG, Aquino E, Garrad RC, Weisman GA, Gonzalez FA (2005)Agonist-induced phosphorylation and desensitization of the P2Y2 nucleotide receptor. Mol Cell Biochem 280(1-2):35-45. https://doi.org/10.1007/s11010005-8050-5

301. Sromek SM, Harden TK (1998)Agonist-induced internalization of the P2Y2 receptor. Mol Pharmacol 54(3):485-494

302. Hotchkiss RS, Monneret G, Payen D (2013)Sepsis-induced immunosuppression: from cellular dysfunctions to immunotherapy. Nat Rev Immunol 13(12):862-874. https://doi.org/10.1038/ nri3552

303. Hotchkiss RS, Monneret G, Payen D (2013) Immunosuppression in sepsis: a novel understanding of the disorder and a new therapeutic approach. Lancet Infect Dis 13(3):260-268. https://doi.org/ 10.1016/s1473-3099(13)70001-x

304. Ward NS, Casserly B, Ayala A (2008) The compensatory antiinflammatory response syndrome (CARS) in critically ill patients. Clin Chest Med 29(4):617-625, viii. https://doi.org/10.1016/j. ccm.2008.06.010

305. Bone RC (1996) Sir Isaac Newton, sepsis, SIRS, and CARS. Crit Care Med 24(7):1125-1128. https://doi.org/10.1097/00003246199607000-00010

306. Musuuza JS, Watson L, Parmasad V, Putman-Buehler N, Christensen L, Safdar N (2021) Prevalence and outcomes of coinfection and superinfection with SARS-CoV-2 and other pathogens: a systematic review and meta-analysis. PLoS One 16(5): e0251170. https://doi.org/10.1371/journal.pone.0251170

307. Hori S, Carvalho TL, Demengeot J (2002) CD25+CD4+ regulatory $\mathrm{T}$ cells suppress CD4+ T cell-mediated pulmonary hyperinflammation driven by Pneumocystis carinii in immunodeficient mice. Eur J Immunol 32(5):1282-1291.

308. Chen G, Wu D, Guo W, Cao Y, Huang D, Wang H, Wang T, Zhang X, Chen H, Yu H, Zhang X, Zhang M, Wu S, Song J, Chen T, Han M, Li S, Luo X, Zhao J, Ning Q (2020) Clinical and immunological features of severe and moderate coronavirus disease 2019. J Clin Invest 130(5):2620-2629. https://doi.org/10. $1172 /$ jci137244

309. Sadeghi A, Tahmasebi S, Mahmood A, Kuznetsova M, Valizadeh H, Taghizadieh A, Nazemiyeh M, Aghebati-Maleki L, JadidiNiaragh F, Abbaspour-Aghdam S, Roshangar L, Mikaeili H, Ahmadi M (2020) Th17 and Treg cells function in SARS-CoV2 patients compared with healthy controls. J Cell Physiol. https:// doi.org/10.1002/jcp.30047

310. Wang F, Hou H, Luo Y, Tang G, Wu S, Huang M, Liu W, Zhu Y, Lin Q, Mao L, Fang M, Zhang H, Sun Z (2020) The laboratory tests and host immunity of COVID-19 patients with different severity of illness. JCI Insight 5(10). https://doi.org/10.1172/jci. insight.137799

311. Meckiff BJ, Ramírez-Suástegui C, Fajardo V, Chee SJ, Kusnadi A, Simon H, Eschweiler S, Grifoni A, Pelosi E, Weiskopf D, Sette A, Ay F, Seumois G, Ottensmeier CH, Vijayanand P (2020) Imbalance of regulatory and cytotoxic SARS-CoV-2-reactive CD4(+) T cells in COVID-19. Cell. https://doi.org/10.1016/j. cell.2020.10.001

312. Wu X, Ren J, Chen G, Wu L, Song X, Li G, Deng Y, Wang G, Gu G, Li J (2017) Systemic blockade of P2X7 receptor protects 
against sepsis-induced intestinal barrier disruption. Sci Rep 7(1): 4364. https://doi.org/10.1038/s41598-017-04231-5

313. Wang S, Zhao J, Wang H, Liang Y, Yang N, Huang Y (2015) Blockage of P2X7 attenuates acute lung injury in mice by inhibiting NLRP3 inflammasome. Int Immunopharmacol 27(1): 38-45. https://doi.org/10.1016/j.intimp.2015.04.035

314. Galam L, Rajan A, Failla A, Soundararajan R, Lockey RF, Kolliputi N (2016) Deletion of P2X7 attenuates hyperoxiainduced acute lung injury via inflammasome suppression. Am J Phys Lung Cell Mol Phys 310(6):L572-L581. https://doi.org/10. 1152/ajplung.00417.2015

315. Pacheco PAF, Faria RX (2021) The potential involvement of P2X7 receptor in COVID-19 pathogenesis: a new therapeutic target? Scand J Immunol 93(2):e12960. https://doi.org/10.1111/sji. 12960

316. Ribeiro DE, Oliveira-Giacomelli Á, Glaser T, Arnaud-Sampaio VF, Andrejew R, Dieckmann L, Baranova J, Lameu C, Ratajczak MZ, Ulrich H (2021) Hyperactivation of P2X7 receptors as a culprit of COVID-19 neuropathology. Mol Psychiatry 26(4):1044-1059. https://doi.org/10.1038/s41380-020-00965-3

317. Wang HL, Xing YQ, Xu YX, Rong F, Lei WF, Zhang WH (2013) The protective effect of lidocaine on septic rats via the inhibition of high mobility group box 1 expression and NF- $\mathrm{kB}$ activation. Mediat Inflamm 2013:570370. https://doi.org/10.1155/2013/ 570370

318. Liu J, Zhang H, Qi Z, Zheng X (2014) Lidocaine protects against renal and hepatic dysfunction in septic rats via downregulation of Toll-like receptor 4. Mol Med Rep 9(1):118-124. https://doi.org/ 10.3892/mmr.2013.1799

319. Gallos G, Jones DR, Nasr SH, Emala CW, Lee HT (2004) Local anesthetics reduce mortality and protect against renal and hepatic dysfunction in murine septic peritonitis. Anesthesiology 101(4): 902-911. https://doi.org/10.1097/00000542-200410000-00015

320. Berger C, Rossaint J, Van Aken H, Westphal M, Hahnenkamp K, Zarbock A (2014) Lidocaine reduces neutrophil recruitment by abolishing chemokine-induced arrest and transendothelial migration in septic patients. J Immunol 192(1):367-376. https://doi.org/ 10.4049/jimmunol.1301363

321. Barnes BJ, Adrover JM, Baxter-Stoltzfus A, Borczuk A, CoolsLartigue J, Crawford JM, Daßler-Plenker J, Guerci P, Huynh C, Knight JS, Loda M, Looney MR, McAllister F, Rayes R, Renaud S, Rousseau S, Salvatore S, Schwartz RE, Spicer JD et al (2020) Targeting potential drivers of COVID-19: neutrophil extracellular traps. J Exp Med 217(6). https://doi.org/10.1084/jem.20200652

322. Narasaraju T, Tang BM, Herrmann M, Muller S, Chow VTK, Radic M (2020) Neutrophilia and NETopathy as key pathologic drivers of progressive lung impairment in patients with COVID19. Front Pharmacol 11:870. https://doi.org/10.3389/fphar.2020. 00870

323. Middleton EA, He XY, Denorme F, Campbell RA, Ng D, Salvatore SP, Mostyka M, Baxter-Stoltzfus A, Borczuk AC, Loda M, Cody MJ, Manne BK, Portier I, Harris ES, Petrey AC, Beswick EJ, Caulin AF, Iovino A, Abegglen LM et al (2020) Neutrophil extracellular traps contribute to immunothrombosis in COVID-19 acute respiratory distress syndrome. Blood 136(10):1169-1179. https://doi.org/10.1182/blood.2020007008

324. Tomar B, Anders HJ, Desai J, Mulay SR (2020) Neutrophils and neutrophil extracellular traps drive necroinflammation in COVID19. Cells 9(6). https://doi.org/10.3390/cells9061383

325. Li H, Li C, Zhang H, Zhang L, Cheng R, Li M, Guo Y, Zhang Z, Lu Z, Zhuang Y, Yan M, Gu Y, Feng X, Liang J, Yu X, Wang H, Yao Z (2016) Effects of lidocaine on regulatory $\mathrm{T}$ cells in atopic dermatitis. J Allergy Clin Immunol 137(2):613-617.e615. https:// doi.org/10.1016/j.jaci.2015.07.039

326. Van Der Wal S, Vaneker M, Steegers M, Van Berkum B, Kox M, Van Der Laak J, Van Der Hoeven J, Vissers K, Scheffer GJ (2015)
Lidocaine increases the anti-inflammatory cytokine IL-10 following mechanical ventilation in healthy mice. Acta Anaesthesiol Scand 59(1):47-55. https://doi.org/10.1111/aas.12417

327. Garutti I, Rancan L, Simón C, Cusati G, Sanchez-Pedrosa G, Moraga F, Olmedilla L, Lopez-Gil MT, Vara E (2014) Intravenous lidocaine decreases tumor necrosis factor alpha expression both locally and systemically in pigs undergoing lung resection surgery. Anesth Analg 119(4):815-828. https://doi.org/ 10.1213/ane. 0000000000000360

328. Hermanns H, Hollmann MW, Stevens MF, Lirk P, Brandenburger T, Piegeler T, Werdehausen R (2019) Molecular mechanisms of action of systemic lidocaine in acute and chronic pain: a narrative review. Br J Anaesth 123(3):335-349. https://doi.org/10.1016/j. bja.2019.06.014

329. Weinberg L, Peake B, Tan C, Nikfarjam M (2015) Pharmacokinetics and pharmacodynamics of lignocaine: a review. World J Anesthesiol 4(2):17-29. https://doi.org/10.5313/ wja.v4.i2.17

330. Montnach J, Lorenzini M, Lesage A, Simon I, Nicolas S, Moreau E, Marionneau C, Baró I, De Waard M, Loussouarn G (2021) Computer modeling of whole-cell voltage-clamp analyses to delineate guidelines for good practice of manual and automated patch-clamp. Sci Rep 11(1):3282. https://doi.org/10.1038/ s41598-021-82077-8

331. Wang Y, Jones PJ, Batts TW, Landry V, Patel MK, Brown ML (2009)Ligand-based design and synthesis of novel sodium channel blockers from a combined phenytoin-lidocaine pharmacophore. Bioorg Med Chem 17(19):7064-7072. https:// doi.org/10.1016/j.bmc.2008.10.031

332. Cheng KI, Lai CS, Wang FY, Wang HC, Chang LL, Ho ST, Tsai HP, Kwan AL (2011) Intrathecal lidocaine pretreatment attenuates immediate neuropathic pain by modulating Nav1.3 expression and decreasing spinal microglial activation. BMC Neurol 11:71. https://doi.org/10.1186/1471-2377-11-71

333. Gingrich KJ, Wagner LE 2nd (2016)Fast-onset lidocaine block of rat NaV1.4 channels suggests involvement of a second highaffinity open state. Biochim Biophys Acta 1858(6):1175-1188. https://doi.org/10.1016/j.bbamem.2016.02.033

334. Elajnaf T, Baptista-Hon DT, Hales TG (2018) Potent inactivationdependent inhibition of adult and neonatal NaV1.5 channels by lidocaine and levobupivacaine. Anesth Analg 127(3):650-660. https://doi.org/10.1213/ane.0000000000003597

335. Sheets PL, Jarecki BW, Cummins TR (2011) Lidocaine reduces the transition to slow inactivation in $\mathrm{Na}(\mathrm{v}) 1.7$ voltage-gated sodium channels. Br J Pharmacol 164(2b):719-730. https://doi.org/10. 1111/j.1476-5381.2011.01209.x

336. Mert T, Gunes Y (2012) Antinociceptive activities of lidocaine and the nav1.8 blocker a803467 in diabetic rats. J Am Assoc Lab Anim Sci 51(5):579-585

337. Dusmez D, Cengiz B, Yumrutas O, Demir T, Oztuzcu S, Demiryurek S, Tutar E, Bayraktar R, Bulut A, Simsek H, Daglı SN, K1lic T, Bagcı C (2014) Effect of verapamil and lidocaine on TRPM and NaV1.9 gene expressions in renal ischemia-reperfusion. Transplant Proc 46(1):33-39. https://doi.org/10.1016/j. transproceed.2013.10.036

338. Wang L, Wang M, Li S, Wu H, Shen Q, Zhang S, Fang L, Liu R (2018) Nebulized lidocaine ameliorates allergic airway inflammation via downregulation of TLR2. Mol Immunol 97:94-100. https://doi.org/10.1016/j.molimm.2018.03.010

339. Nishizawa N, Shirasaki T, Nakao S, Matsuda H, Shingu K (2002) The inhibition of the N-methyl-D-aspartate receptor channel by local anesthetics in mouse CA1 pyramidal neurons. Anesth Analg 94(2):325-330, table of contents. https://doi.org/10.1097/ 00000539-200202000-00017

340. Bennett DL, Clark AJ, Huang J, Waxman SG, Dib-Hajj SD (2019) The role of voltage-gated sodium channels in pain signaling. 
Physiol Rev 99(2):1079-1151. https://doi.org/10.1152/physrev. 00052.2017

341. Kis-Toth K, Hajdu P, Bacskai I, Szilagyi O, Papp F, Szanto A, Posta E, Gogolak P, Panyi G, Rajnavolgyi E (2011)Voltage-gated sodium channel Nav1.7 maintains the membrane potential and regulates the activation and chemokine-induced migration of a monocyte-derived dendritic cell subset. J Immunol 187(3):12731280. https://doi.org/10.4049/jimmunol.1003345

342. Carrithers LM, Hulseberg P, Sandor M, Carrithers MD (2011) The human macrophage sodium channel $\mathrm{NaV} 1.5$ regulates mycobacteria processing through organelle polarization and localized calcium oscillations. FEMS Immunol Med Microbiol 63(3): 319-327. https://doi.org/10.1111/j.1574-695X.2011.00853.x

343. Black JA, Waxman SG (2012) Sodium channels and microglial function. Exp Neurol 234(2):302-315. https://doi.org/10.1016/j. expneurol.2011.09.030

344. Poffers M, Bühne N, Herzog C, Thorenz A, Chen R, Güler F, Hage A, Leffler A, Echtermeyer F (2018) Sodium channel Nav1.3 is expressed by polymorphonuclear neutrophils during mouse heart and kidney ischemia in vivo and regulates adhesion, transmigration, and chemotaxis of human and mouse neutrophils in vitro. Anesthesiology 128(6):1151-1166. https://doi.org/10. 1097/aln.0000000000002135

345. Lo WL, Donermeyer DL, Allen PM (2012) A voltage-gated sodium channel is essential for the positive selection of CD4(+) T cells. Nat Immunol 13(9):880-887. https://doi.org/10.1038/ni. 2379

346. Lee JY, Kam YL, Oh J, Kim DH, Choi JS, Choi HY, Han S, Youn I, Choo HP, Yune TY (2017) HYP-17, a novel voltage-gated sodium channel blocker, relieves inflammatory and neuropathic pain in rats. Pharmacol Biochem Behav 153:116-129. https:// doi.org/10.1016/j.pbb.2016.12.013

347. Jarvis MF, Honore P, Shieh CC, Chapman M, Joshi S, Zhang XF, Kort M, Carroll W, Marron B, Atkinson R, Thomas J, Liu D, Krambis M, Liu Y, McGaraughty S, Chu K, Roeloffs R, Zhong C, Mikusa JP et al (2007) A-803467, a potent and selective Nav1.8 sodium channel blocker, attenuates neuropathic and inflammatory pain in the rat. Proc Natl Acad Sci U S A 104(20):8520-8525. https://doi.org/10.1073/pnas.0611364104

348. Joshi SK, Honore P, Hernandez G, Schmidt R, Gomtsyan A, Scanio M, Kort M, Jarvis MF (2009) Additive antinociceptive effects of the selective Nav1.8 blocker A-803467 and selective TRPV1 antagonists in rat inflammatory and neuropathic pain models. J Pain 10(3):306-315. https://doi.org/10.1016/j.jpain. 2008.09.007

349. Bankar G, Goodchild SJ, Howard S, Nelkenbrecher K, Waldbrook M, Dourado M, Shuart NG, Lin S, Young C, Xie Z, Khakh K, Chang E, Sojo LE, Lindgren A, Chowdhury S, Decker S, Grimwood M, Andrez JC, Dehnhardt CM et al (2018) Selective $\mathrm{Na}(\mathrm{V}) 1.7$ Antagonists with long residence time show improved efficacy against inflammatory and neuropathic pain. Cell Rep 24(12):3133-3145. https://doi.org/10.1016/j.celrep. 2018.08.063

350. Sun H, Jiang J, Gong L, Li X, Yang Y, Luo Y, Guo Z, Lu R, Li H, Li J, Zhao J, Yang N, Li Y (2019)Voltage-gated sodium channel inhibitor reduces atherosclerosis by modulating monocyte/ macrophage subsets and suppressing macrophage proliferation. Biomed Pharmacother 120:109352. https://doi.org/10.1016/j. biopha.2019.109352

351. Beloeil H, Ababneh Z, Chung R, Zurakowski D, Mulkern RV, Berde CB (2006) Effects of bupivacaine and tetrodotoxin on carrageenan-induced hind paw inflammation in rats (Part 1): hyperalgesia, edema, and systemic cytokines. Anesthesiology 105(1):128-138. https://doi.org/10.1097/00000542-20060700000022
352. Beloeil H, Ji RR, Berde CB (2006) Effects of bupivacaine and tetrodotoxin on carrageenan-induced hind paw inflammation in rats (Part 2): cytokines and p38 mitogen-activated protein kinases in dorsal root ganglia and spinal cord. Anesthesiology 105(1): 139-145. https://doi.org/10.1097/00000542-200607000-00023

353. Alcántara Montero A, Sánchez Carnerero CI (2021)Voltage-gated sodium channel blockers: new perspectives in the treatment of neuropathic pain. Neurologia 36(2):169-171. https://doi.org/10. 1016/j.nrl.2020.02.004

354. Huang C, Wang Y, Li X, Ren L, Zhao J, Hu Y, Zhang L, Fan G, Xu J, Gu X, Cheng Z, Yu T, Xia J, Wei Y, Wu W, Xie X, Yin W, $\mathrm{Li} \mathrm{H}$, Liu M et al (2020) Clinical features of patients infected with 2019 novel coronavirus in Wuhan, China. Lancet 395(10223): 497-506. https://doi.org/10.1016/S0140-6736(20)30183-5

355. Dhar SK, K V, Damodar S, Gujar S, Das M (2021)IL-6 and IL-10 as predictors of disease severity in COVID-19 patients: results from meta-analysis and regression. Heliyon 7(2):e06155. https:// doi.org/10.1016/j.heliyon.2021.e06155

356. Udomsinprasert W, Jittikoon J, Sangroongruangsri S, Chaikledkaew U (2021) Circulating levels of interleukin-6 and Interleukin-10, but not tumor necrosis factor-alpha, as potential biomarkers of severity and mortality for COVID-19: systematic review with meta-analysis. J Clin Immunol 41(1):11-22. https:// doi.org/10.1007/s10875-020-00899-Z

357. Sun D, Li H, Lu XX, Xiao H, Ren J, Zhang FR, Liu ZS (2020) Clinical features of severe pediatric patients with coronavirus disease 2019 in Wuhan: a single center's observational study. World J Pediatr. https://doi.org/10.1007/s12519-020-00354-4

358. Zhou C, Qi C, Zhao J, Wang F, Zhang W, Li C, Jing J, Kang X, Chai $Z$ (2011)Interleukin-1 $\beta$ inhibits voltage-gated sodium currents in a time- and dose-dependent manner in cortical neurons. Neurochem Res 36(6):1116-1123. https://doi.org/10.1007/ s11064-011-0456-8

359. Li X, Chen W, Sheng J, Cao D, Wang W (2014)Interleukin-6 inhibits voltage-gated sodium channel activity of cultured rat spinal cord neurons. Acta Neuropsychiatr 26(3):170-177. https://doi. org/10.1017/neu.2013.49

360. Shen KF, Zhu HQ, Wei XH, Wang J, Li YY, Pang RP, Liu XG (2013)Interleukin-10 down-regulates voltage gated sodium channels in rat dorsal root ganglion neurons. Exp Neurol 247:466-475. https://doi.org/10.1016/j.expneurol.2013.01.018

361. Del Puerto A, Fronzaroli-Molinieres L, Perez-Alvarez MJ, Giraud P, Carlier E, Wandosell F, Debanne D, Garrido JJ (2015)ATP$\mathrm{P} 2 \mathrm{X} 7$ receptor modulates axon initial segment composition and function in physiological conditions and brain injury. Cereb Cortex 25(8):2282-2294. https://doi.org/10.1093/cercor/bhu035

362. Huang C, Chi XS, Li R, Hu X, Xu HX, Li JM, Zhou D (2017) Inhibition of P2X7 receptor ameliorates nuclear factor-kappa B mediated neuroinflammation induced by status epilepticus in rat hippocampus. J Mol Neurosci 63(2):173-184. https://doi.org/10. 1007/s12031-017-0968-Z

363. Liu Y, Xiao Y, Li Z (2011) P2X7 receptor positively regulates MyD88-dependent NF-KB activation. Cytokine 55(2):229-236. https://doi.org/10.1016/j.cyto.2011.05.003

364. Petrenko AB, Yamakura T, Baba H, Shimoji K (2003) The role of $\mathrm{N}$-methyl-D-aspartate(NMDA) receptors in pain: a review. Anesth Analg 97(4):1108-1116. https://doi.org/10.1213/01.ane. 0000081061.12235 .55

365. Di Loreto S, Balestrino M, Pellegrini P, Berghella AM, Del Beato T, Di Marco F, Adorno D (1997) Blockade of N-methyl-Daspartate receptor prevents hypoxic neuronal death and cytokine release. Neuroimmunomodulation 4(4):195-199. https://doi.org/ $10.1159 / 000097338$

366. Érces D, Varga G, Fazekas B, Kovács T, Tőkés T, Tiszlavicz L, Fülöp F, Vécsei L, Boros M, Kaszaki J (2012)N-methyl-Daspartate receptor antagonist therapy suppresses colon motility 
and inflammatory activation six days after the onset of experimental colitis in rats. Eur J Pharmacol 691(1-3):225-234. https://doi. org/10.1016/j.ejphar.2012.06.044

367. Liu CH, Cherng CH, Lin SL, Yeh CC, Wu CT, Tai YH, Wong CS (2011)N-methyl-D-aspartate receptor antagonist MK-801 suppresses glial pro-inflammatory cytokine expression in morphinetolerant rats. Pharmacol Biochem Behav 99(3):371-380. https:// doi.org/10.1016/j.pbb.2011.05.016

368. Simma N, Bose T, Kahlfuss S, Mankiewicz J, Lowinus T, Lühder F, Schüler T, Schraven B, Heine M, Bommhardt U (2014)NMDA-receptor antagonists block B-cell function but foster IL-10 production in BCR/CD40-activated B cells. Cell Commun Signal 12:75. https://doi.org/10.1186/s12964-0140075-5

369. Sugimoto M, Uchida I, Mashimo T (2003) Local anaesthetics have different mechanisms and sites of action at the recombinant $\mathrm{N}$-methyl-D-aspartate(NMDA) receptors. Br J Pharmacol 138(5): 876-882. https://doi.org/10.1038/sj.bjp.0705107

370. Hahnenkamp K, Durieux ME, Hahnenkamp A, Schauerte SK, Hoenemann CW, Vegh V, Theilmeier G, Hollmann MW (2006) Local anaesthetics inhibit signalling of human NMDA receptors recombinantly expressed in Xenopus laevis oocytes: role of protein kinase C. Br J Anaesth 96(1):77-87. https://doi.org/10.1093/ bja/aei271

371. Kahlfuß S, Simma N, Mankiewicz J, Bose T, Lowinus T, KleinHessling S, Sprengel R, Schraven B, Heine M, Bommhardt U (2014) Immunosuppression by N-methyl-D-aspartate receptor antagonists is mediated through inhibition of $\mathrm{Kv} 1.3$ and $\mathrm{KCa} 3.1$ channels in T cells. Mol Cell Biol 34(5):820-831. https://doi. org $/ 10.1128 / \mathrm{mcb} .01273-13$

372. Hajimohammadreza I, Probert AW, Coughenour LL, Borosky SA, Marcoux FW, Boxer PA, Wang KK (1995) A specific inhibitor of calcium/calmodulin-dependent protein kinase-II provides neuroprotection against NMDA- and hypoxia/hypoglycemiainduced cell death. J Neurosci 15(5 Pt 2):4093-4101. https://doi. org/10.1523/jneurosci.15-05-04093.1995

373. Cotrina ML, Nedergaard M (2009) Physiological and pathological functions of P2X7 receptor in the spinal cord. Purinergic Signal 5(2):223-232. https://doi.org/10.1007/s11302-009-9138-2

374. Alves LA, Bezerra RJ, Faria RX, Ferreira LG, da Silva FV (2013) Physiological roles and potential therapeutic applications of the P2X7 receptor in inflammation and pain. Molecules 18(9): 10953-10972. https://doi.org/10.3390/molecules 180910953

375. Hunter MC, Teijeira A, Halin C (2016) T cell trafficking through lymphatic vessels. Front Immunol 7:613. https://doi.org/10.3389/ fimmu.2016.00613

376. Teijeira A, Russo E, Halin C (2014) Taking the lymphatic route: dendritic cell migration to draining lymph nodes. Semin Immunopathol 36(2):261-274. https://doi.org/10.1007/s00281013-0410-8

377. Lund H, Boysen P, Åkesson CP, Lewandowska-Sabat AM, Storset AK (2016) Transient migration of large numbers of CD14(++) CD16(+) monocytes to the draining lymph node after onset of inflammation. Front Immunol 7:322. https://doi.org/10. 3389/fimmu.2016.00322

378. Louie DAP, Liao S (2019) Lymph node subcapsular sinus macrophages as the frontline of lymphatic immune defense. Front Immunol 10:347. https://doi.org/10.3389/fimmu.2019.00347

379. Hampton HR, Chtanova T (2016) The lymph node neutrophil. Semin Immunol 28(2):129-136. https://doi.org/10.1016/j.smim. 2016.03.008

380. Wang HW, Tedla N, Lloyd AR, Wakefield D, McNeil PH (1998) Mast cell activation and migration to lymph nodes during induction of an immune response in mice. J Clin Invest 102(8):16171626. https://doi.org/10.1172/jci3704
381. Shi HZ, Humbles A, Gerard C, Jin Z, Weller PF (2000) Lymph node trafficking and antigen presentation by endobronchial eosinophils. J Clin Invest 105(7):945-953. https://doi.org/10.1172/ jci8945

382. Kim S, Prout M, Ramshaw H, Lopez AF, LeGros G, Min B (2010) Cutting edge: basophils are transiently recruited into the draining lymph nodes during helminth infection via IL-3, but infectioninduced Th2 immunity can develop without basophil lymph node recruitment or IL-3. J Immunol 184(3):1143-1147. https://doi.org/ 10.4049/jimmunol.0902447

383. Tse D, Stan RV (2010) Morphological heterogeneity of endothelium. Semin Thromb Hemost 36(3):236-245. https://doi.org/10. 1055/s-0030-1253447

384. Kretsos K, Kasting GB (2005) Dermal capillary clearance: physiology and modeling. Skin Pharmacol Physiol 18(2):55-74 https://doi.org/10.1159/000083706

385. Breslin JW, Yang Y, Scallan JP, Sweat RS, Adderley SP, Murfee WL (2018) Lymphatic vessel network structure and physiology. Compr Physiol 9(1):207-299. https://doi.org/10.1002/cphy. c180015

386. Kersey TW, Van Eyk J, Lannin DR, Chua AN, Tafra L (2001) Comparison of intradermal and subcutaneous injections in lymphatic mapping. J Surg Res 96(2):255-259. https://doi.org/10. $1006 /$ jsre.2000.6075

387. Karimeddini MK (1989) Intradermal pathways. In: Spencer RP (ed) New procedures in nuclear medicine. CRC Press, Inc., Boca Raton, pp 208-211

388. Thomasy SM, Pypendop BH, Ilkiw JE, Stanley SD (2005) Pharmacokinetics of lidocaine and its active metabolite, monoethylglycinexylidide, after intravenous administration of lidocaine to awake and isoflurane-anesthetized cats. Am J Vet Res 66(7):1162-1166

389. Hatef DA, Brown SA, Lipschitz AH, Kenkel JM (2009) Efficacy of lidocaine for pain control in subcutaneous infiltration during liposuction. Aesthet Surg J 29(2):122-128. https://doi.org/10. 1016/j.asj.2009.01.014

390. Wu F, Tamhane M, Morris ME (2012) Pharmacokinetics, lymph node uptake, and mechanistic PK model of near-infrared dye-labeled bevacizumab after IV and SC administration in mice. AAPS J 14(2):252-261. https://doi.org/10.1208/s12248-012-9342-9

391. Dahlberg AM, Kaminskas LM, Smith A, Nicolazzo JA, Porter CJ, Bulitta JB, McIntosh MP (2014) The lymphatic system plays a major role in the intravenous and subcutaneous pharmacokinetics of trastuzumab in rats. Mol Pharm 11(2):496-504. https://doi.org/ 10.1021/mp400464s

392. Worley DR, Hansen RJ, Wittenburg LA, Chubb LS, Gustafson DL (2016) Docetaxel accumulates in lymphatic circulation following subcutaneous delivery compared to intravenous delivery in rats. Anticancer Res 36(10):5071-5078. https://doi.org/10. 21873/anticanres. 11076

393. Stock TC, Bloom BJ, Wei N, Ishaq S, Park W, Wang X, Gupta P, Mebus CA (2012) Efficacy and safety of CE-224,535, an antagonist of $\mathrm{P} 2 \mathrm{X} 7$ receptor, in treatment of patients with rheumatoid arthritis inadequately controlled by methotrexate. J Rheumatol 39(4):720-727. https://doi.org/10.3899/jrheum.110874

394. Keystone EC, Wang MM, Layton M, Hollis S, McInnes IB (2012) Clinical evaluation of the efficacy of the $\mathrm{P} 2 \mathrm{X} 7$ purinergic receptor antagonist AZD9056 on the signs and symptoms of rheumatoid arthritis in patients with active disease despite treatment with methotrexate or sulphasalazine. Ann Rheum Dis 71(10):1630 1635. https://doi.org/10.1136/annrheumdis-2011-143578

395. Bhattacharya A (2018) Recent advances in CNS P2X7 physiology and pharmacology: focus on neuropsychiatric disorders. Front Pharmacol 9:30. https://doi.org/10.3389/fphar.2018.00030

396. Timmers M, Ravenstijn P, Xi L, Triana-Baltzer G, Furey M, Van Hemelryck S, Biewenga J, Ceusters M, Bhattacharya A, van den 
Boer M, van Nueten L, de Boer P (2018) Clinical pharmacokinetics, pharmacodynamics, safety, and tolerability of JNJ-54175446, a brain permeable P2X7 antagonist, in a randomised singleascending dose study in healthy participants. J Psychopharmacol 32(12):1341-1350. https://doi.org/10.1177/0269881118800067

397. Eser A, Colombel JF, Rutgeerts P, Vermeire S, Vogelsang H, Braddock M, Persson T, Reinisch W (2015) Safety and efficacy of an oral inhibitor of the purinergic receptor P2X7 in adult patients with moderately to severely active Crohn's disease: a randomized placebo-controlled, double-blind, phase iia study. Inflamm Bowel Dis 21(10):2247-2253. https://doi.org/10.1097/ mib.0000000000000514

398. Shakweh M, Ponchel G, Fattal E (2004) Particle uptake by Peyer's patches: a pathway for drug and vaccine delivery. Expert Opin Drug Deliv 1(1):141-163. https://doi.org/10.1517/17425247.1.1. 141

399. Zgair A, Wong JCM, Gershkovich P (2016) Targeting immunomodulatory agents to the gut-associated lymphoid tissue. NeuroImmuno-Gastroenterology:237-261. https://doi.org/10.1007/9783-319-28609-9 14

400. Trevaskis NL, Charman WN, Porter CJ (2008)Lipid-based delivery systems and intestinal lymphatic drug transport: a mechanistic update. Adv Drug Deliv Rev 60(6):702-716. https://doi.org/10. 1016/j.addr.2007.09.007

401. Trevaskis NL, Charman WN, Porter CJ (2010) Targeted drug delivery to lymphocytes: a route to site-specific immunomodulation? Mol Pharm 7(6):2297-2309. https://doi. org $/ 10.1021 / \mathrm{mp} 100259 \mathrm{a}$

402. Hsu YW, Somma J, Newman MF, Mathew JP (2011) Population pharmacokinetics of lidocaine administered during and after cardiac surgery. J Cardiothorac Vasc Anesth 25(6):931-936. https:// doi.org/10.1053/j.jvca.2011.03.008

403. Mori K, Ito H, Toda Y, Hashimoto T, Miyazaki M, Saijo T, Kuroda Y (2004) Successful management of intractable epilepsy with lidocaine tapes and continuous subcutaneous lidocaine infusion. Epilepsia 45(10):1287-1290. https://doi.org/10.1111/j. 0013-9580.2004.17304.x

404. Ranieri VM, Rubenfeld GD, Thompson BT, Ferguson ND, Caldwell E, Fan E, Camporota L, Slutsky AS (2012) Acute respiratory distress syndrome: the Berlin Definition. Jama 307(23): 2526-2533. https://doi.org/10.1001/jama.2012.5669

405. Wang J, Zheng P, Huang Z, Huang H, Xue M, Liao C, Sun B, Zhong N (2020) Serum SP-A and KL-6 levels can predict the improvement and deterioration of patients with interstitial pneumonia with autoimmune features. BMC Pulm Med 20(1):315. https://doi.org/10.1186/s12890-020-01336-y

406. Mallapaty S (2020) The coronavirus is most deadly if you are older and male - new data reveal the risks. Nature 585(7823): 16-17. https://doi.org/10.1038/d41586-020-02483-2

407. Izcovich A, Ragusa MA, Tortosa F, Lavena Marzio MA, Agnoletti C, Bengolea A, Ceirano A, Espinosa F, Saavedra E, Sanguine V, Tassara A, Cid C, Catalano HN, Agarwal A, Foroutan F, Rada G (2020) Prognostic factors for severity and mortality in patients infected with COVID-19: A systematic review. PLoS One 15(11):e0241955. https://doi.org/10.1371/ journal.pone. 0241955

408. Diaz-Vera M, Terrones Santa Cruz J, Forttini Headrington A, Cerna Paz JA, Quintanilla Rios L, Medina Melendez MP, Del Águila Torres J (2020) Lidocaine to reduce the severity of covid-19 cases. Therapia Neural. Sabadell. Barcelona, Spain. http://www.terapianeural.com/articulos/28-studies-estudios/495lidocaine-to-reduce-the-severity-of-covid-19-cases. Accessed 19112020

409. Muller M, Lefebvre F, Harlay ML, Glady L, Becker G, Muller C, Aberkane O, Tawk M, Julians M, Romoli A, Hecketsweiler S, Schneider F, Pottecher J, Chamaraux-Tran TN (2021) Impact of intravenous lidocaine on clinical outcomes of patients with ARDS during COVID-19 pandemia (LidoCovid): a structured summary of a study protocol for a randomised controlled trial. Trials 22(1): 131. https://doi.org/10.1186/s13063-021-05095-x

410. Bharat A, Querrey M, Markov NS, Kim S, Kurihara C, GarzaCastillon R, Manerikar A, Shilatifard A, Tomic R, Politanska Y, Abdala-Valencia H, Yeldandi AV, Lomasney JW, Misharin AV, Budinger GRS (2020) Lung transplantation for patients with severe COVID-19. Sci Transl Med. https://doi.org/10.1126/ scitranslmed.abe 4282

411. Gordh T (2010) Lidocaine: the origin of a modern local anesthetic. 1949. Anesthesiology 113(6):1433-1437. https://doi.org/10.1097/ ALN.0b013e3181fcef 48

412. Derry S, Wiffen PJ, Moore RA, Quinlan J (2014) Topical lidocaine for neuropathic pain in adults. Cochrane Database Syst Rev 2014(7):CD010958. https://doi.org/10.1002/14651858. CD010958.pub2

413. Beaussier M, Delbos A, Maurice-Szamburski A, Ecoffey C, Mercadal L (2018) Perioperative use of intravenous lidocaine. Drugs 78(12):1229-1246. https://doi.org/10.1007/s40265-0180955-x

414. Su D, Gu Y, Wang Z, Wang X (2010) Lidocaine attenuates proinflammatory cytokine production induced by extracellular adenosine triphosphate in cultured rat microglia. Anesth Analg 111(3): 768-774. https://doi.org/10.1213/ANE.0b013e3181e9e897

415. Yuan T, Li Z, Li X, Yu G, Wang N, Yang X (2014) Lidocaine attenuates lipopolysaccharide-induced inflammatory responses in microglia. J Surg Res 192(1):150-162. https://doi.org/10.1016/j. jss.2014.05.023

416. Flondor M, Listle H, Kemming GI, Zwissler B, Hofstetter C (2010) Effect of inhaled and intravenous lidocaine on inflammatory reaction in endotoxaemic rats. Eur J Anaesthesiol 27(1):5360. https://doi.org/10.1097/EJA.0b013e32832b8a70

417. Chen LJ, Ding YB, Ma PL, Jiang SH, Li KZ, Li AZ, Li MC, Shi CX, Du J, Zhou HD (2018) The protective effect of lidocaine on lipopolysaccharide-induced acute lung injury in rats through NF$\mathrm{KB}$ and p38 MAPK signaling pathway and excessive inflammatory responses. Eur Rev Med Pharmacol Sci 22(7):2099-2108. https://doi.org/10.26355/eurrev 20180414743

418. Feng G, Liu S, Wang G-L, Liu G-J(2008) Lidocaine attenuates lipopolysaccharide-induced acute lung injury through inhibiting NF-kappaB activation. Pharmacology 81(1):32-40. https://doi. org/10.1159/000107792

419. Huang TK, Uyehara CF, Balaraman V, Miyasato CY, Person D, Egan E, Easa D (2004) Surfactant lavage with lidocaine improves pulmonary function in piglets after $\mathrm{HCl}$-induced acute lung injury. Lung 182(1):15-25. https://doi.org/10.1007/s00408-003-1041-y

420. Kiyonari Y, Nishina K, Mikawa K, Maekawa N, Obara H (2000) Lidocaine attenuates acute lung injury induced by a combination of phospholipase A2 and trypsin. Crit Care Med 28(2):484-489. https://doi.org/10.1097/00003246-200002000-00033

421. Pedersen JL, Callesen T, Møiniche S, Kehlet H (1996) Analgesic and anti-inflammatory effects of lignocaine-prilocaine(EMLA) cream in human burn injury. Br J Anaesth 76(6):806-810. https://doi.org/10.1093/bja/76.6.806

422. Werner RM, Hoffman AK, Coe NB (2020)Long-term care policy after Covid-19 - solving the nursing home crisis. N Engl J Med 383(10):903-905. https://doi.org/10.1056/NEJMp2014811

423. Lesch CA, Squier CA, Cruchley A, Williams DM, Speight P (1989) The permeability of human oral mucosa and skin to water. J Dent Res 68(9):1345-1349. https://doi.org/10.1177/ 00220345890680091101

424. Goyal AK, Singh R, Chauhan G, Rath G (2018)Non-invasive systemic drug delivery through mucosal routes. Artif Cells Nanomed Biotechnol 46(sup2):539-551. https://doi.org/10.1080/ 21691401.2018.1463230 
425. Gröningsson K, Lindgren JE, Lundberg E, Sandberg R, Wahlén A (1985) Lidocaine base and hydrochloride. In: Florey K (ed) Analytical profiles of drug substances, vol 14. Academic Press, pp 207-243. https://doi.org/10.1016/S0099-5428(08)60582-1

426. Charman WNA, Stella VJ (1986) Estimating the maximal potential for intestinal lymphatic transport of lipophilic drug molecules. Int J Pharm 34(1):175-178. https://doi.org/10.1016/03785173(86)90027-X

427. Porter CJ, Trevaskis NL, Charman WN (2007) Lipids and lipidbased formulations: optimizing the oral delivery of lipophilic drugs. Nat Rev Drug Discov 6(3):231-248. https://doi.org/10. $1038 /$ nrd2197

428. Gvetadze SR, Ilkaev KD (2020) Lingual lymph nodes: anatomy, clinical considerations, and oncological significance. World J Clin Oncol 11(6):337-347. https://doi.org/10.5306/wjco.v11.i6.337

429. Ananian SG, Gvetadze SR, Ilkaev KD, Mochalnikova VV, Zayratiants GO, Mkhitarov VA, Yang X, Ciciashvili AM (2015)Anatomic-histologic study of the floor of the mouth: the lingual lymph nodes. Jpn J Clin Oncol 45(6):547-554. https://doi. org/10.1093/jjco/hyv029

430. Fujimura A, Sato Y, Shoji M, Onodera M, Nozaka Y (2007) Lymphatic architecture of the oral region - beneath the buccal mucosa. Microvasc Rev Commun 1(1):9-11. https://doi.org/10. 14532/mvrc. 1.9

431. Ossoff RH, Sisson GA (1981) Lymphatics of the floor of the mouth and neck: anatomical studies related to contralateral drainage pathways. Laryngoscope 91(11):1847-1850. https://doi.org/ 10.1288/00005537-198111000-00008

432. Mohammadi-Samani S, Jamshidzadeh A, Montaseri H, RangbarZahedani M, Kianrad R (2010) The effects of some permeability enhancers on the percutaneous absorption of lidocaine. Pak J Pharm Sci 23(1):83-88

433. Sakdiset P, Kitao Y, Todo H, Sugibayashi K (2017)Highthroughput screening of potential skin penetration-enhancers using stratum corneum lipid liposomes: preliminary evaluation for different concentrations of ethanol. J Pharm (Cairo) 2017: 7409420. https://doi.org/10.1155/2017/7409420
434. Ali Khan A, Mudassir J, Mohtar N, Darwis Y (2013) Advanced drug delivery to the lymphatic system: lipid-based nanoformulations. Int J Nanomedicine 8:2733-2744. https://doi. org/10.2147/ijn.s41521

435. Cho HY, Lee YB (2014)Nano-sized drug delivery systems for lymphatic delivery. J Nanosci Nanotechnol 14(1):868-880. https://doi.org/10.1166/jnn.2014.9122

436. Zhang XY, Lu WY (2014) Recent advances in lymphatic targeted drug delivery system for tumor metastasis. Cancer Biol Med 11(4):247-254. https://doi.org/10.7497/j.issn.2095-3941.2014. 04.003

437. Ahn H, Park JH (2016) Liposomal delivery systems for intestinal lymphatic drug transport. Biomater Res 20:36. https://doi.org/10. 1186/s40824-016-0083-1

Publisher's note Springer Nature remains neutral with regard to jurisdictional claims in published maps and institutional affiliations.

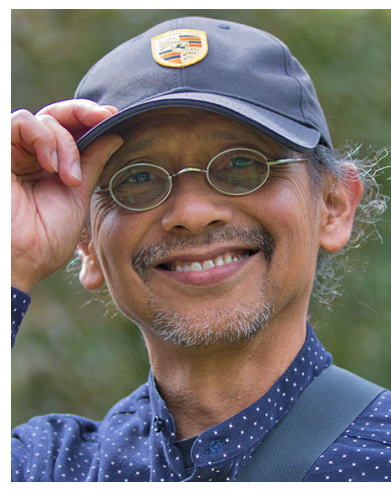

Djo Hasan, MD, PhD is a neurointensivist (ret.) with extensive experience in treating mechanically ventilated patients with ARDS at the Erasmus University Hospital Rotterdam, The Netherlands and immune therapy at the Cell Therapy Clinic in Duderstadt, Germany. He is currently involved in the development of lidocaine as a P2X7R antagonist for the treatment of COVID-19 and other immune-related diseases. 